\title{
An Improved Synthesis of the ABCDE Fragment of Brevetoxin
} A

Michael T. Crimmins,* Patrick J. McDougall, and J. Michael Ellis

Venable and Kenan Laboratories of Chemistry The University of North Carolina at Chapel HillChapel Hill, North Carolina 27599-3290

crimmins@email.unc.edu

\author{
${ }^{1} \mathrm{H}$ and ${ }^{13} \underline{\mathrm{C} N M R}$ Spectra
}




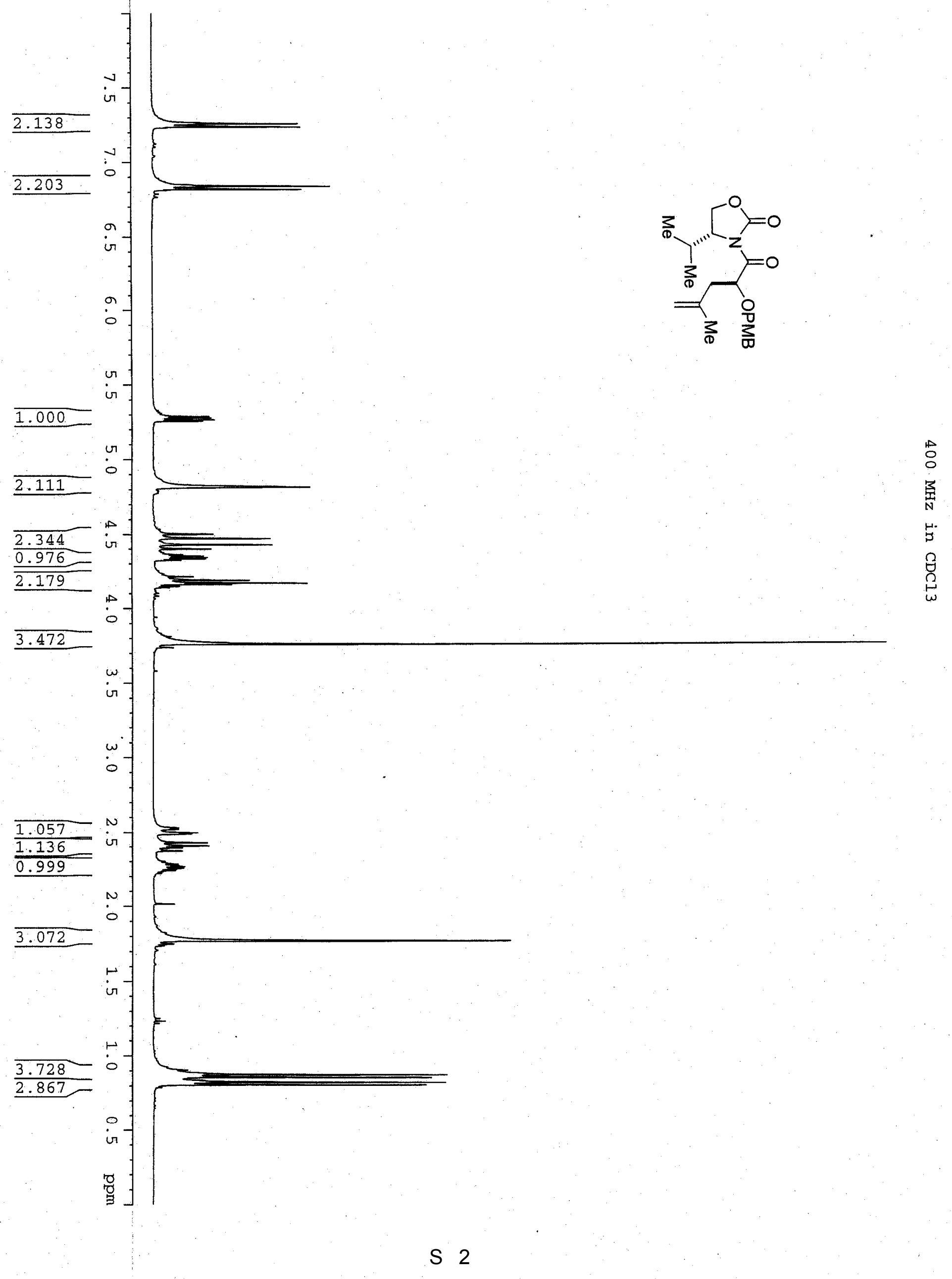




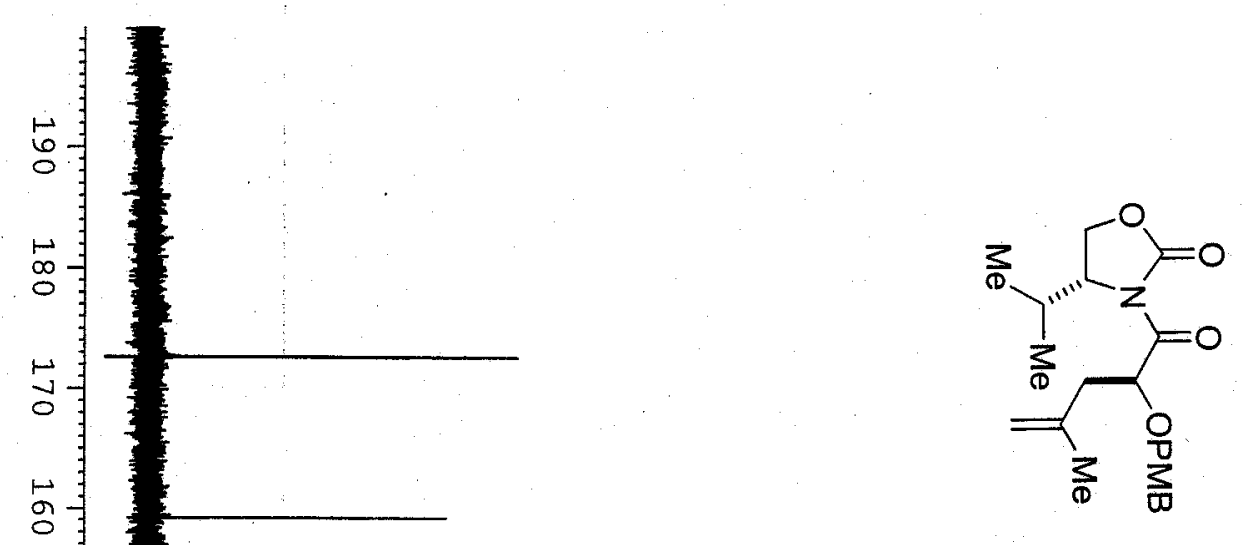

w

占

$\mapsto$
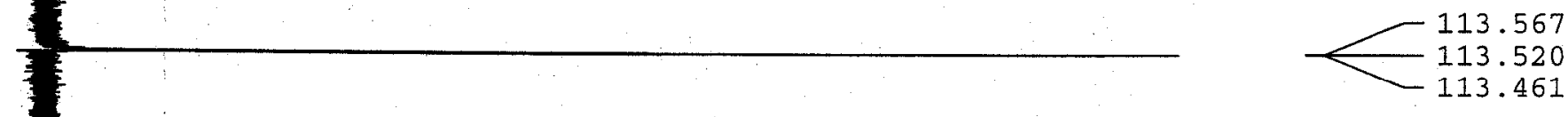

$\stackrel{\circ}{\circ}$

○

$\infty$

วิ

o

年

v

常

w

…

占

兽
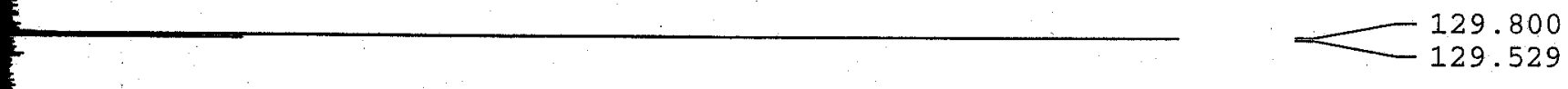

$\stackrel{\circ}{\circ}$

3

$H$.

$\stackrel{8}{8}$

41.023

77.317

76.998

76.679

75.392

$-72.184$

63.771

58.081

55.087

28.272

22.248

17.665

14.651 


\subsection{1}

ir

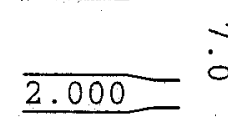

-<smiles>C1=CCC=C1</smiles>

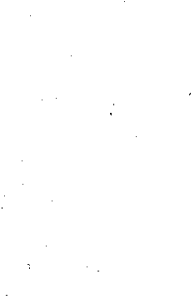$$
\underline{0.207}
$$$$
\frac{0}{2.053} \dot{0}
$$$$
\frac{2.118}{2.037}
$$$$
\frac{0.796}{0.225=0}
$$$$
3.064
$$$$
1.606 \text { ir }
$$$$
\therefore \quad \omega
$$$$
\frac{1}{2.070} \text { ir }
$$$$
2.070
$$
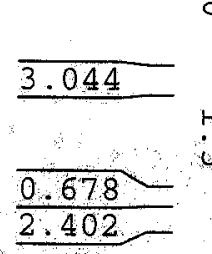

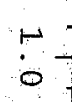$$
\text { ir }
$$

意

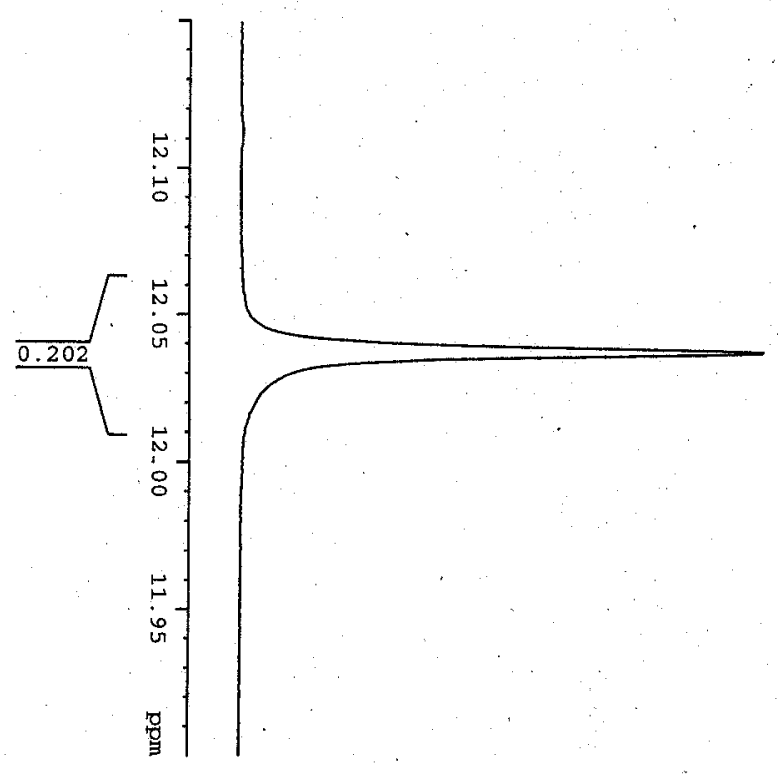




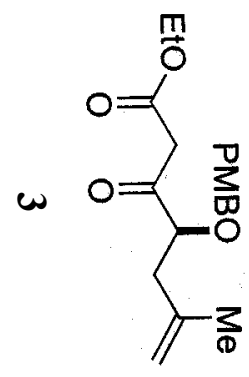

204.975

176.804

172.656

167.154

159.358

159.167

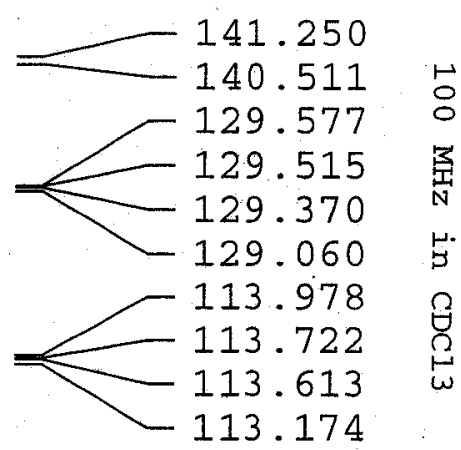

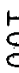

6

$\omega$
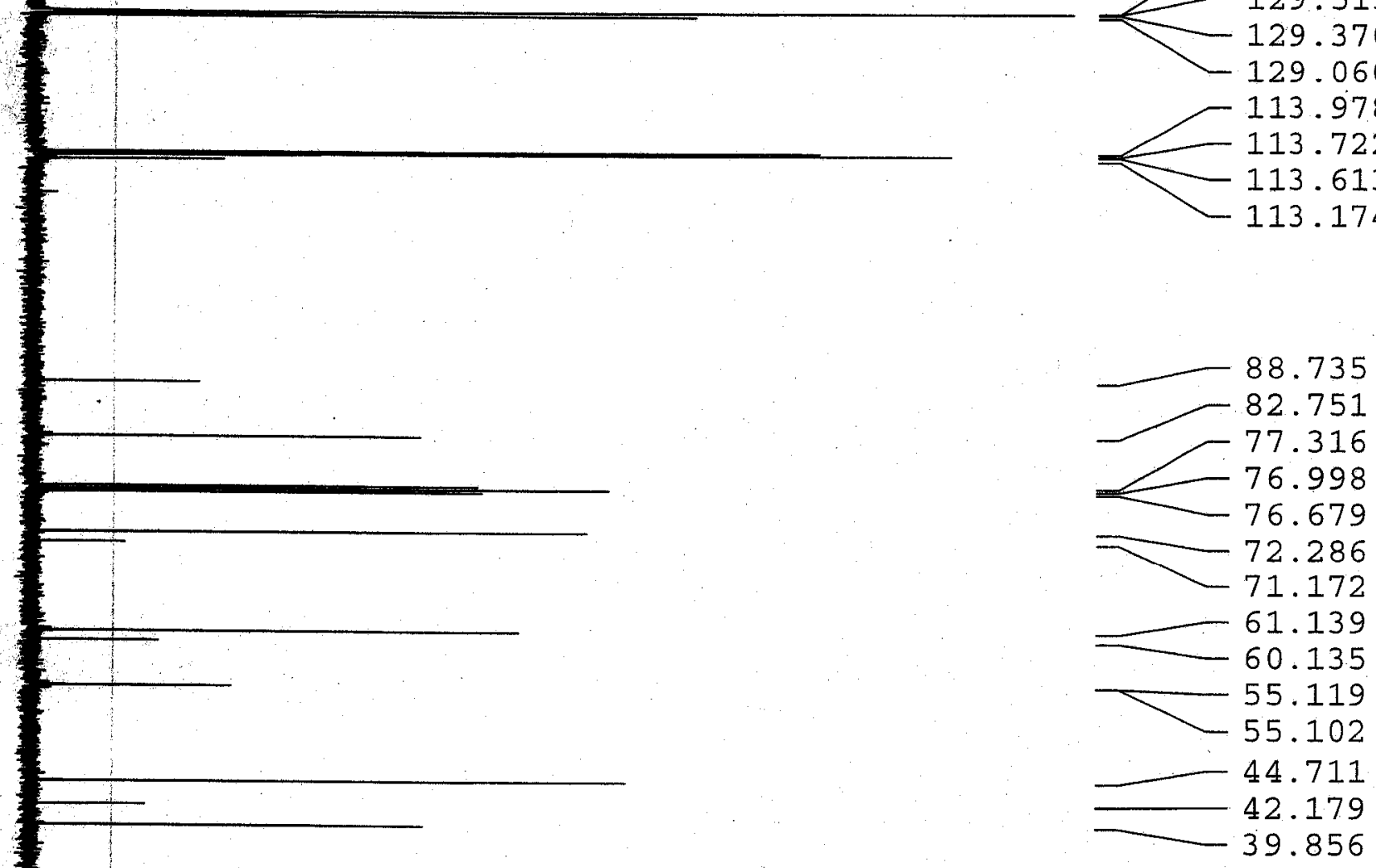

$\omega$

응

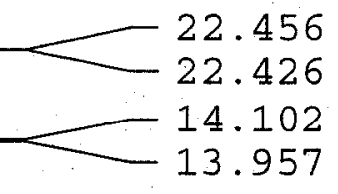




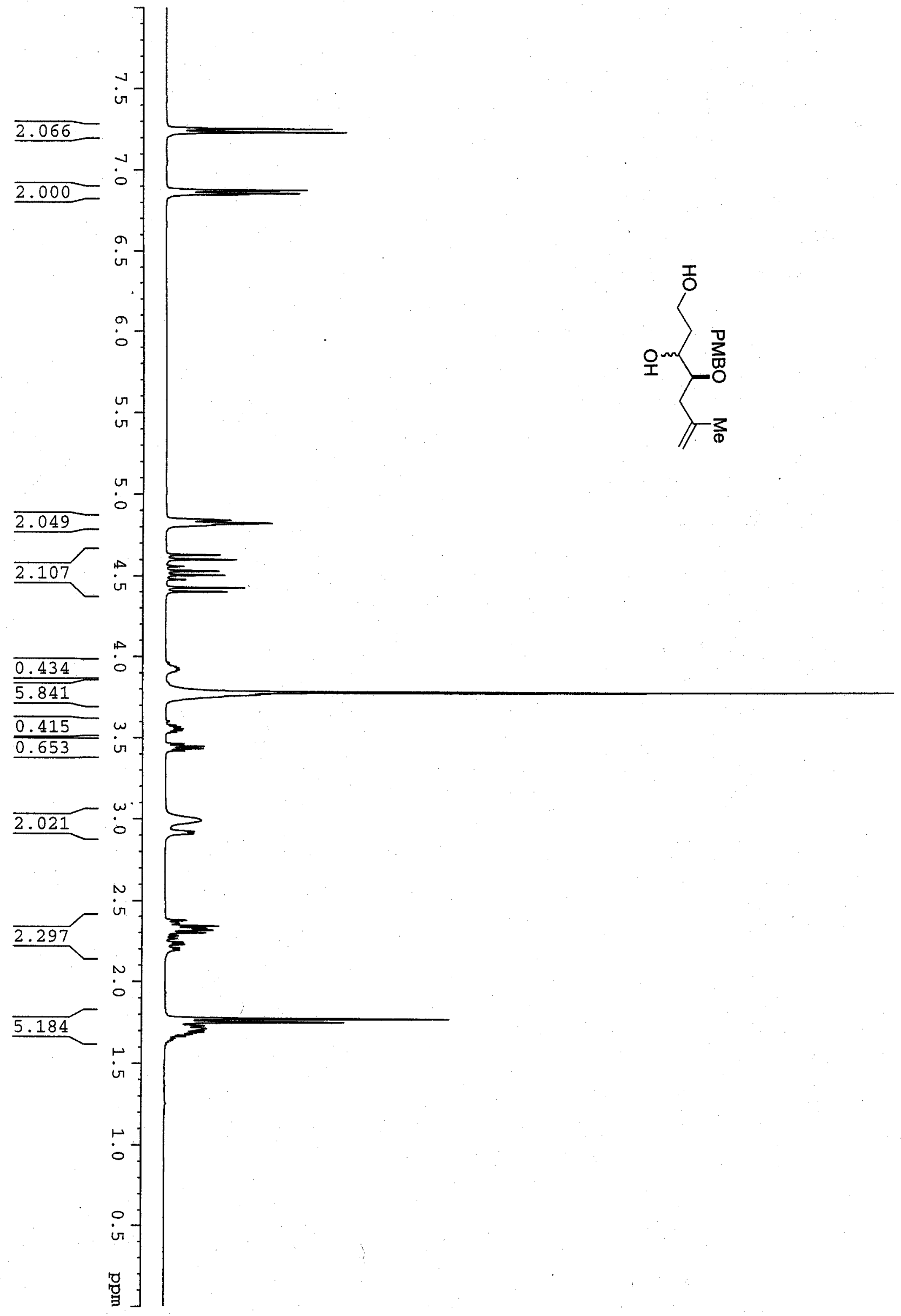



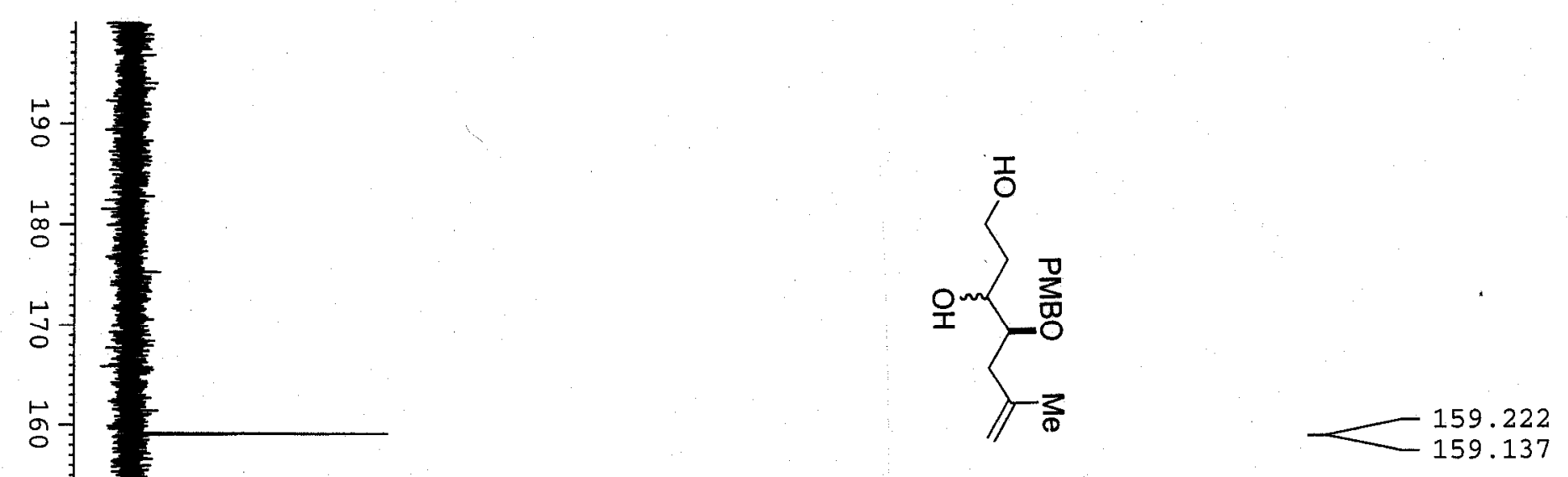

ज

官

ڤ

芩

占

동

0

$\infty$

ㄱ.

o

g

of

$\circ$

里

w

잉

层

莺

142.540
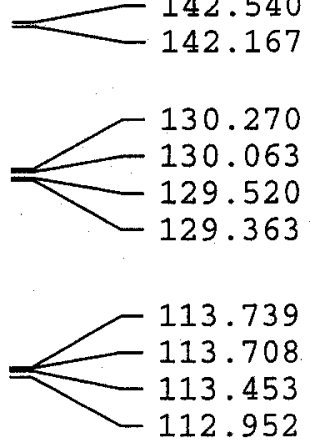

눙

丞

占.

呑
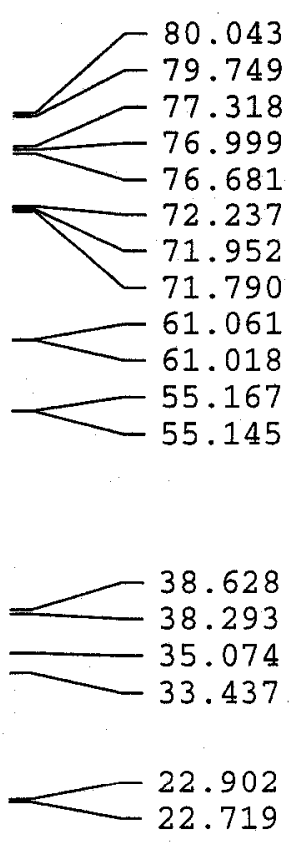


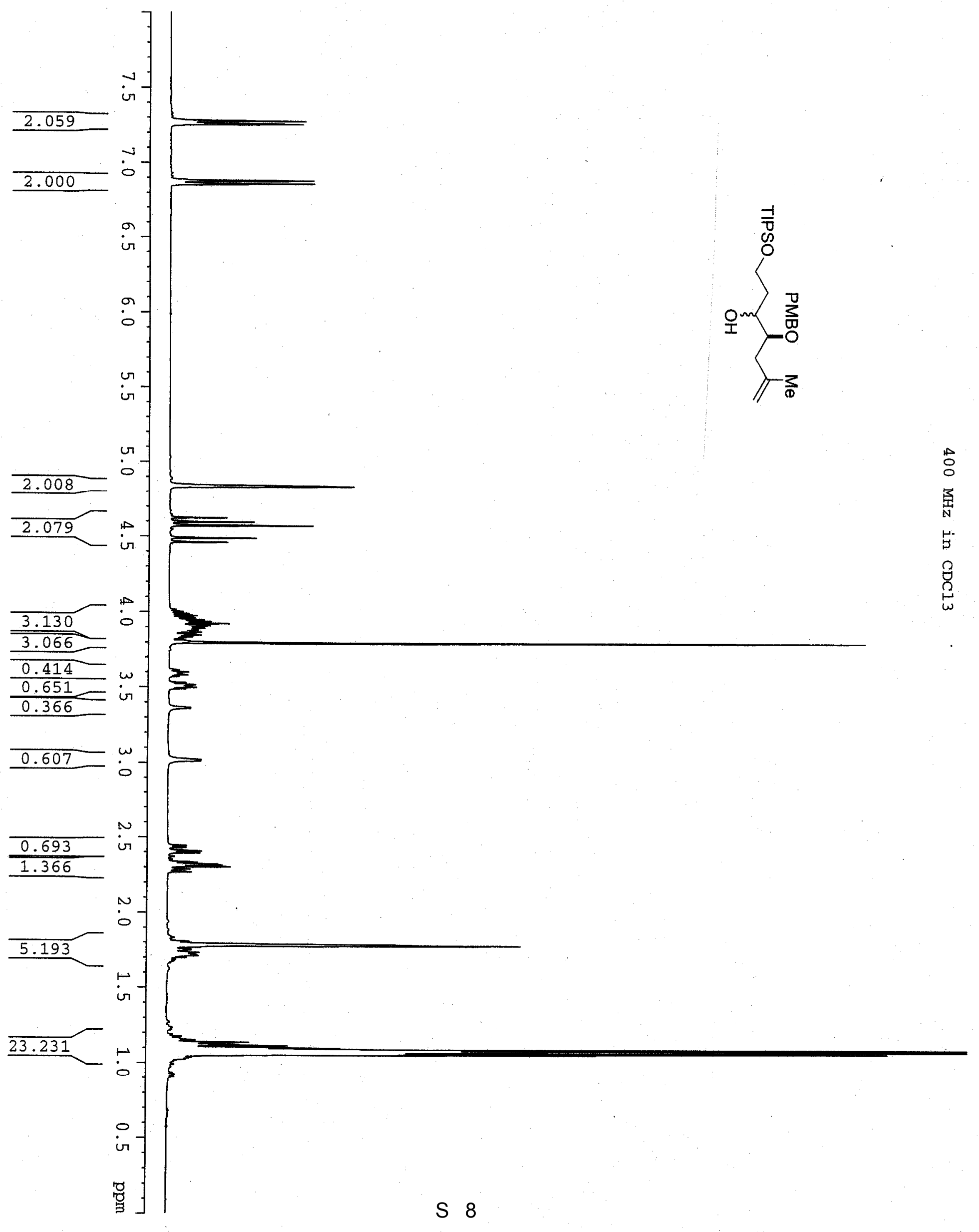



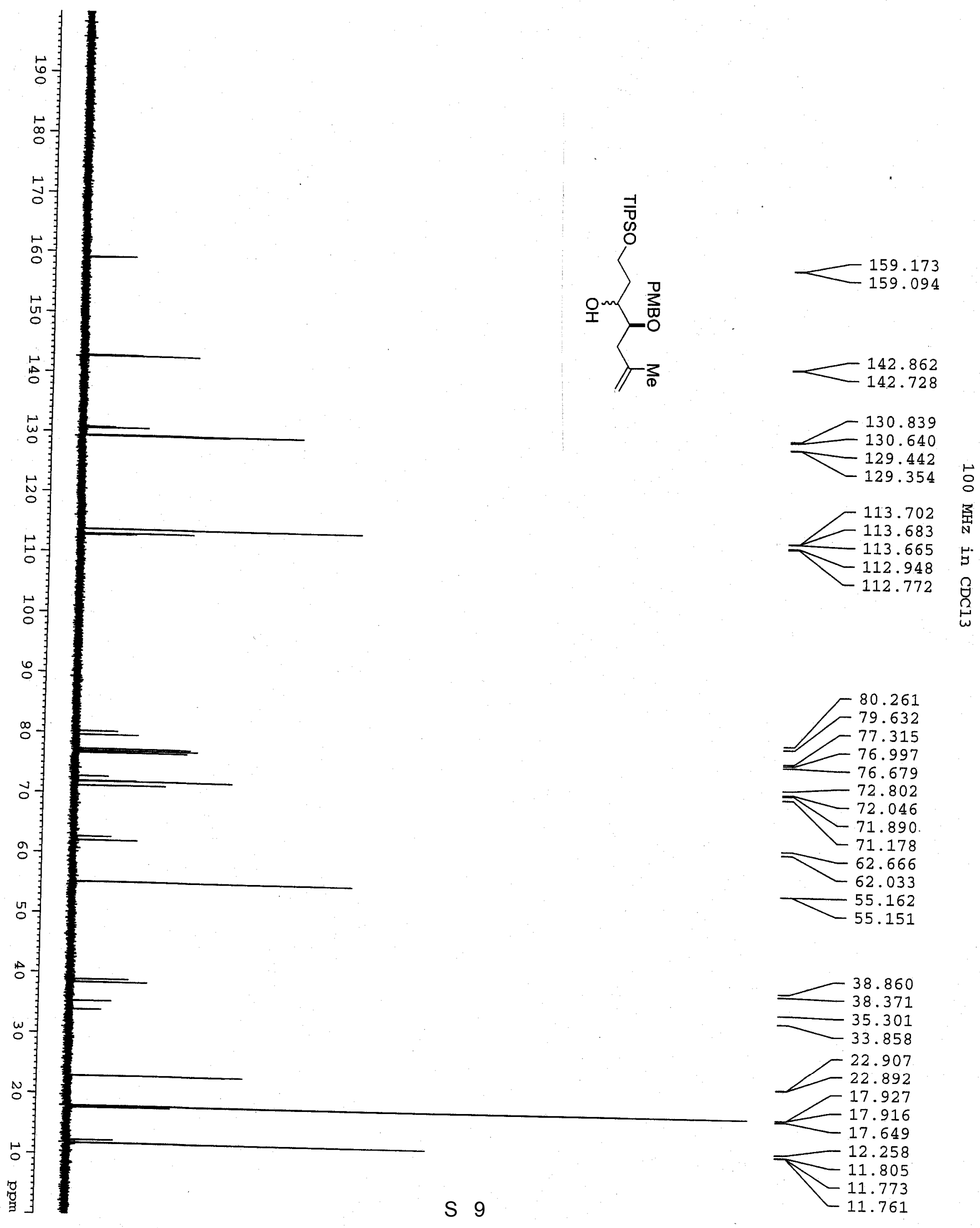


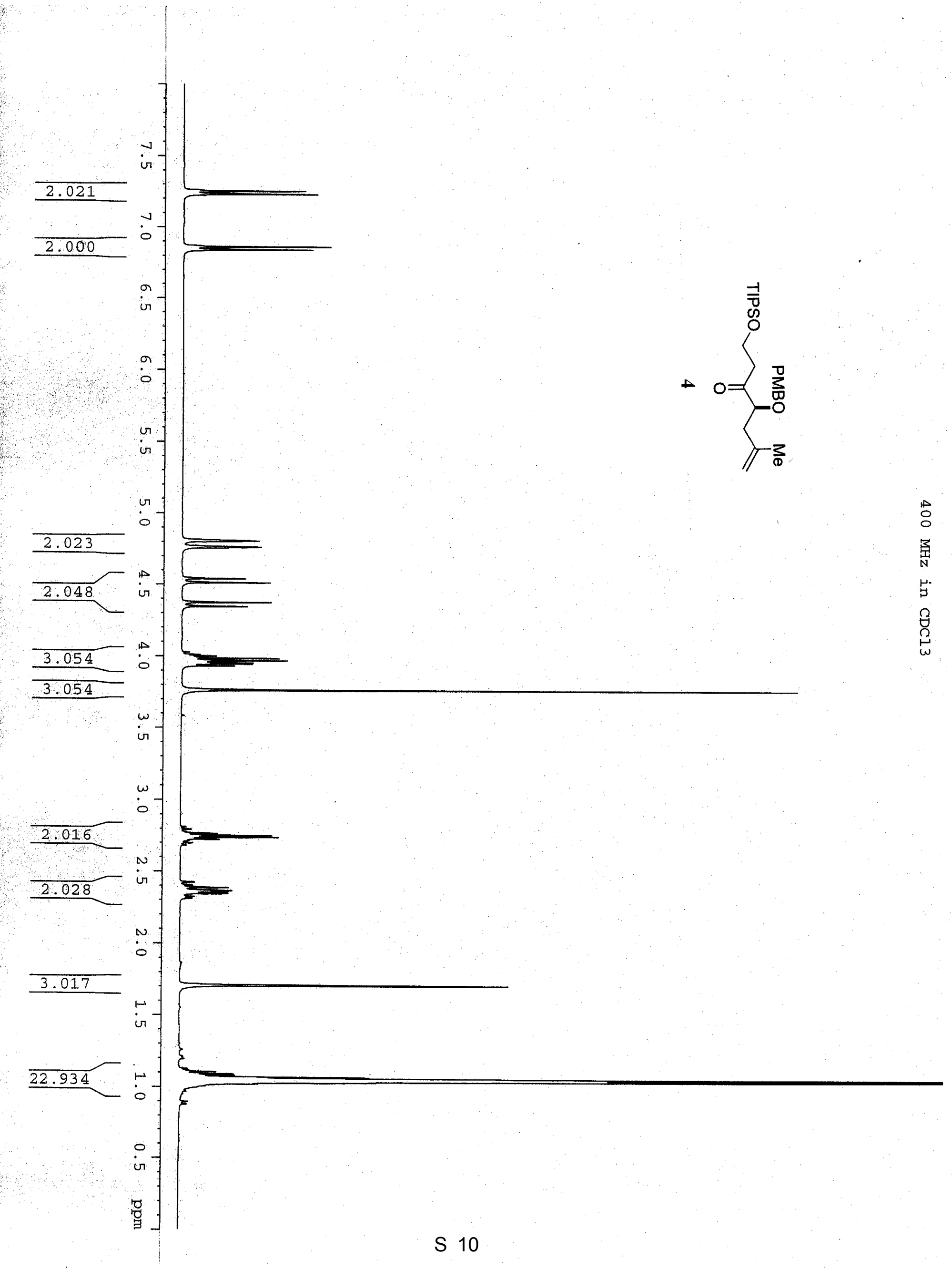




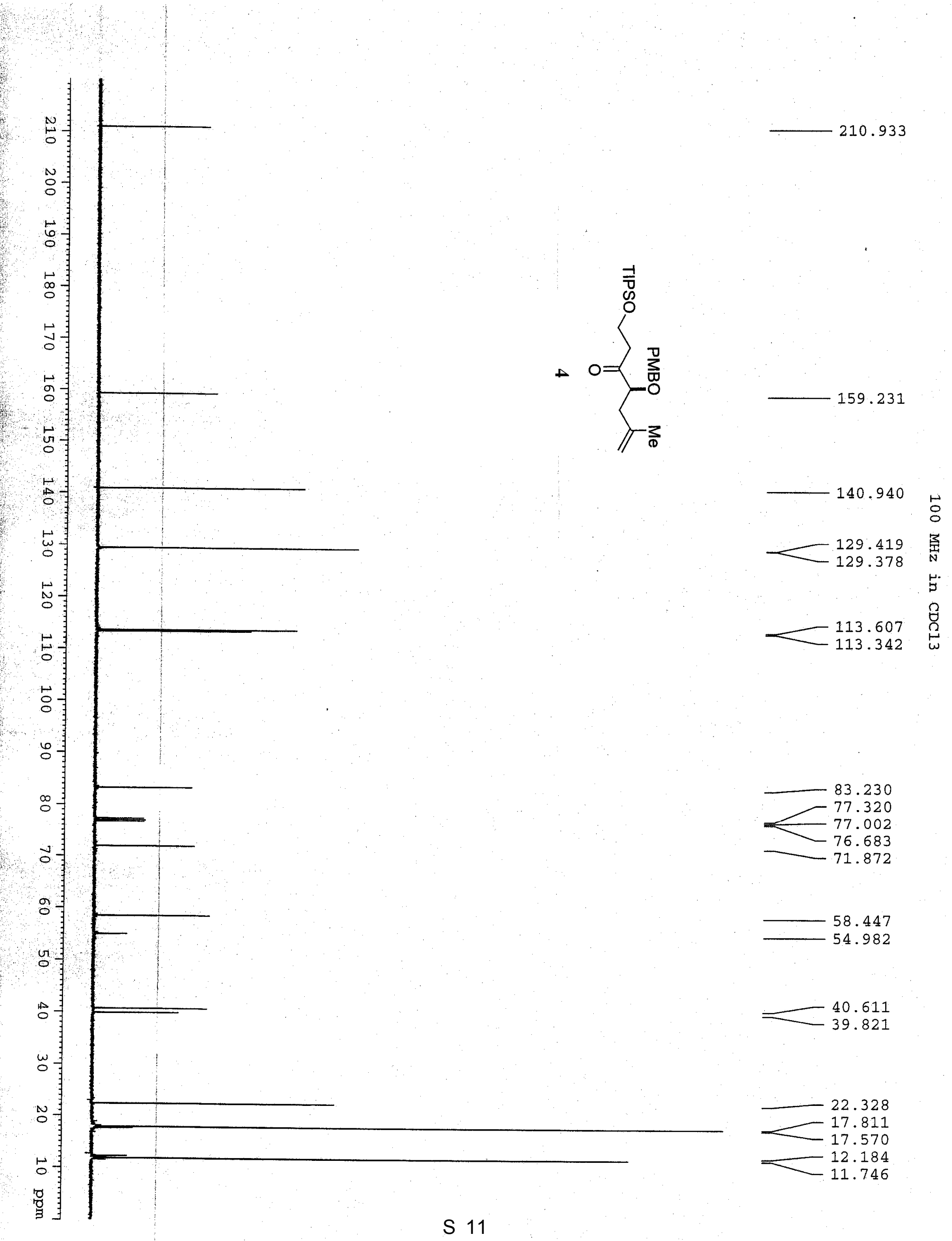




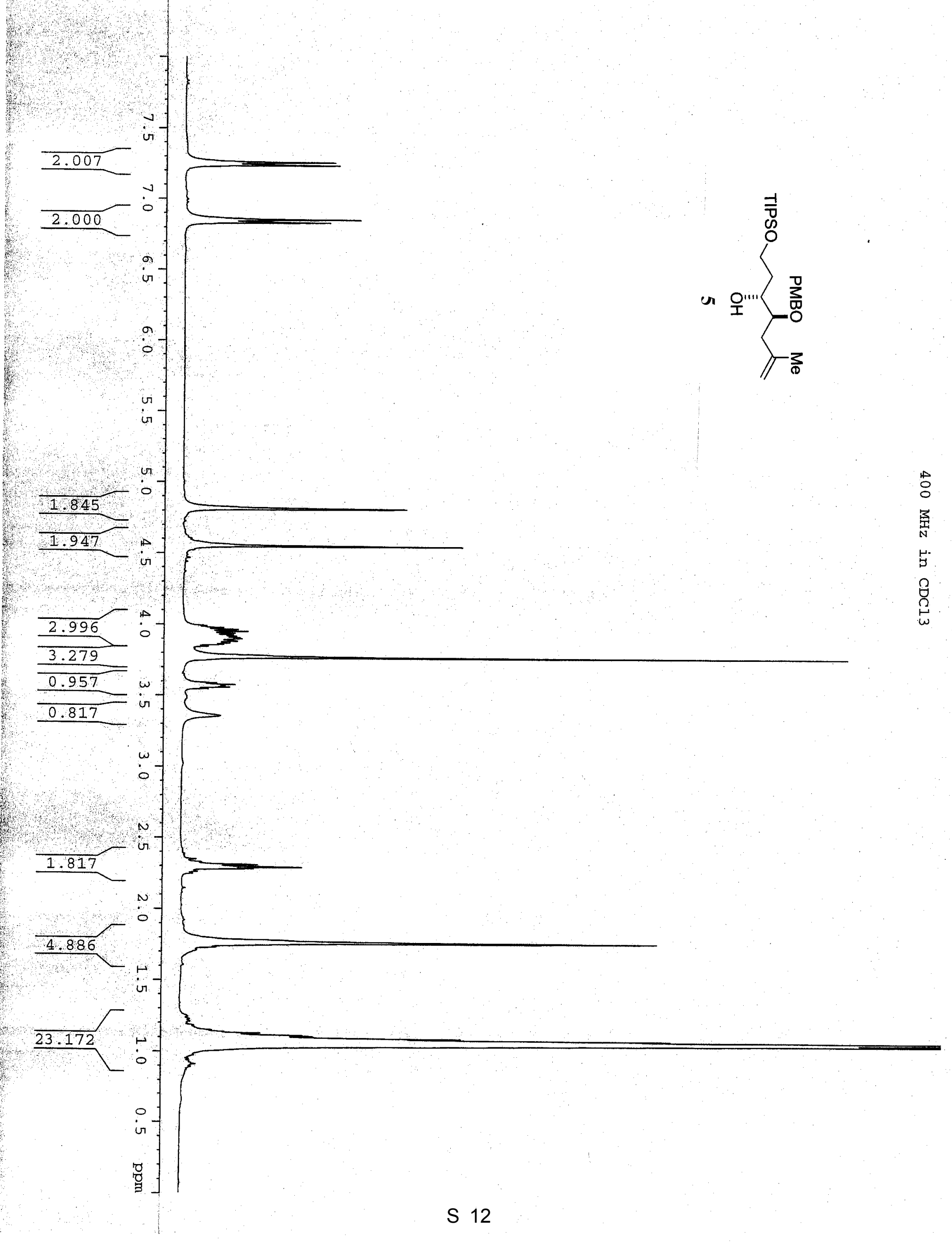



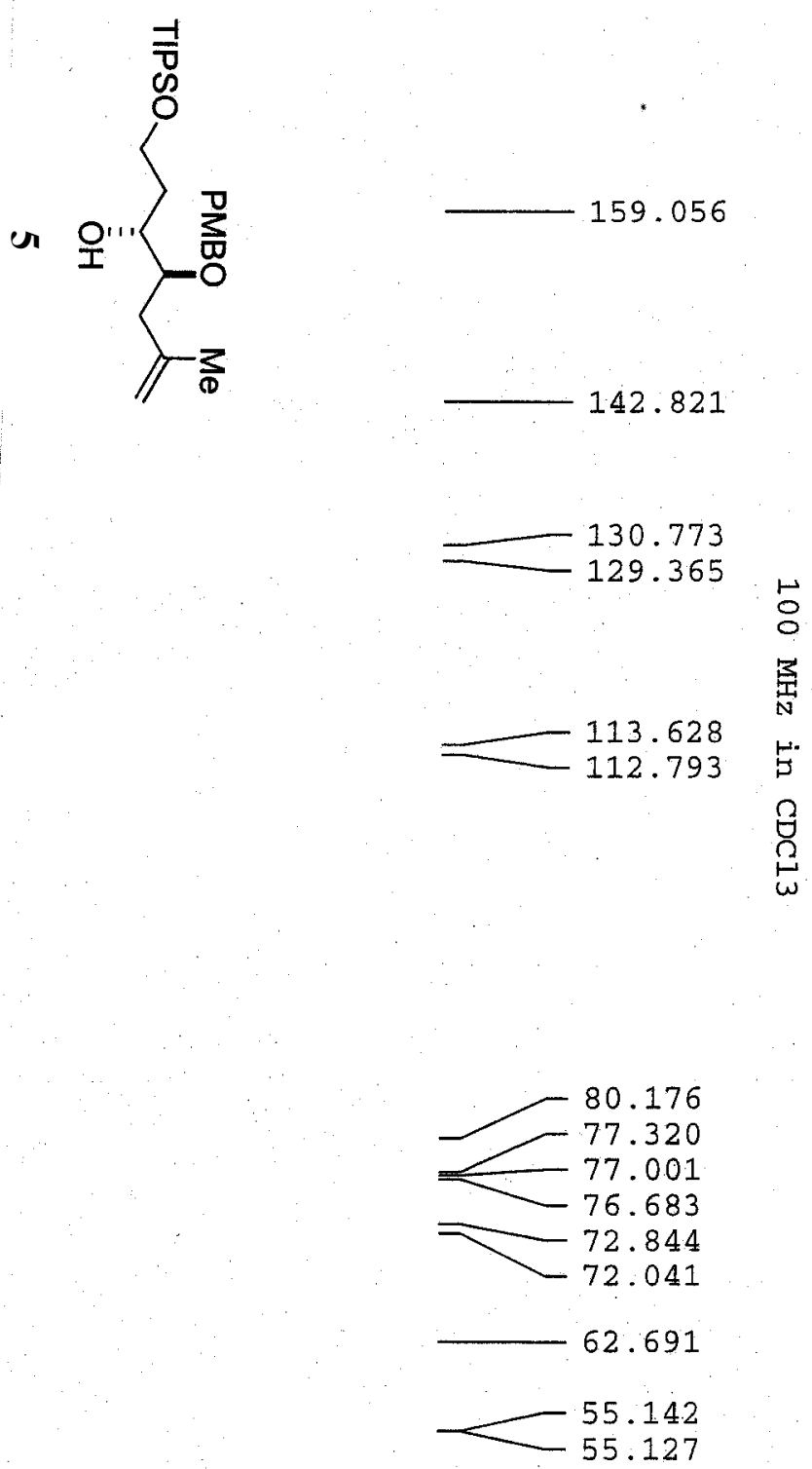

38.851

33.787

$\omega$

N

22.878

17.897

13

O 


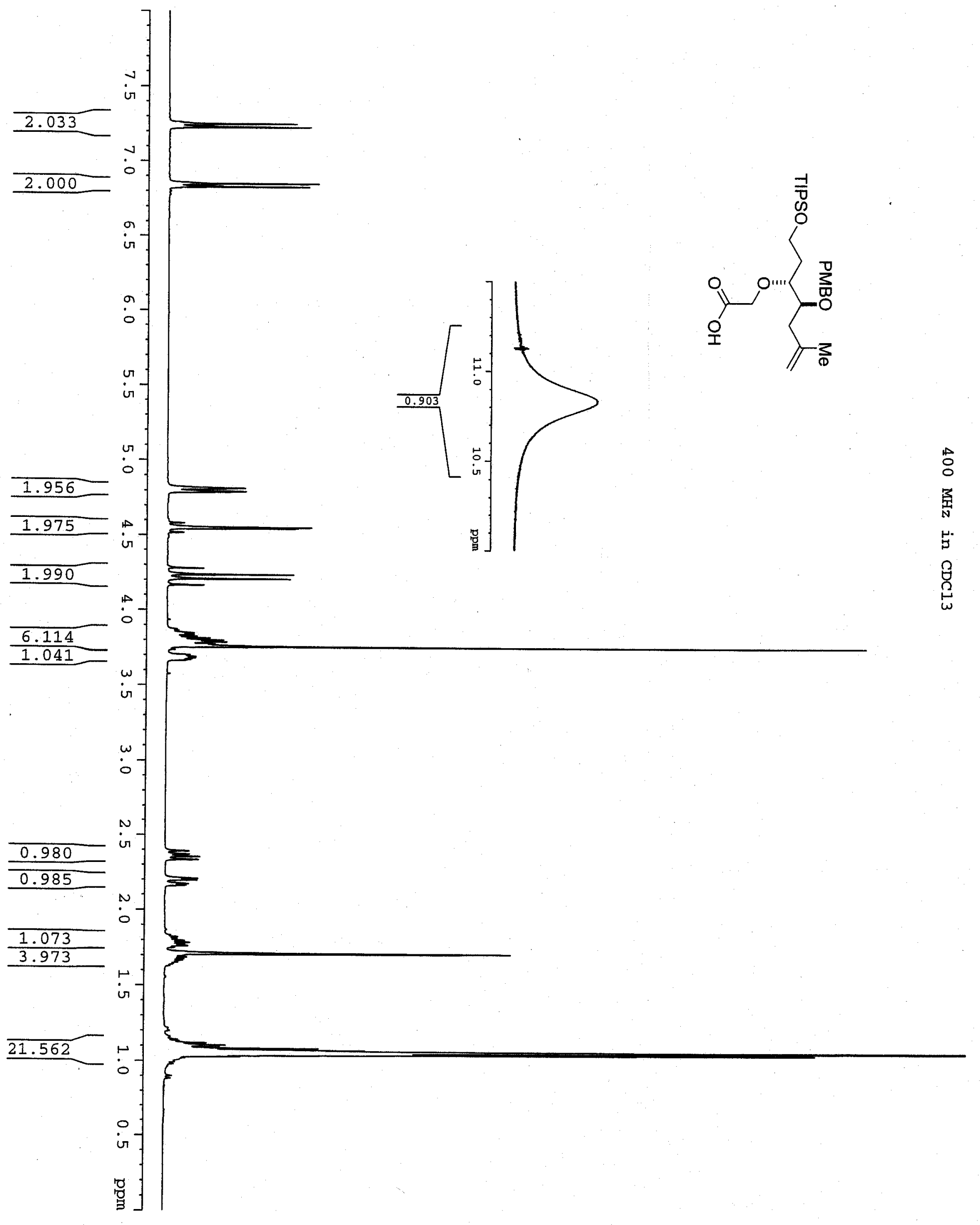



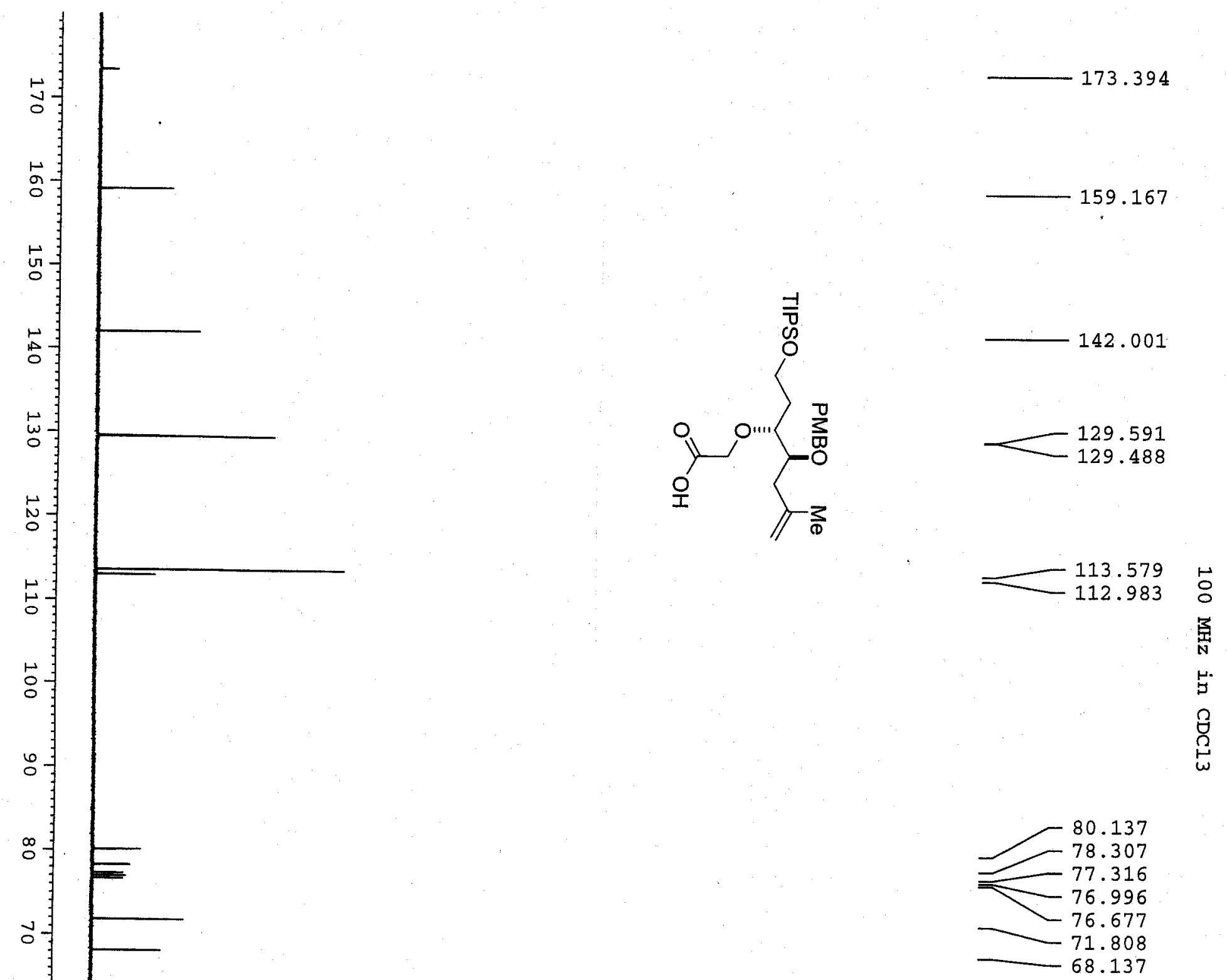

59.598

54.916

38.032 33.635

$\omega$

N

겅

ه
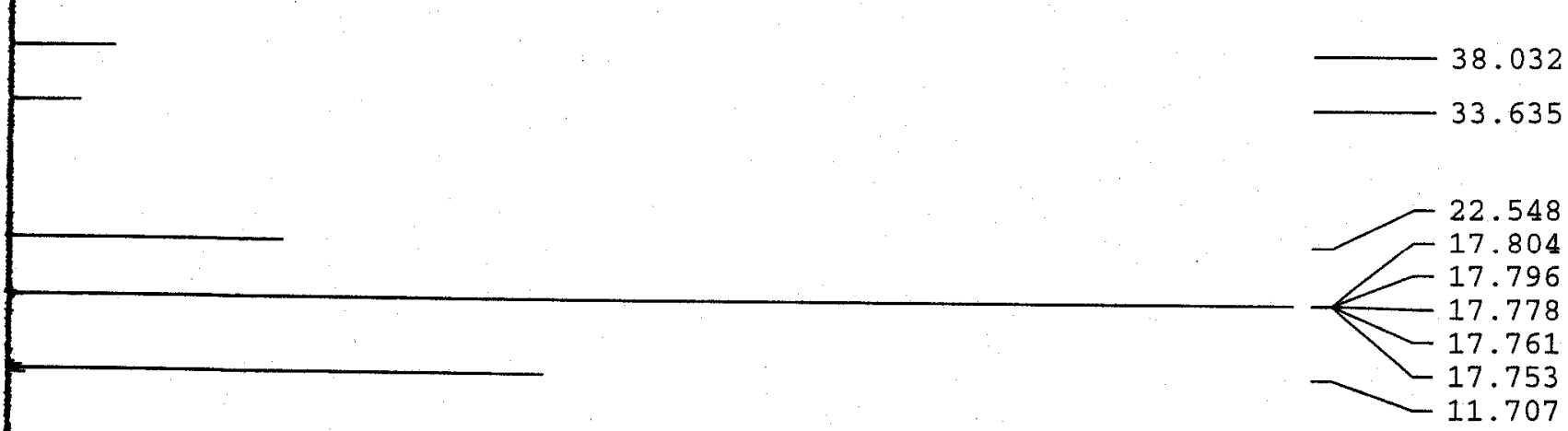

ס 


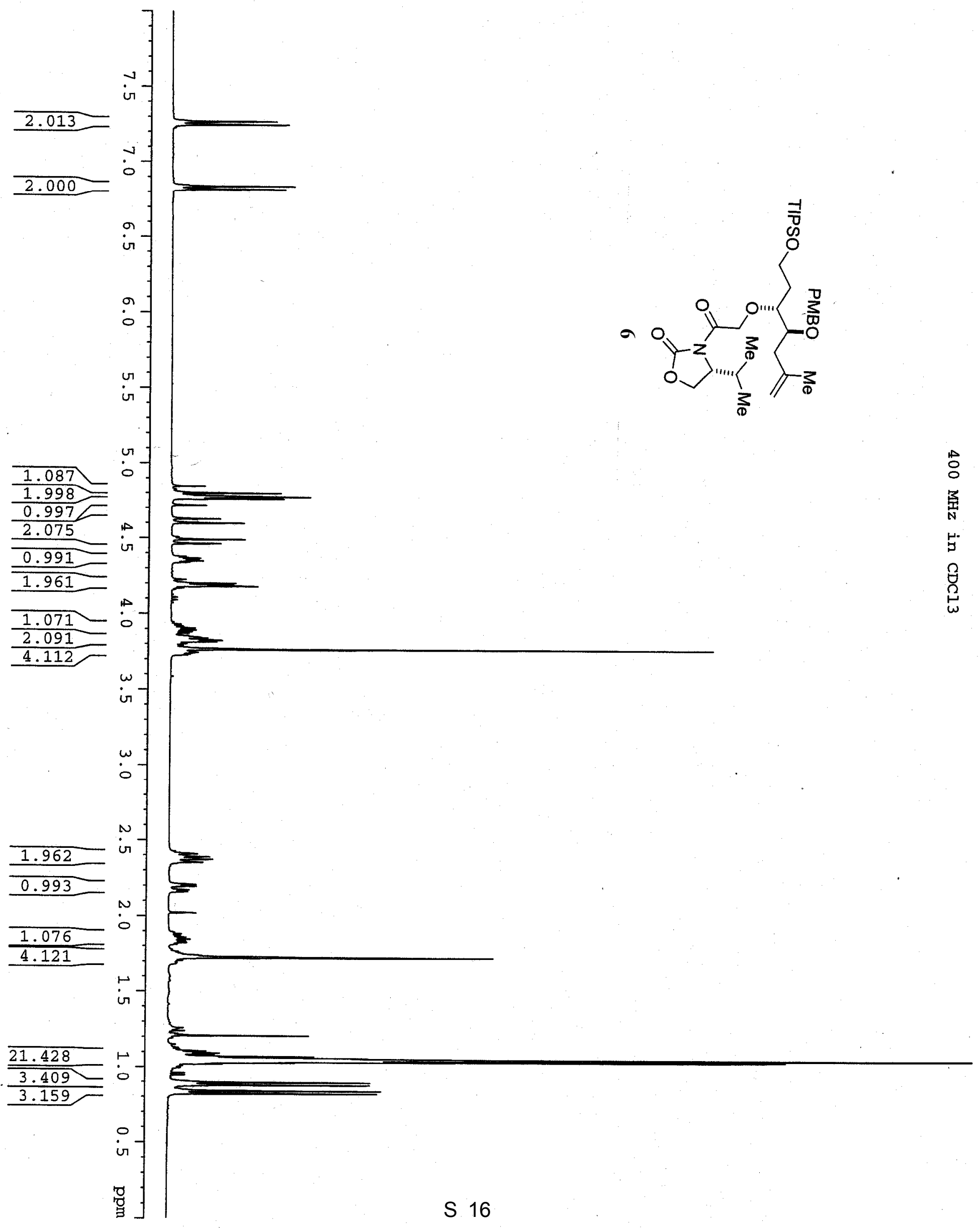



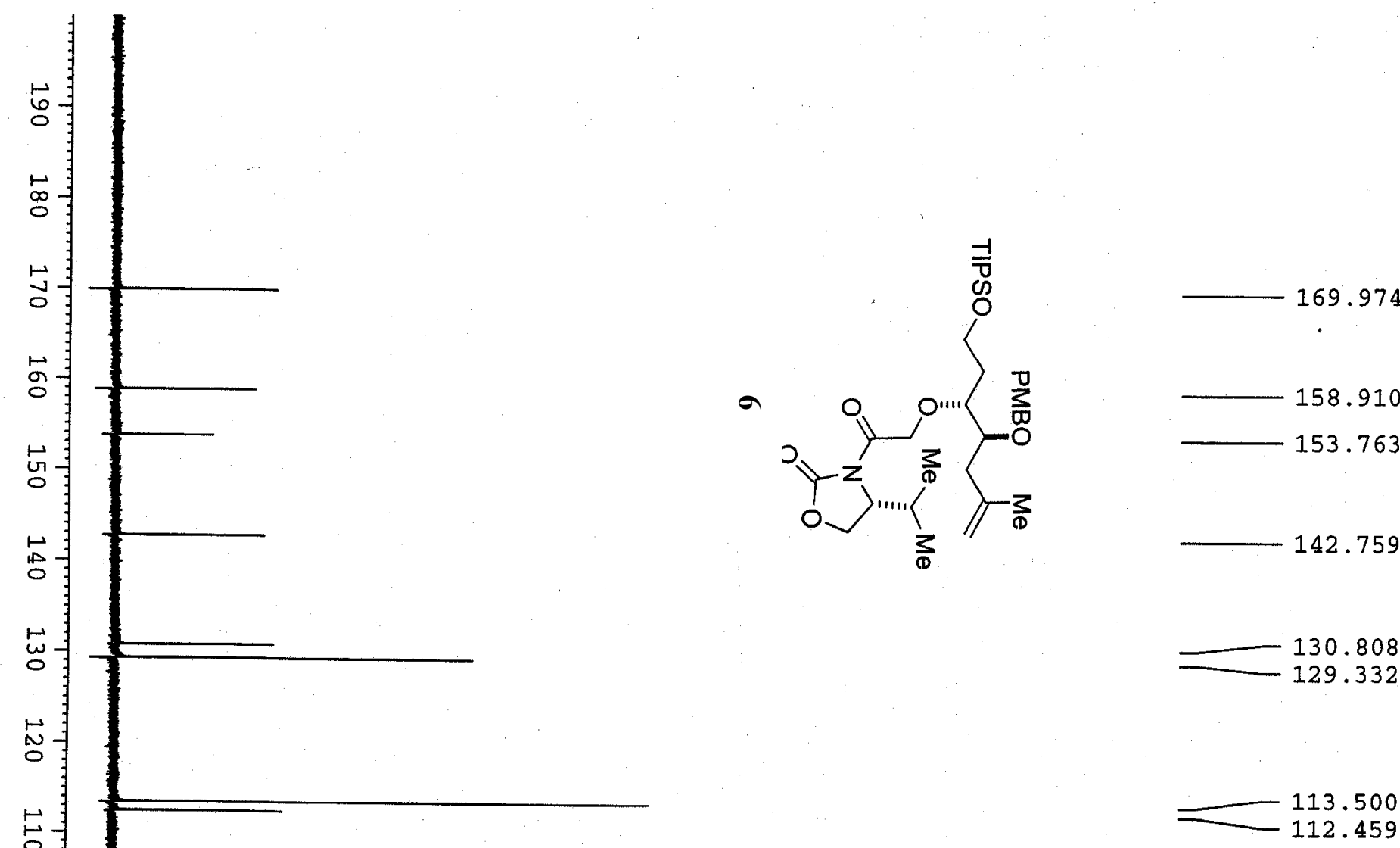

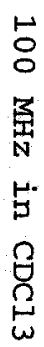

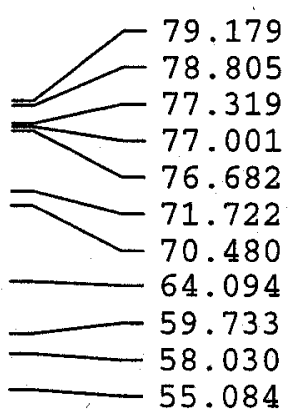

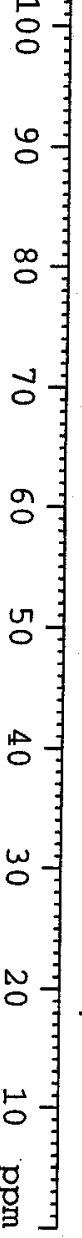

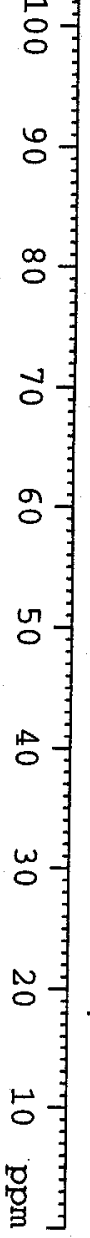

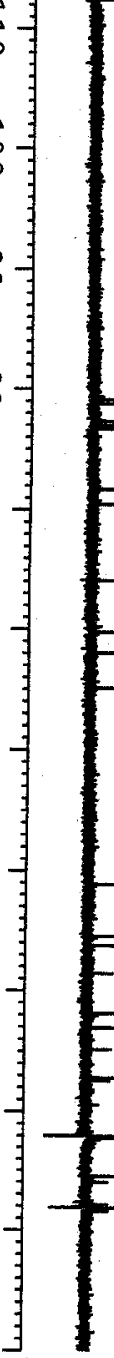

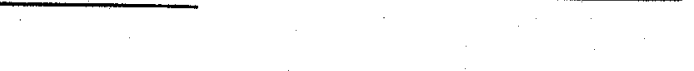

55.084

38.873

33.762

$-28.132$

26.919

22.755

$-17.919$

$-17.913$

$\leftarrow 17.897$

$\longrightarrow 17.737$

14.474 


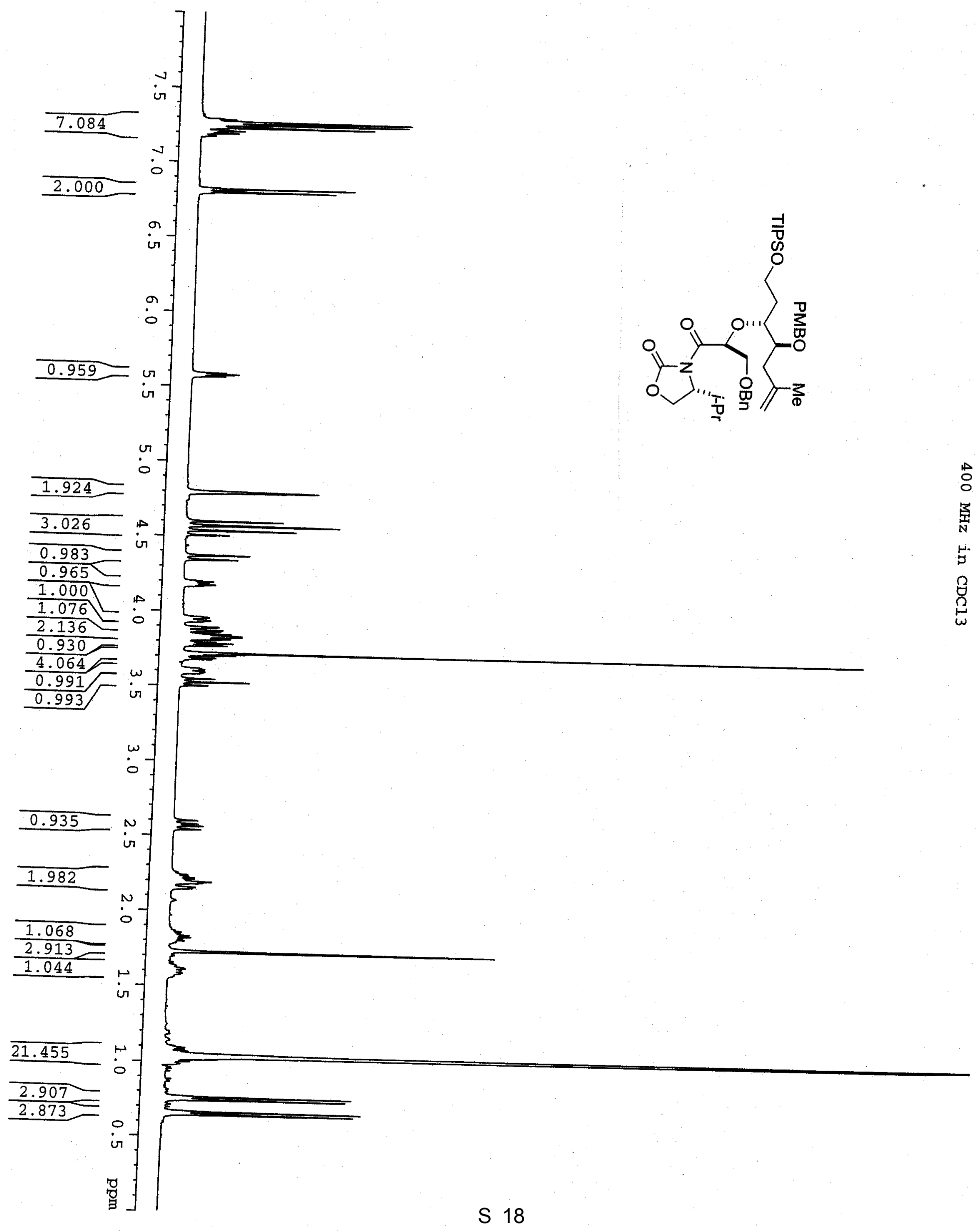



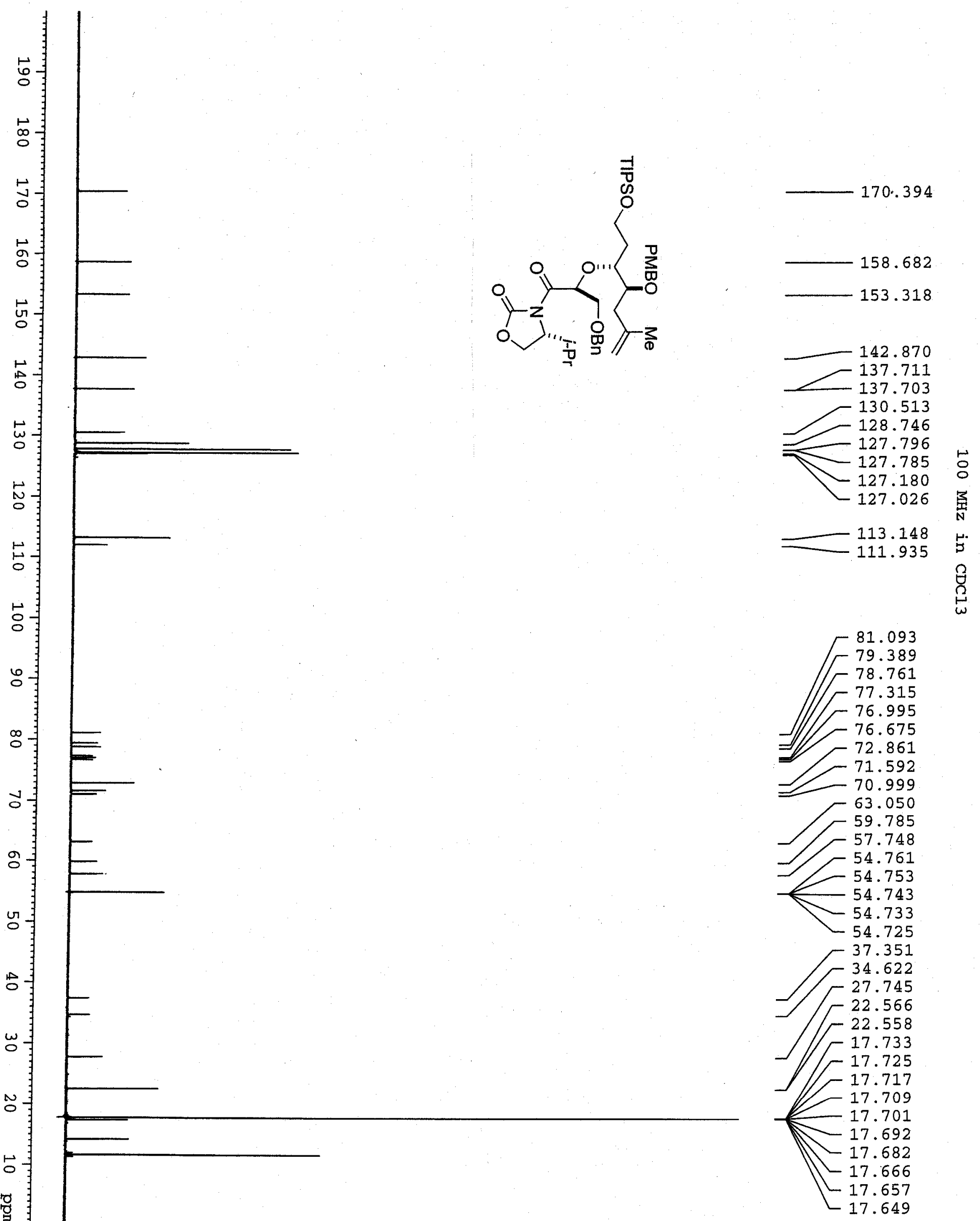


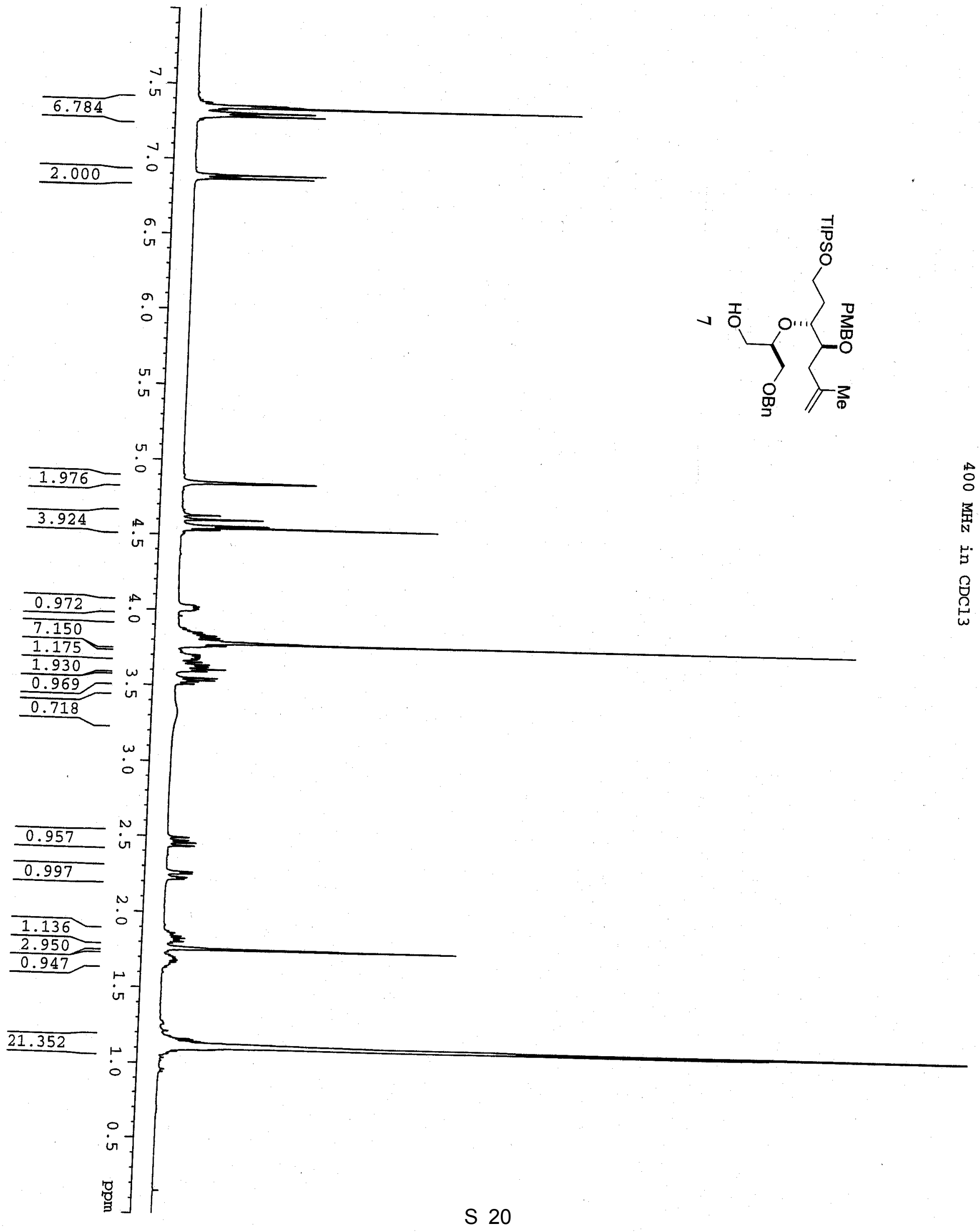



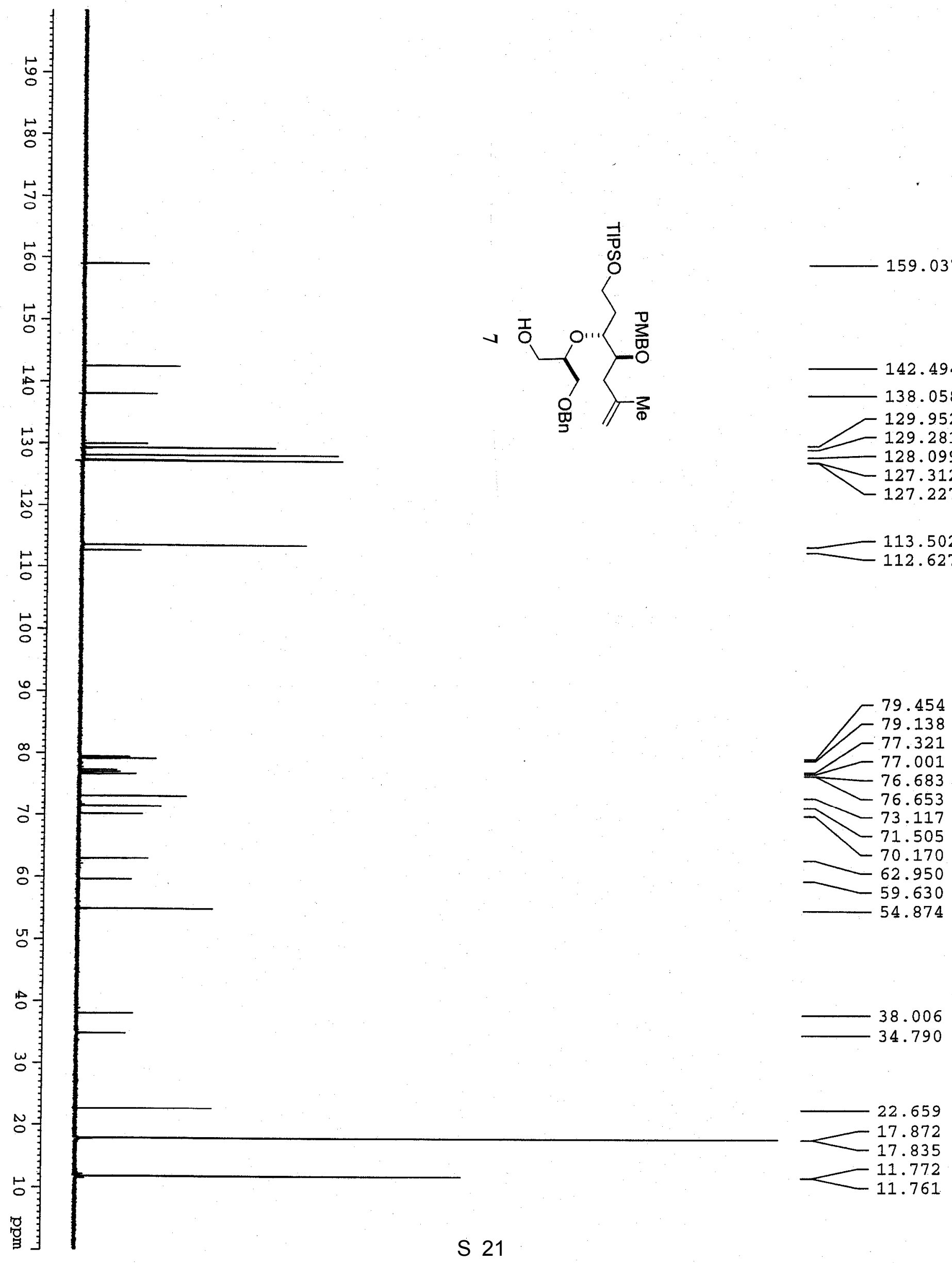


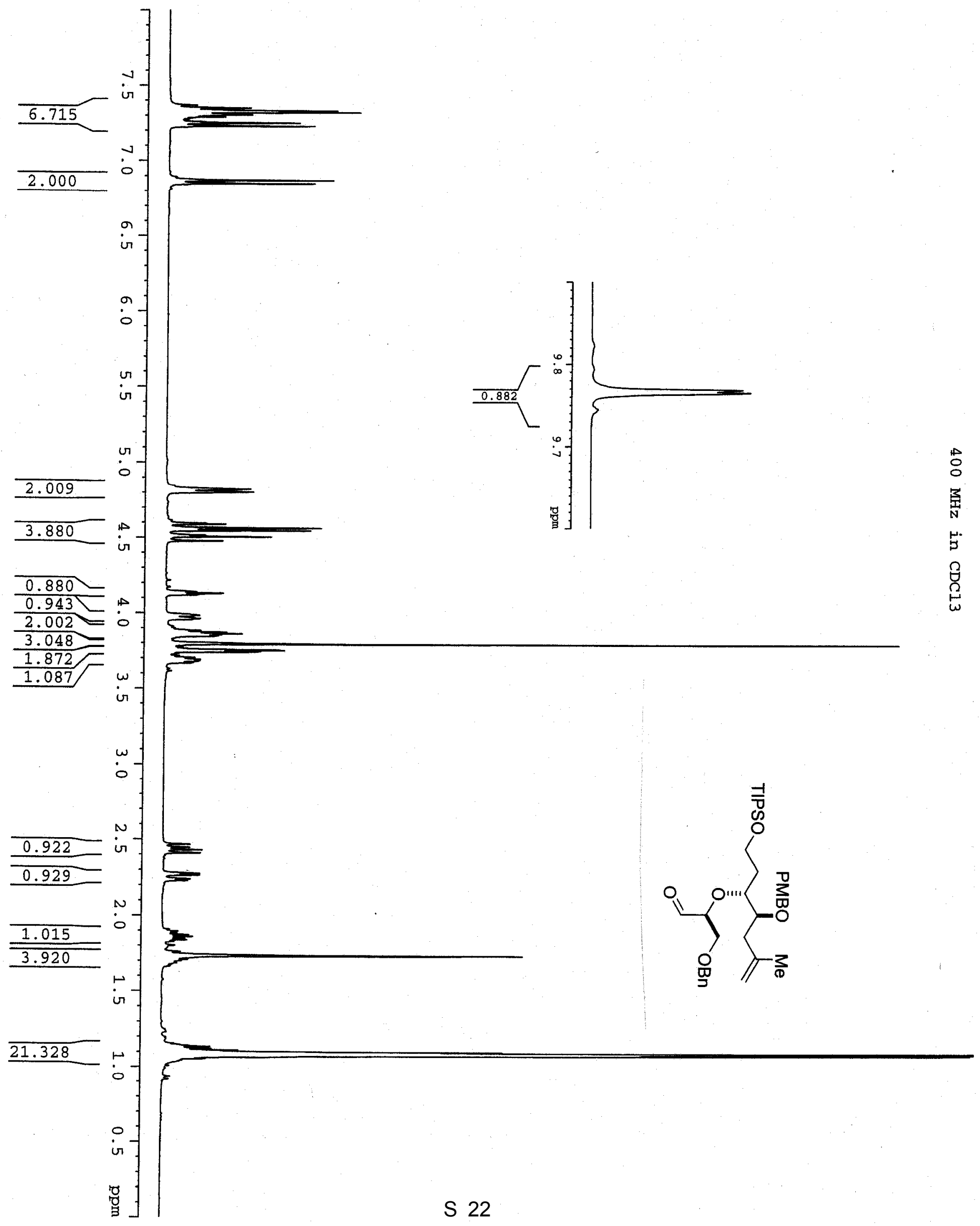



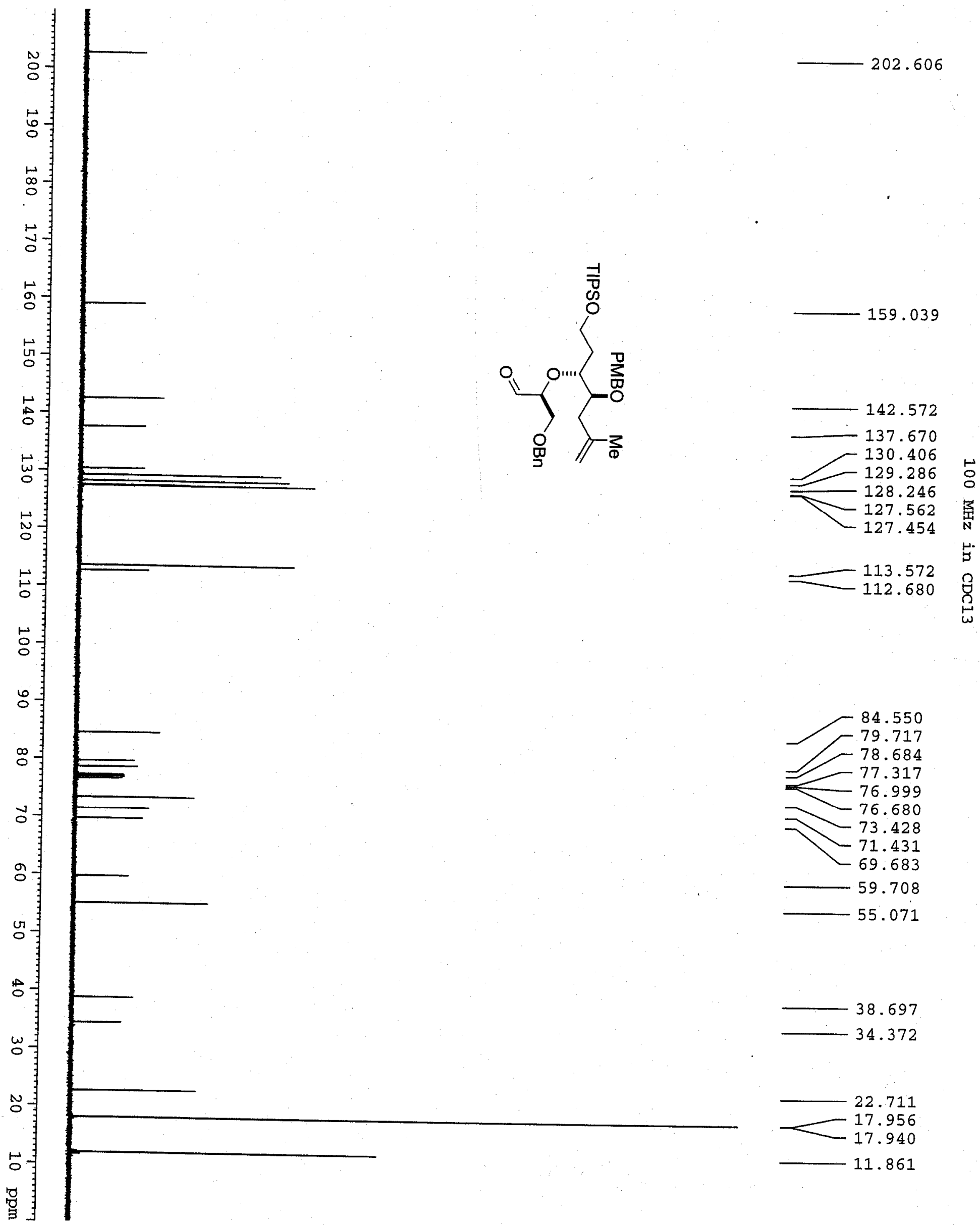


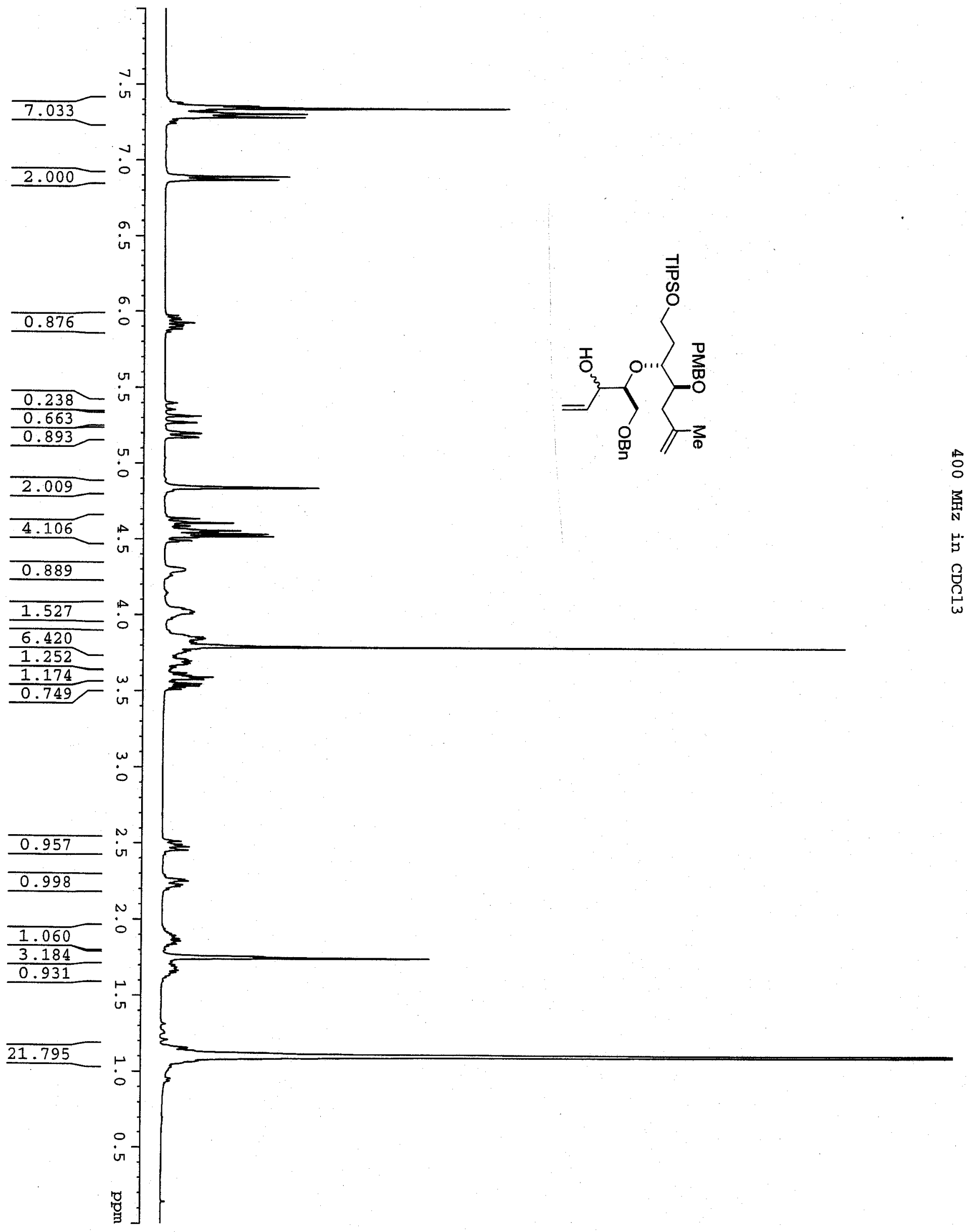



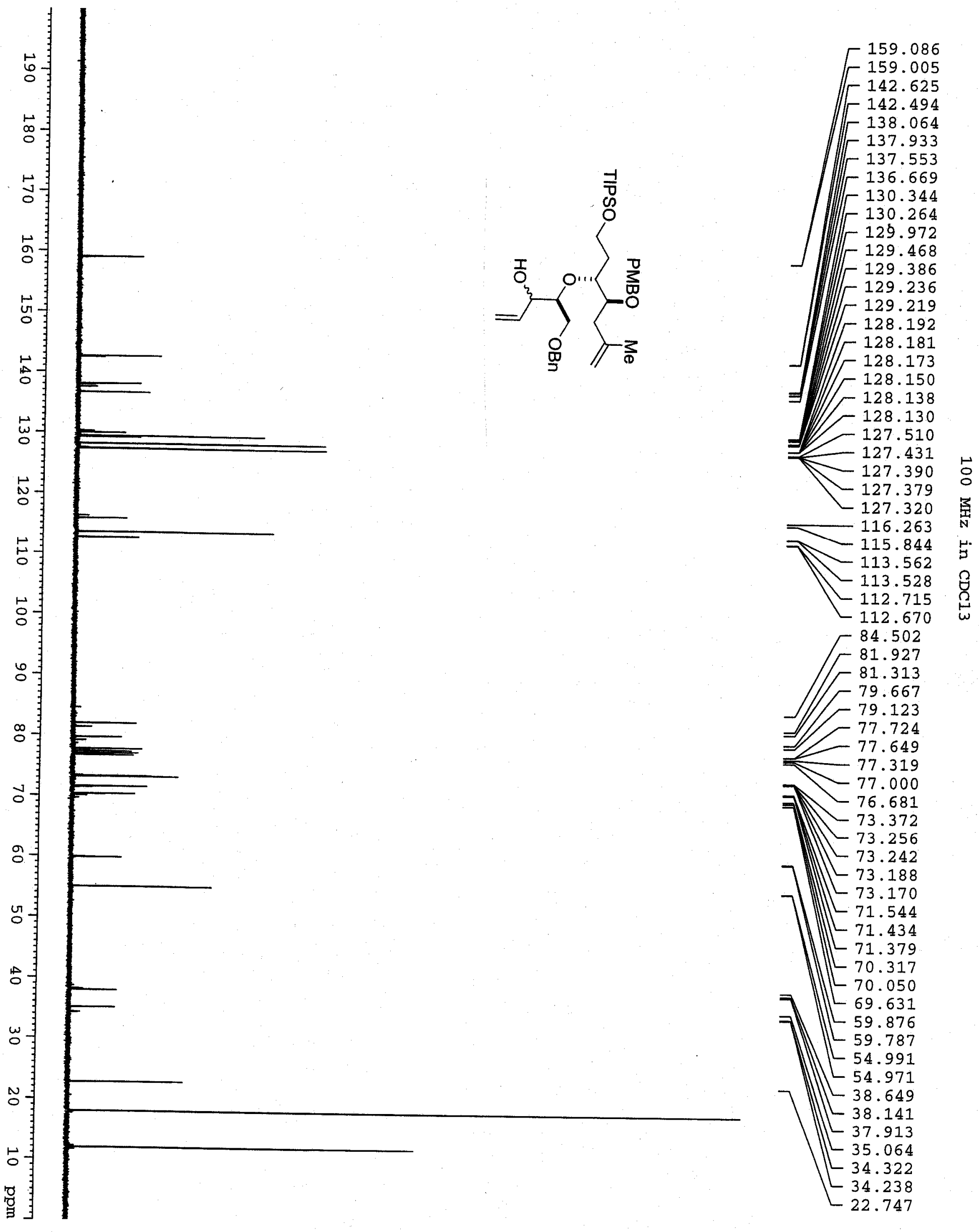


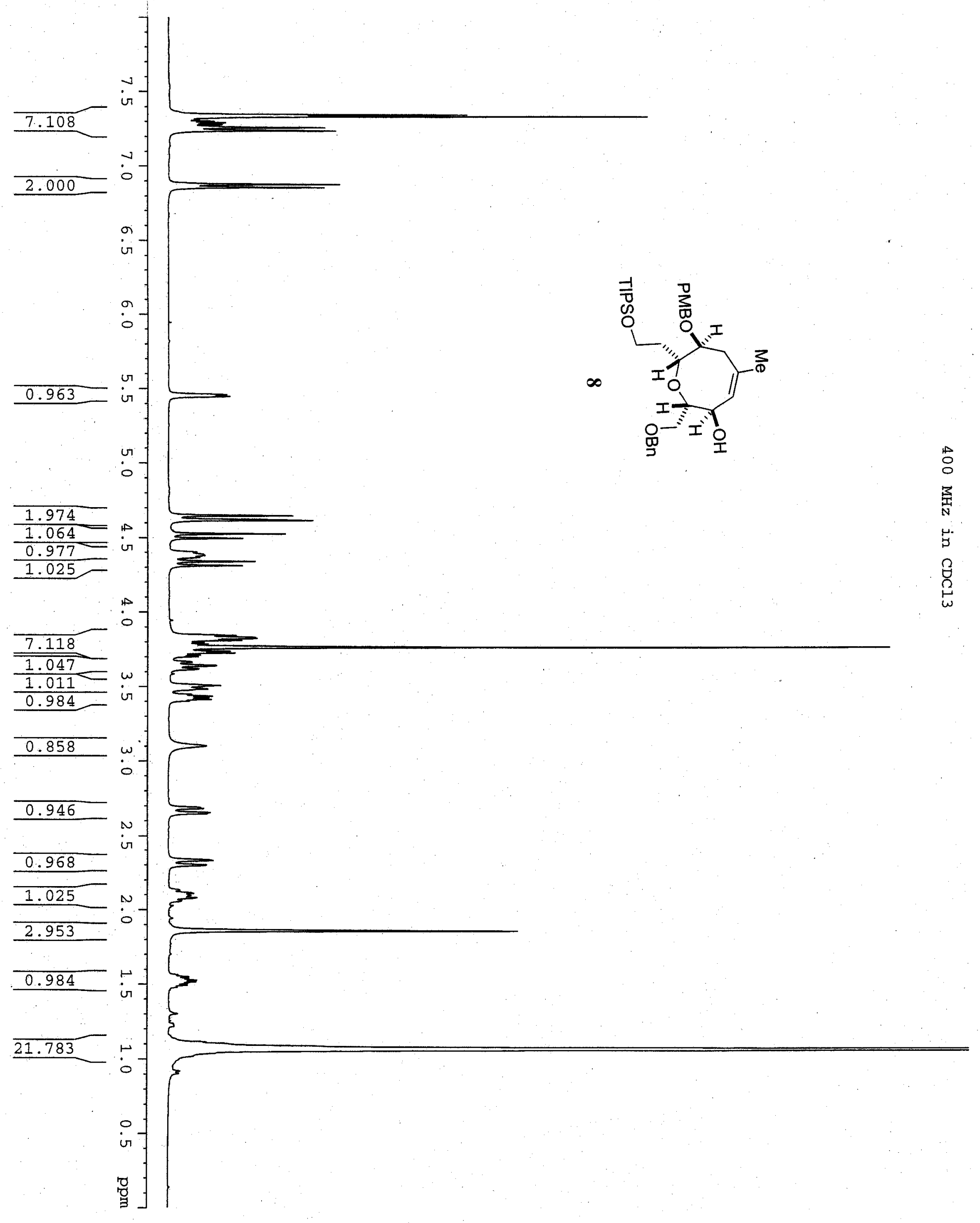



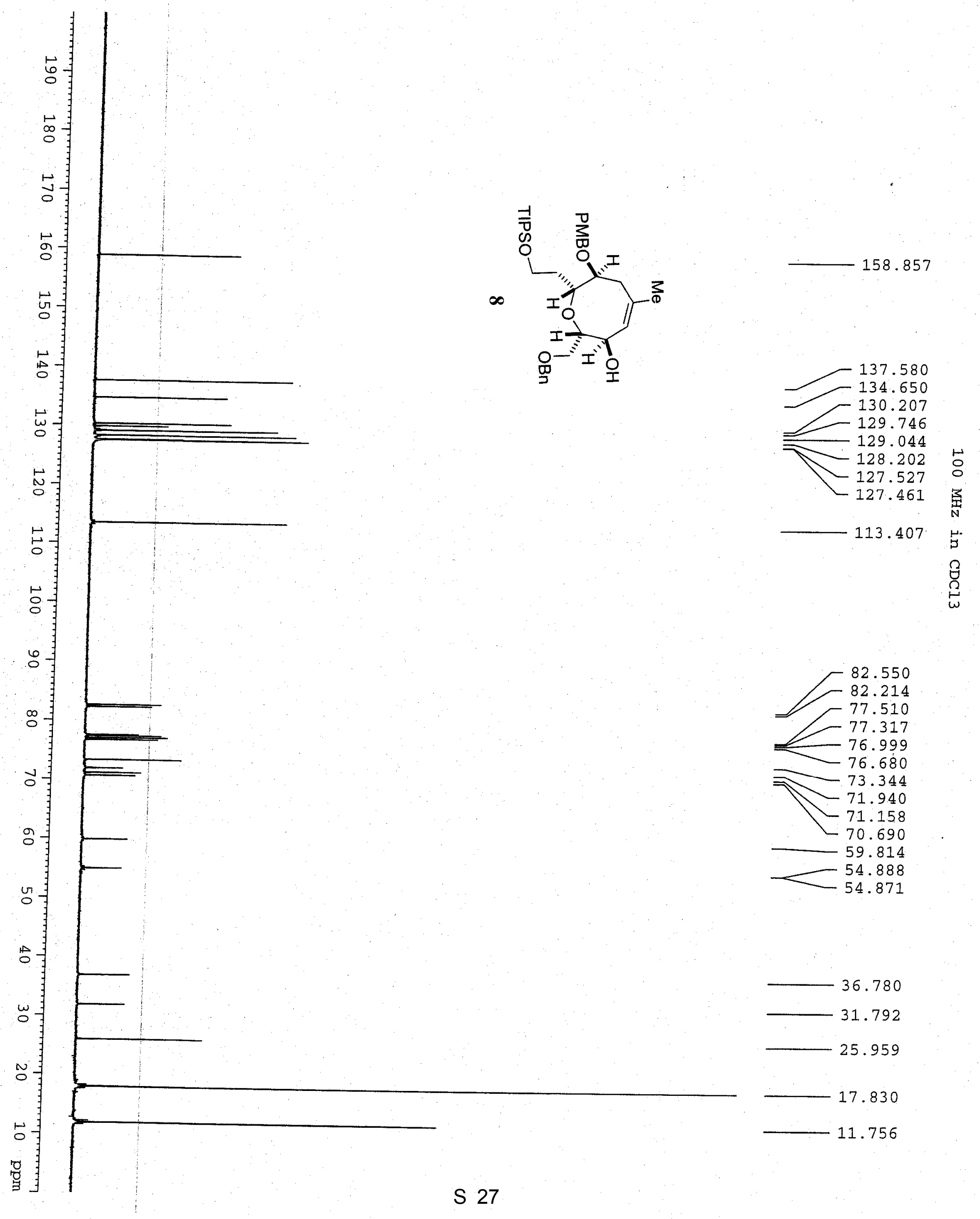


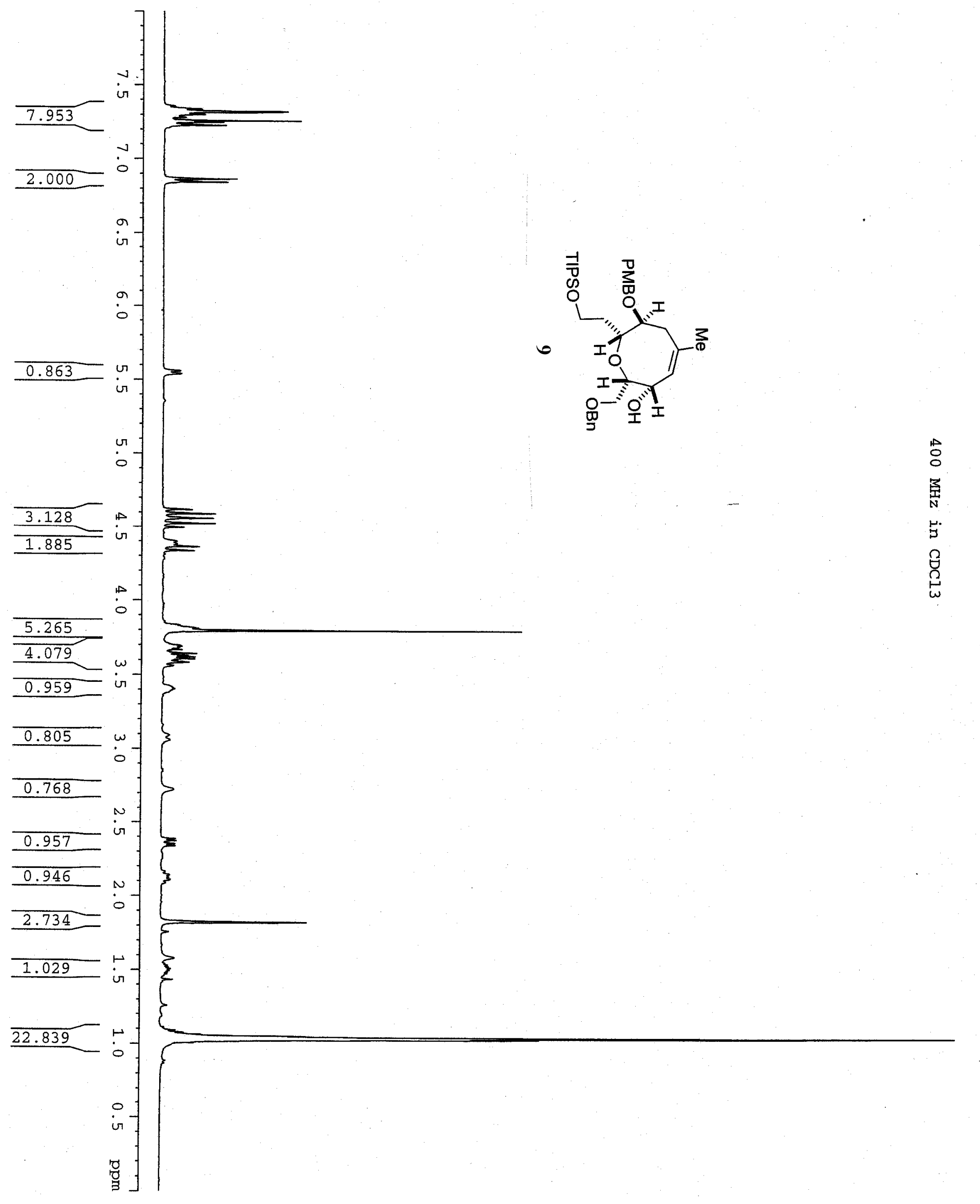




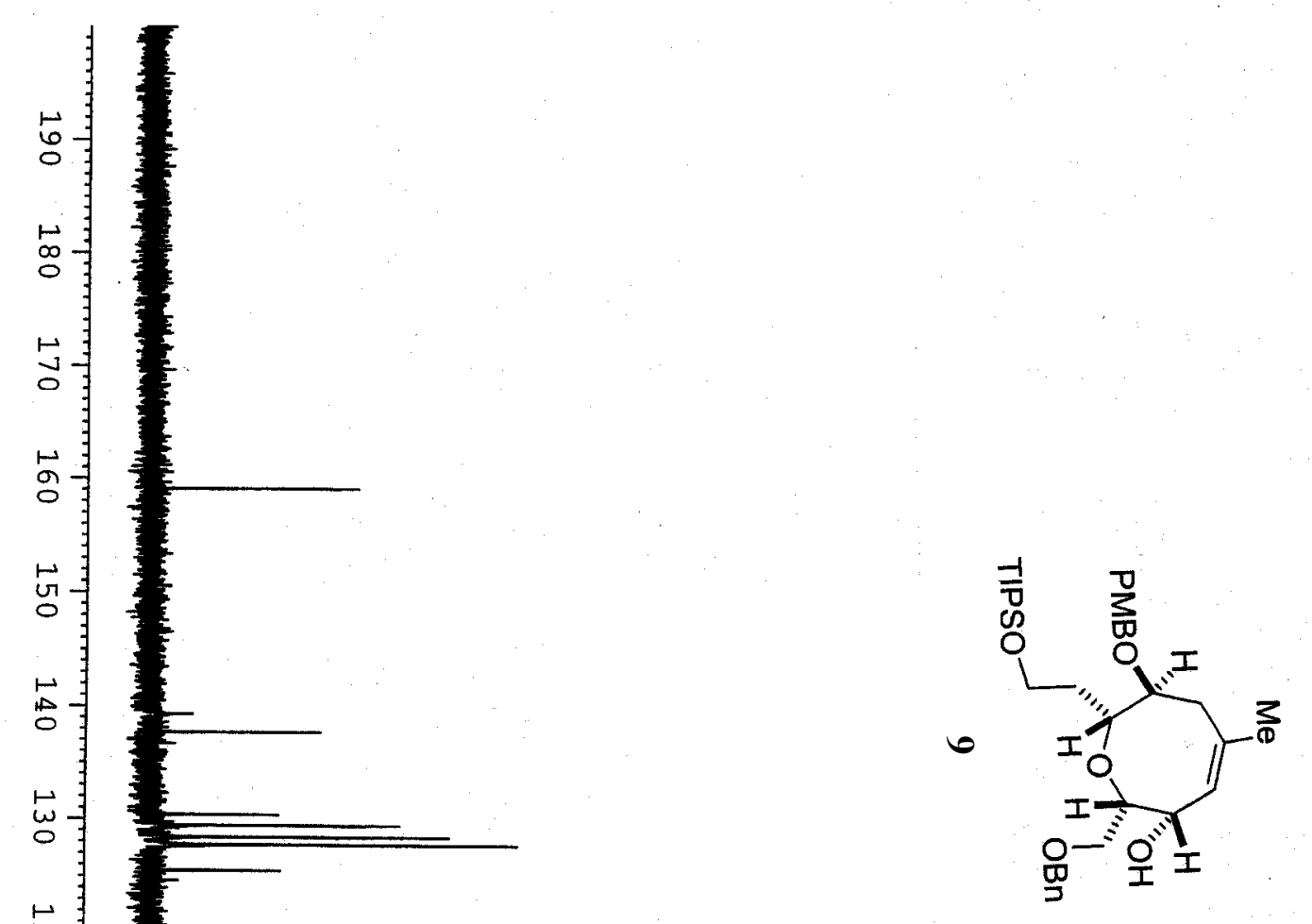

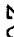

1

5

6

$\infty$

ปै

응

.

I

品

w.

N

5

ס

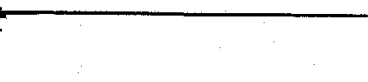

113.678
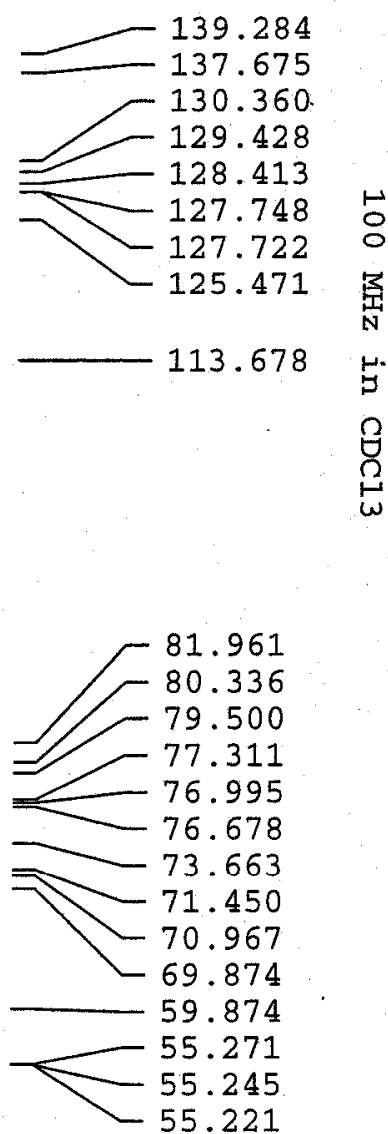

$-37.143$

33.910

26.778

18.316

18.038

17.758

11.968 


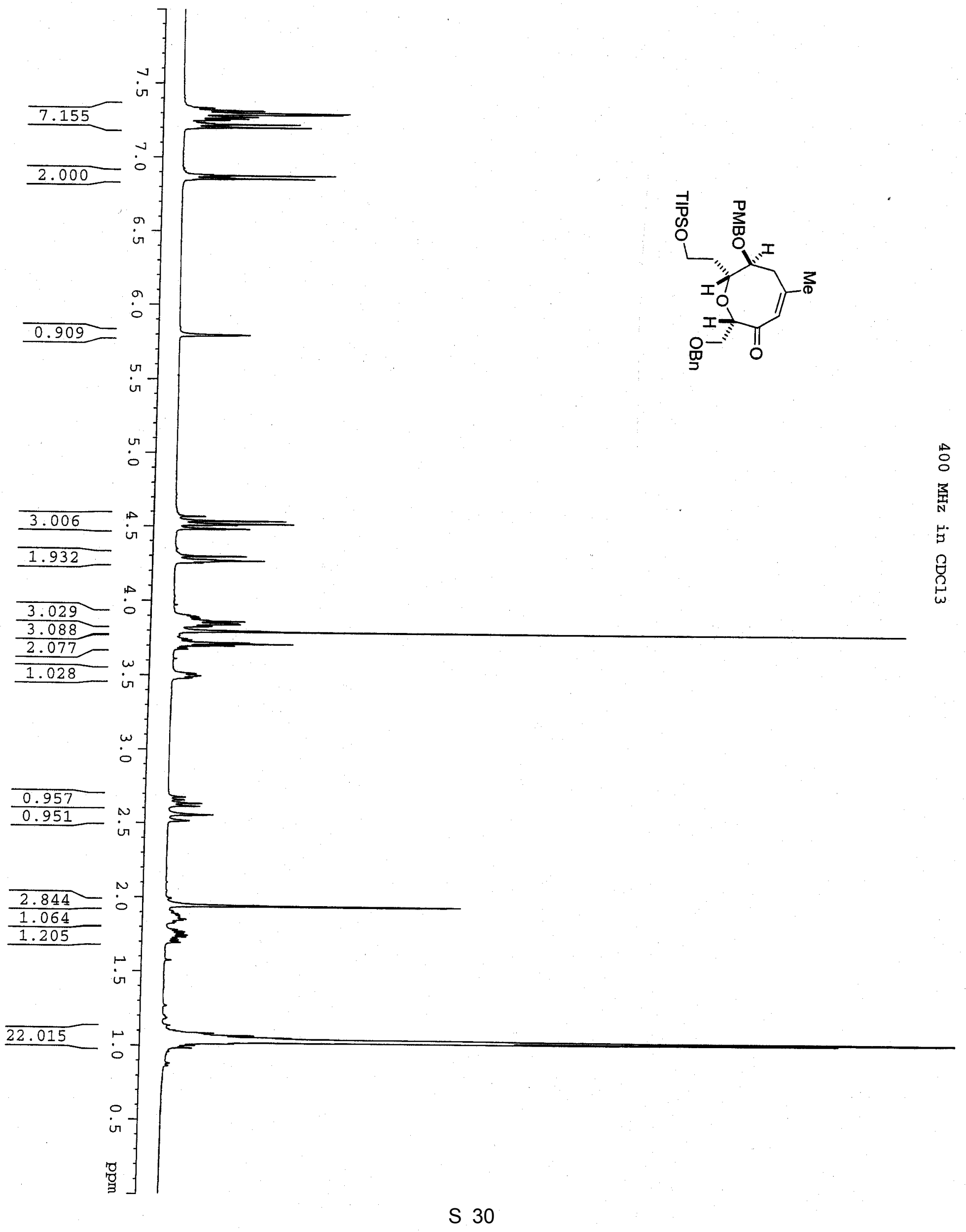



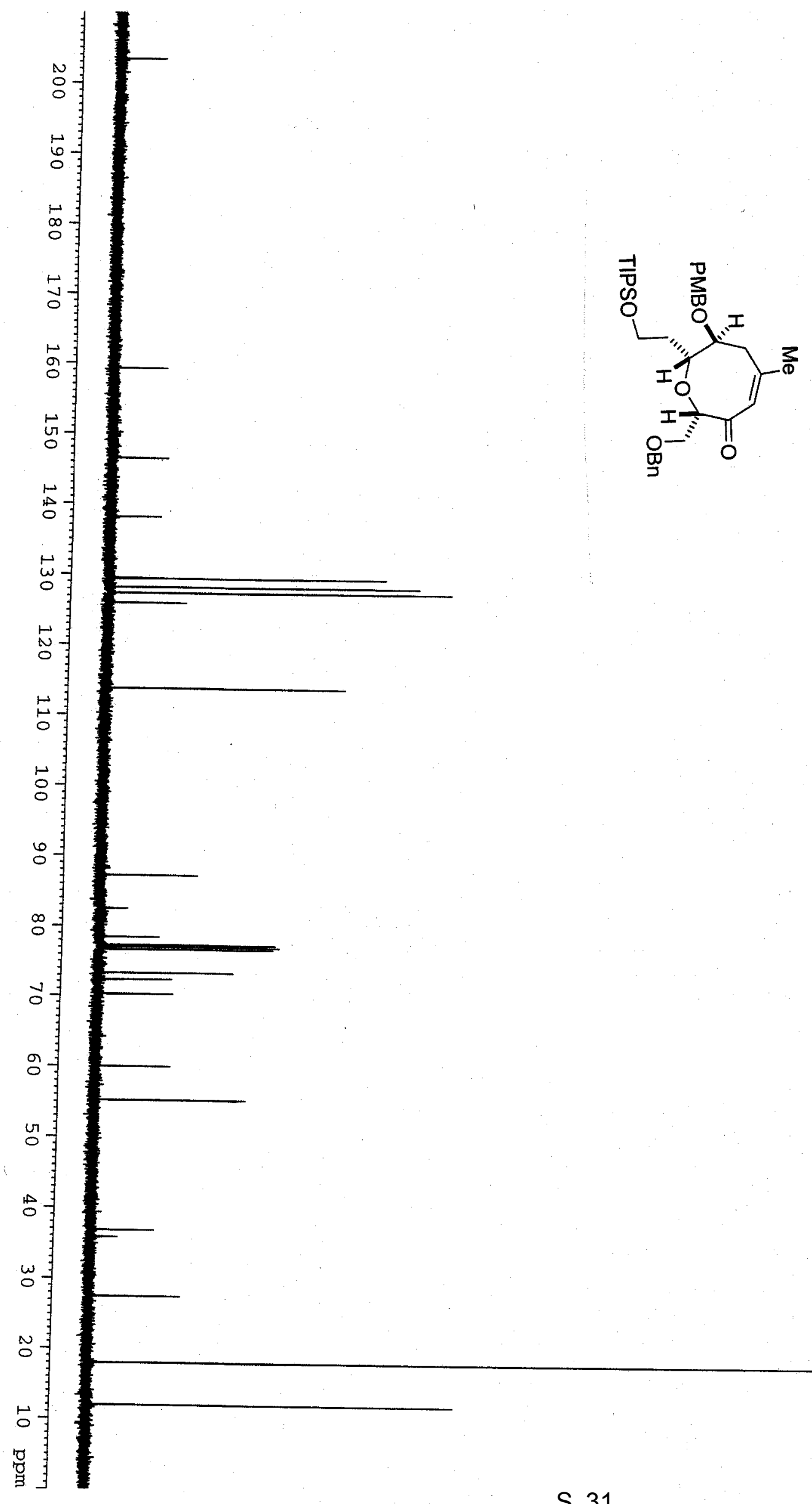

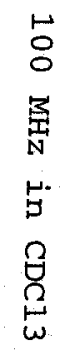
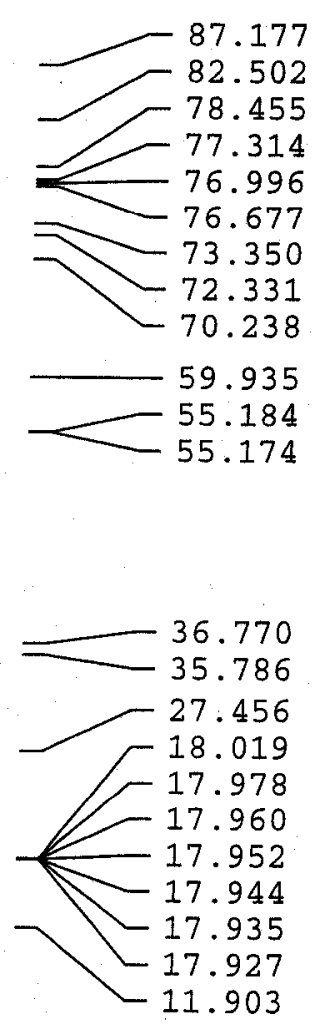


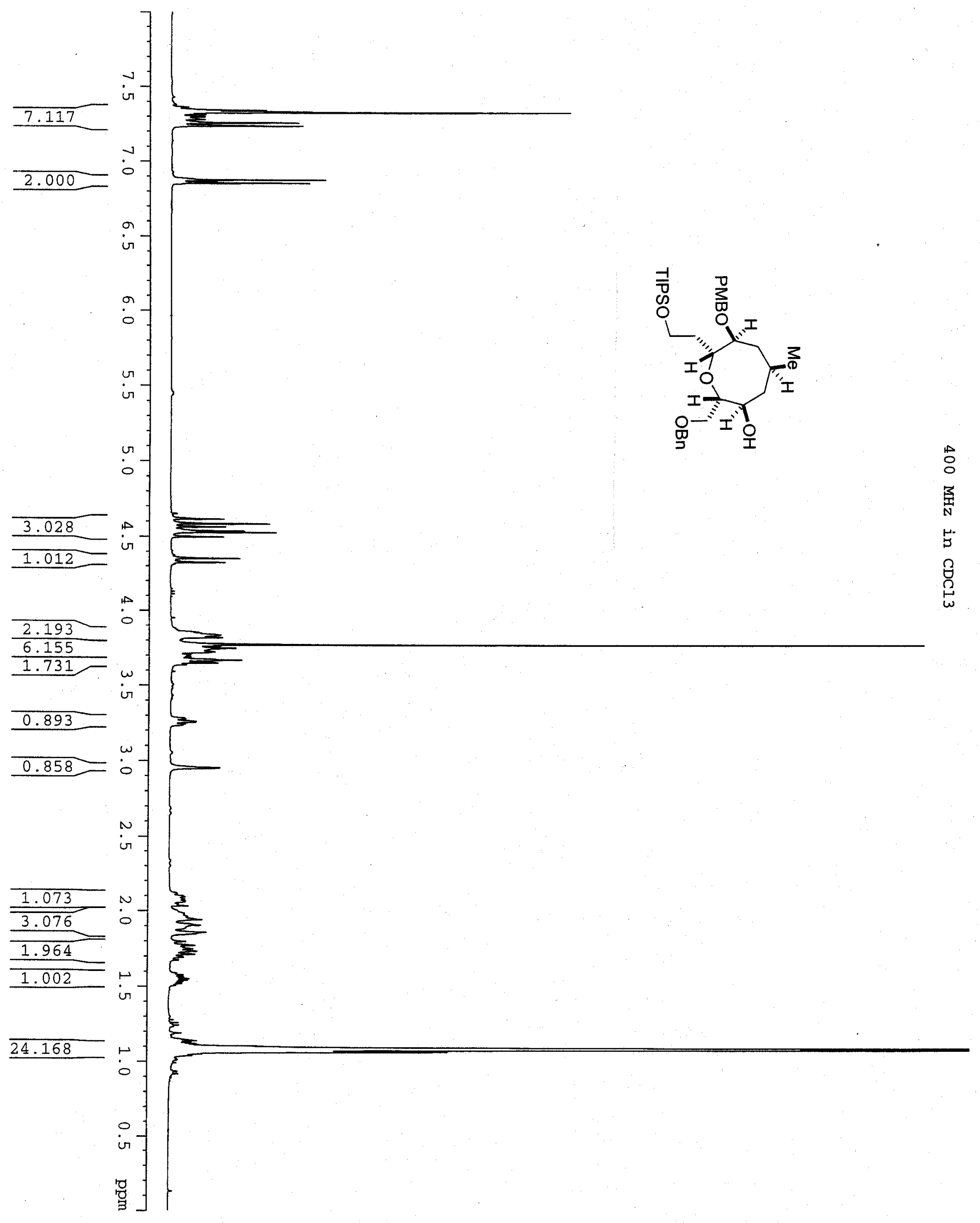



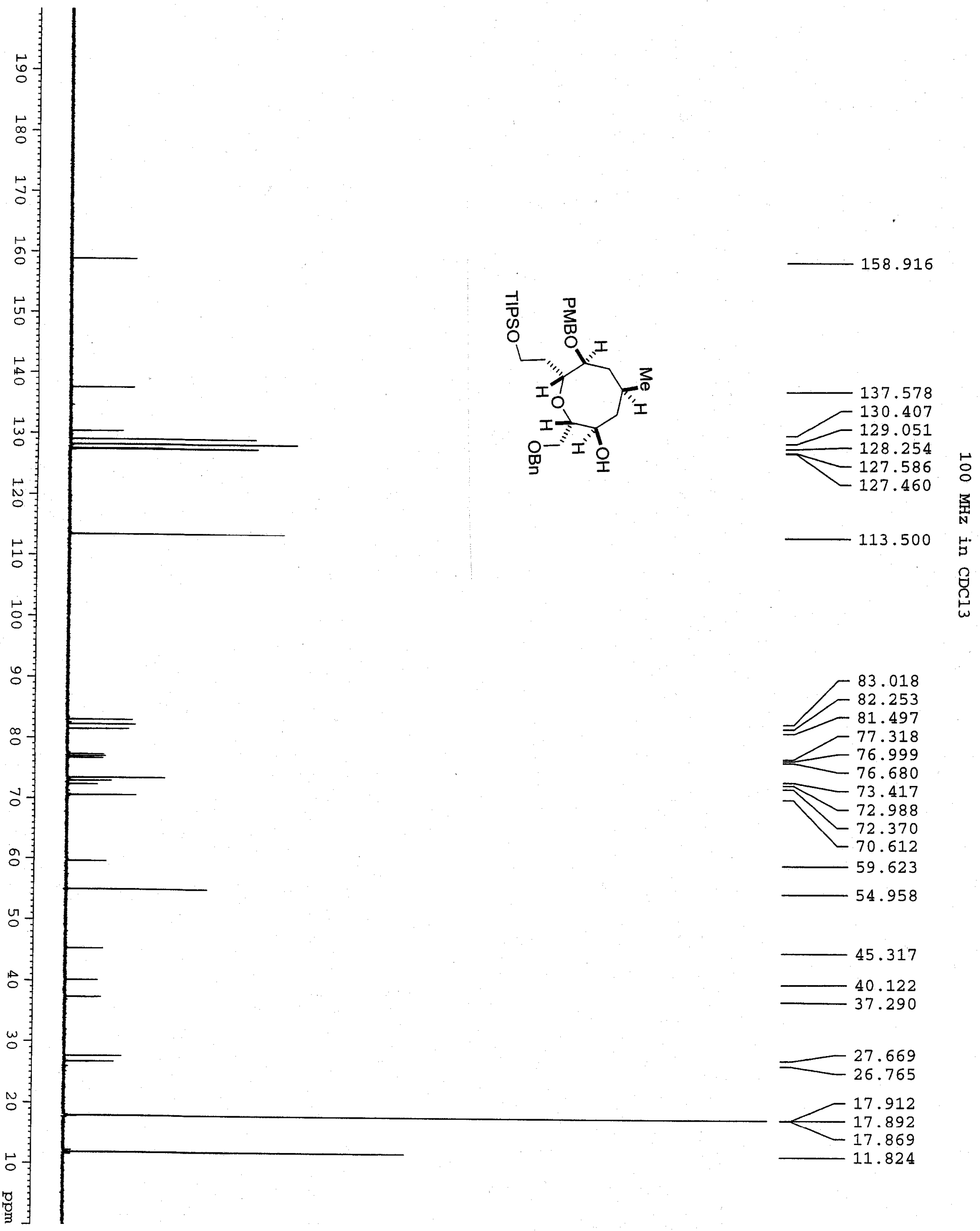

45.317

40.122 37.290

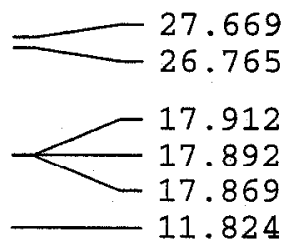




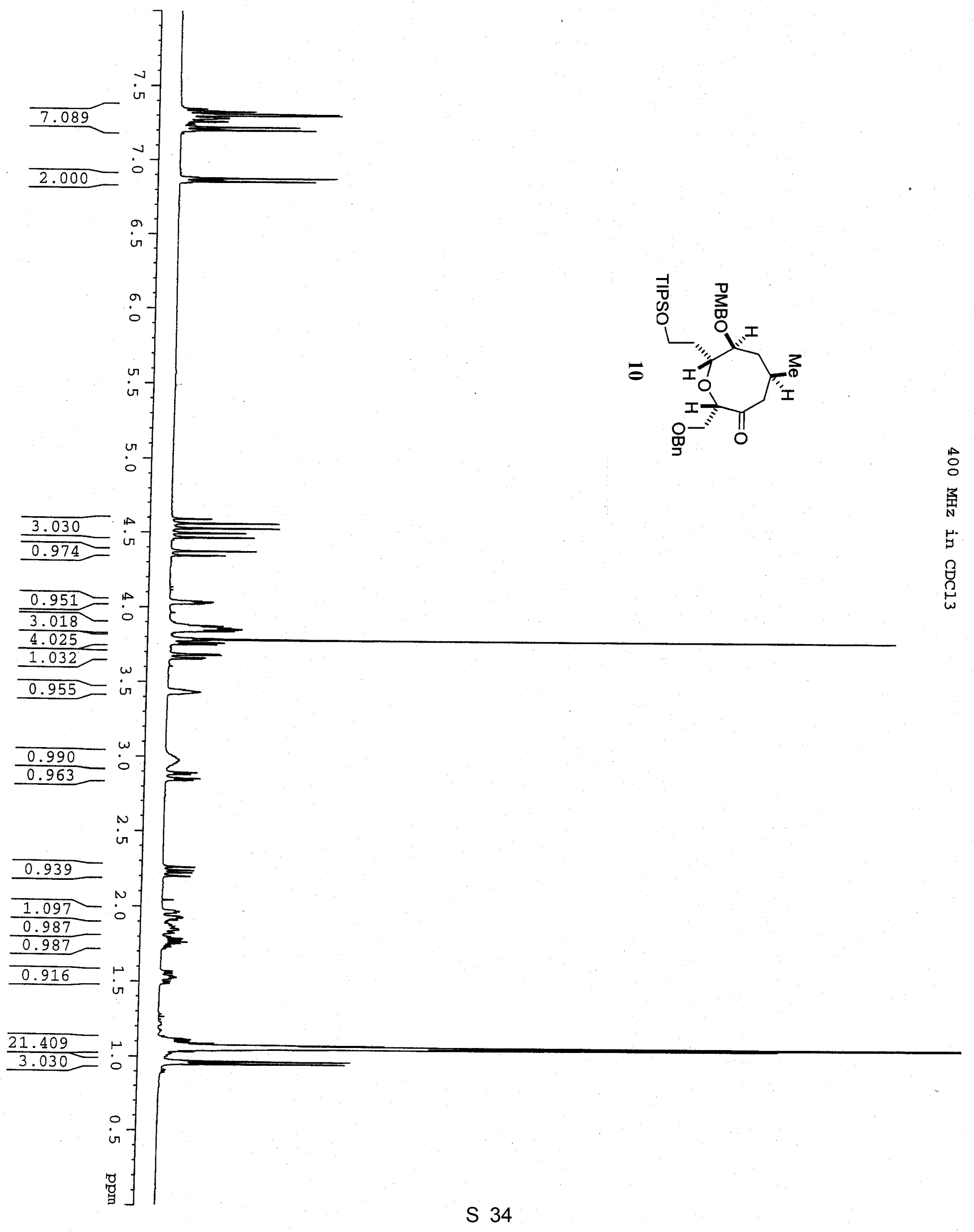



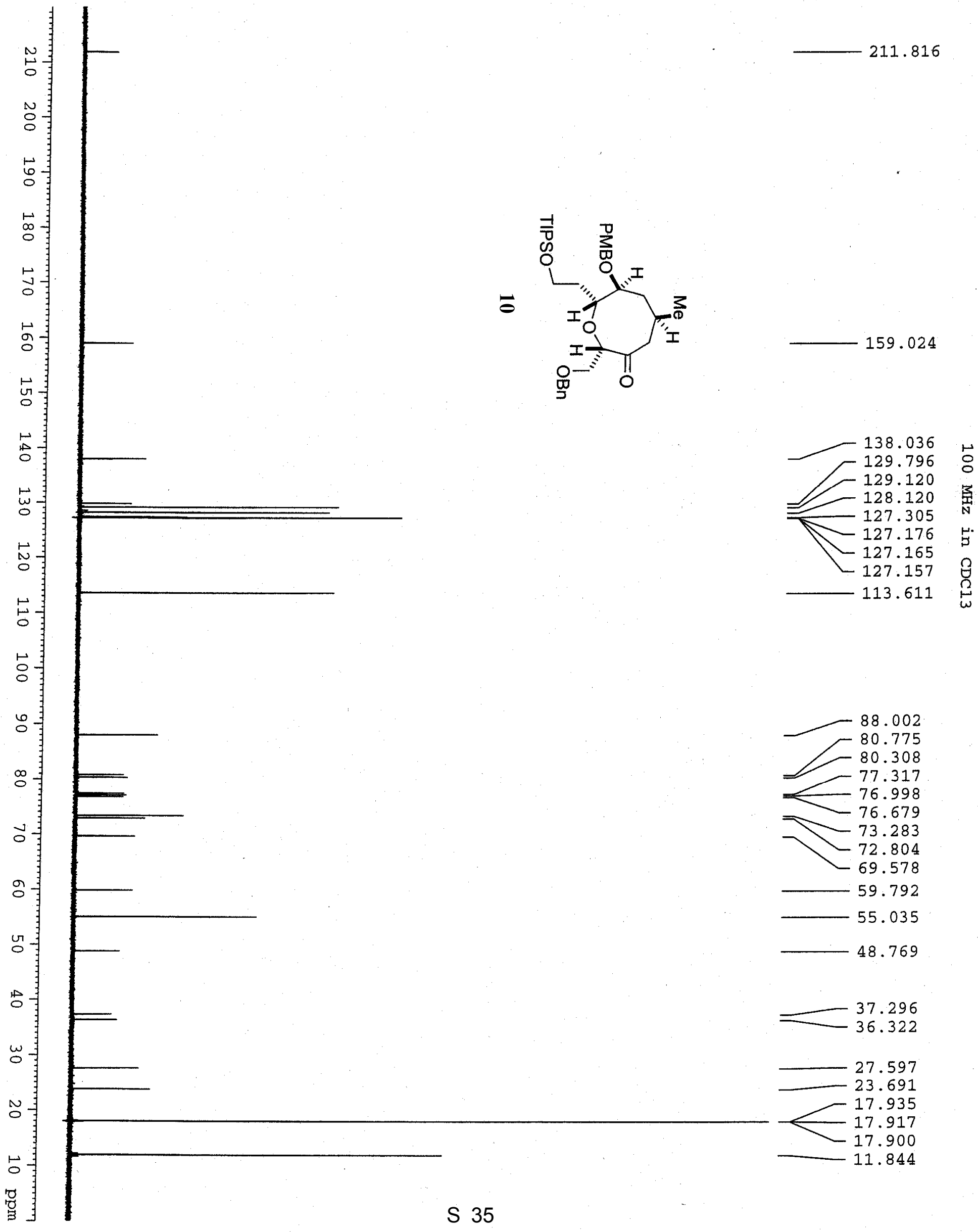


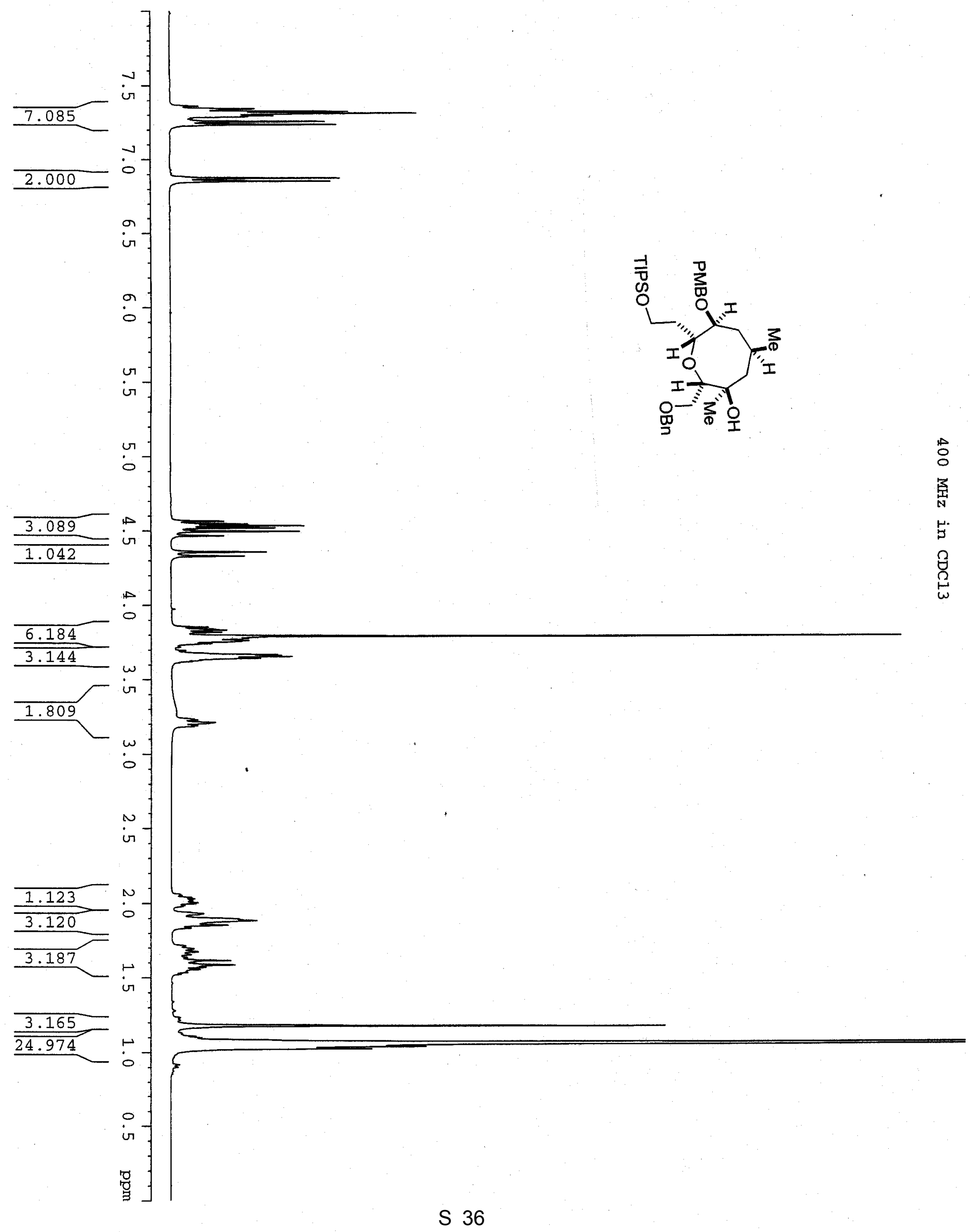



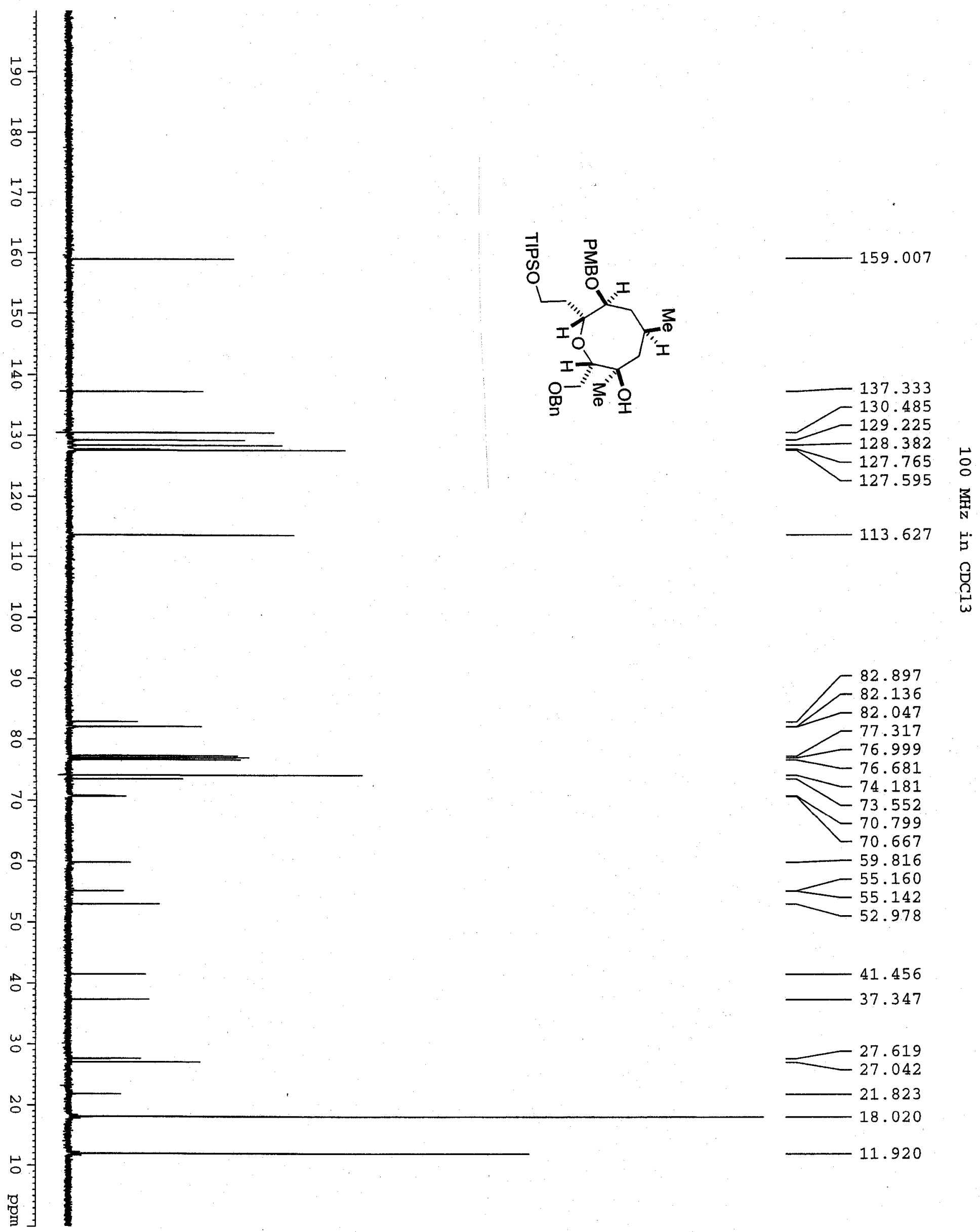


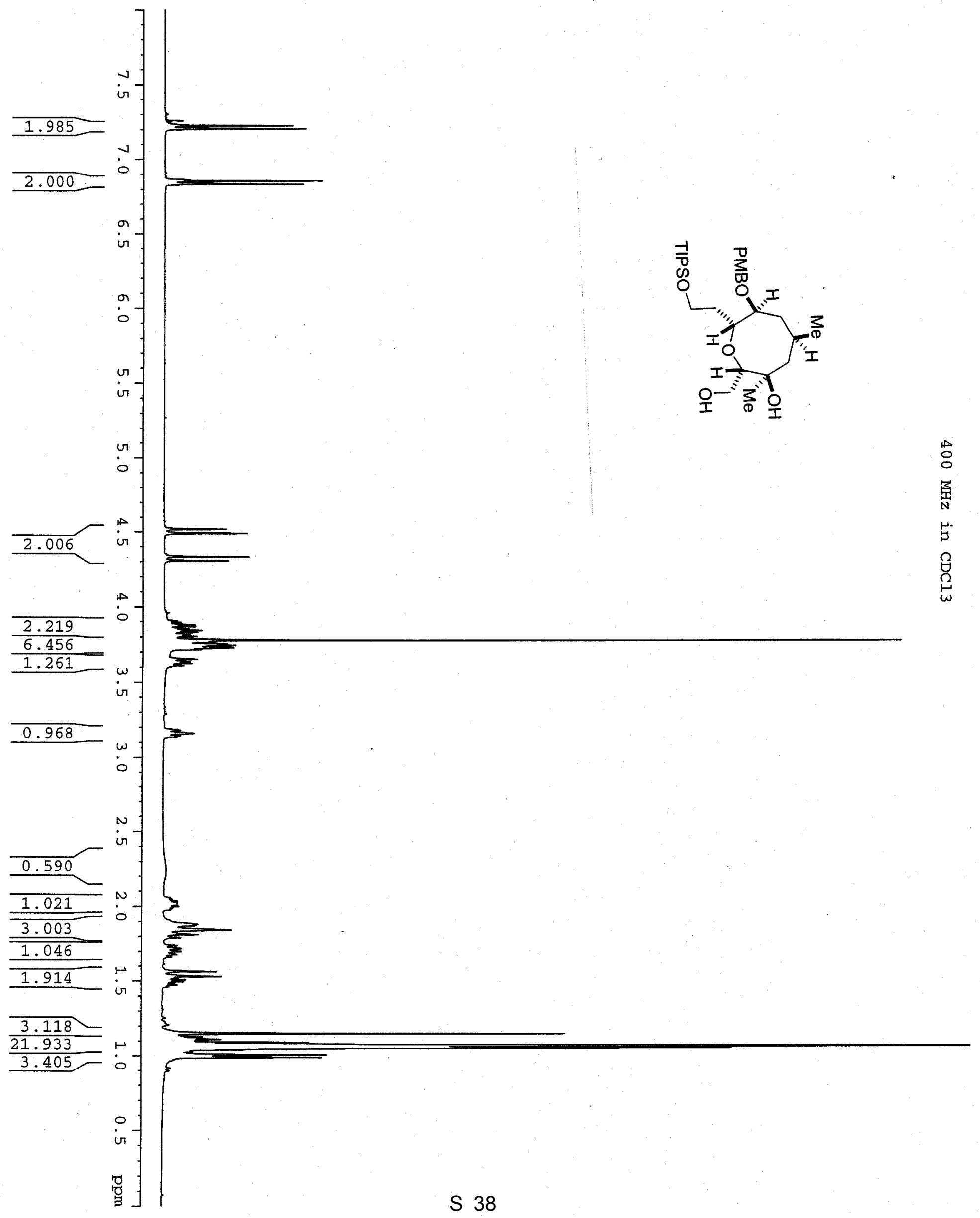



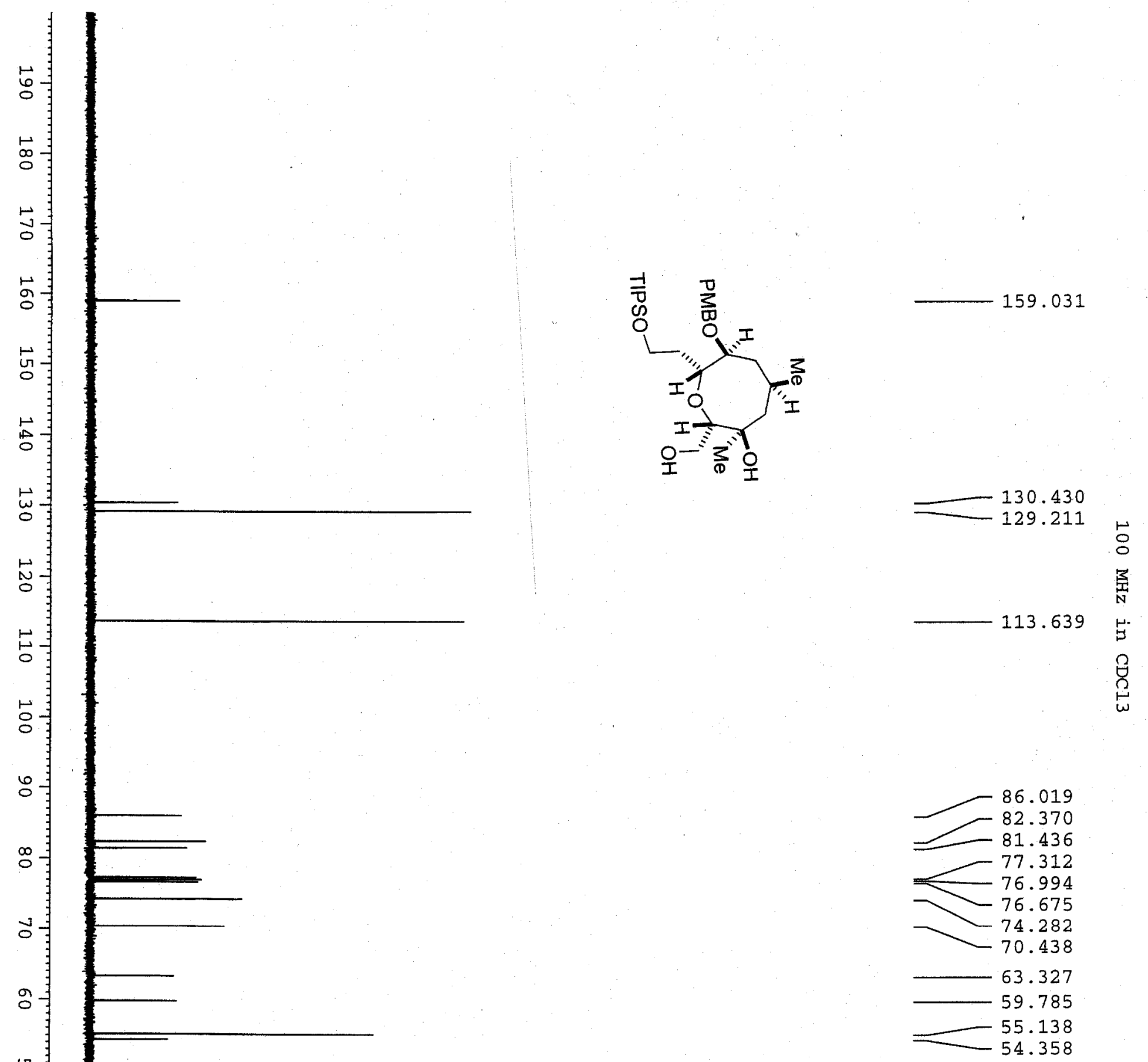

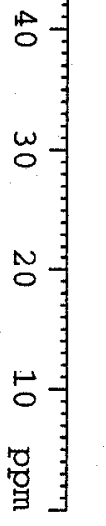

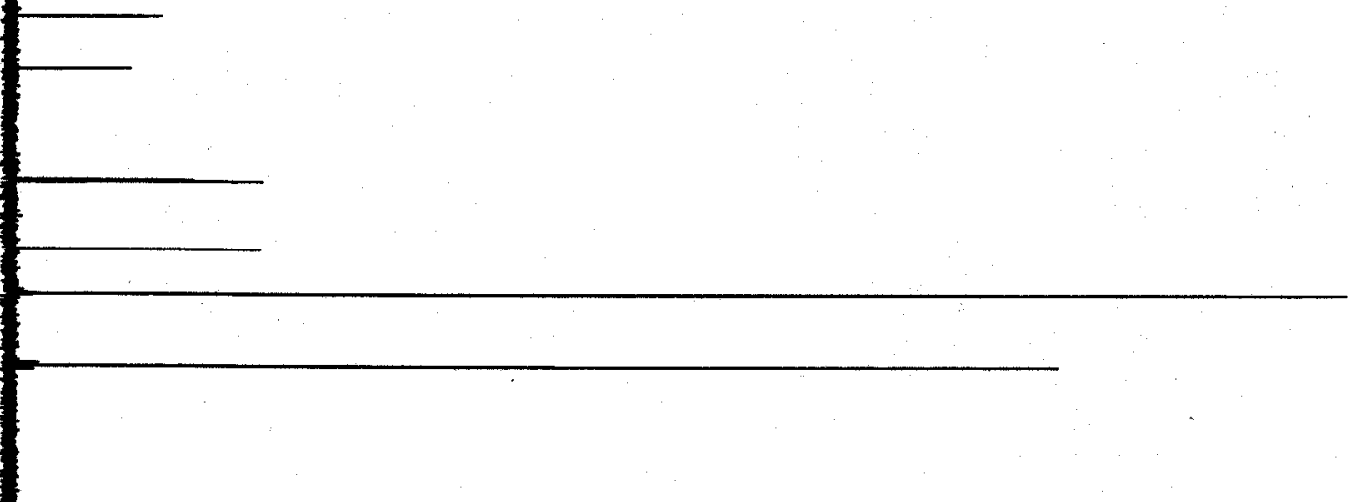




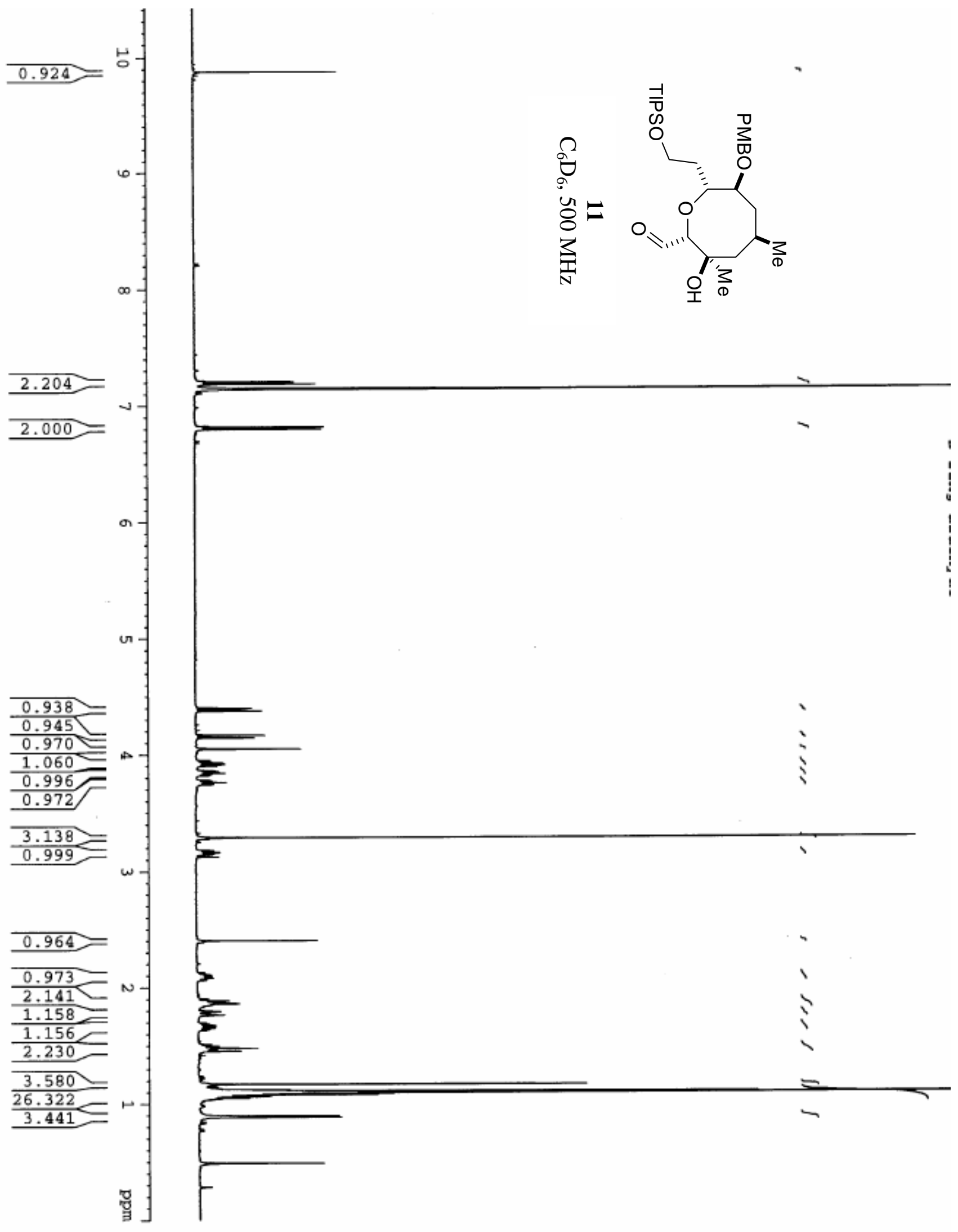




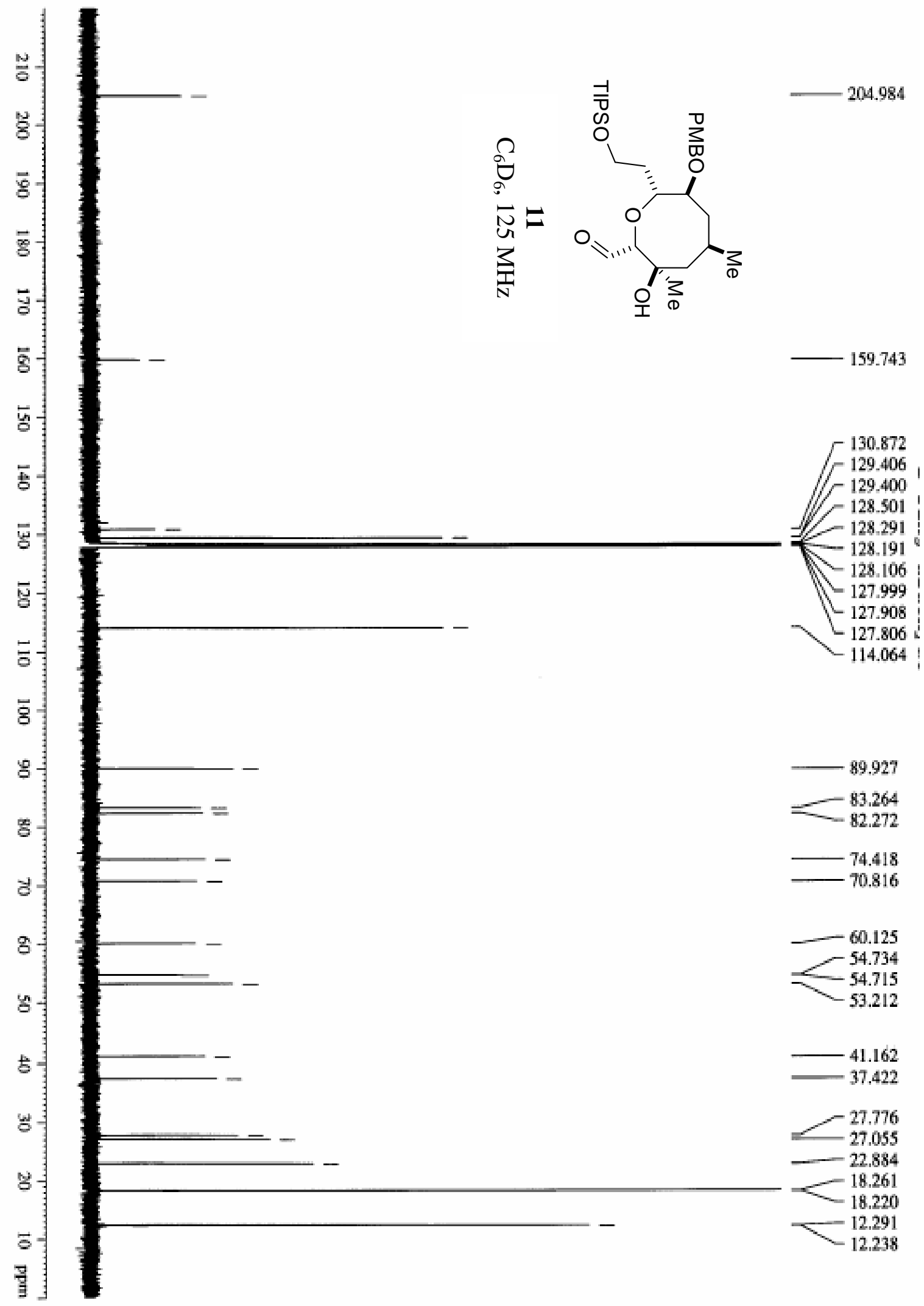




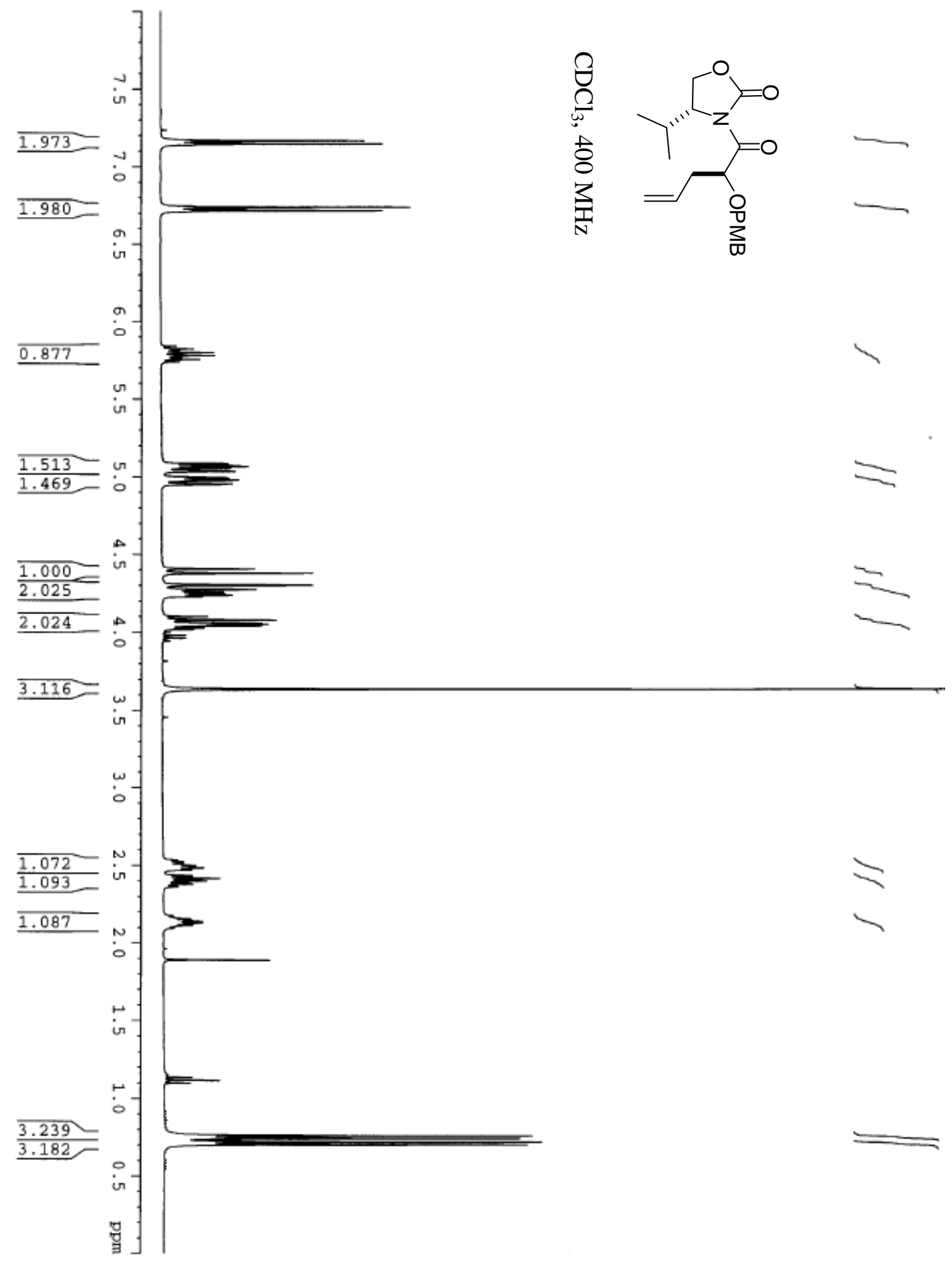




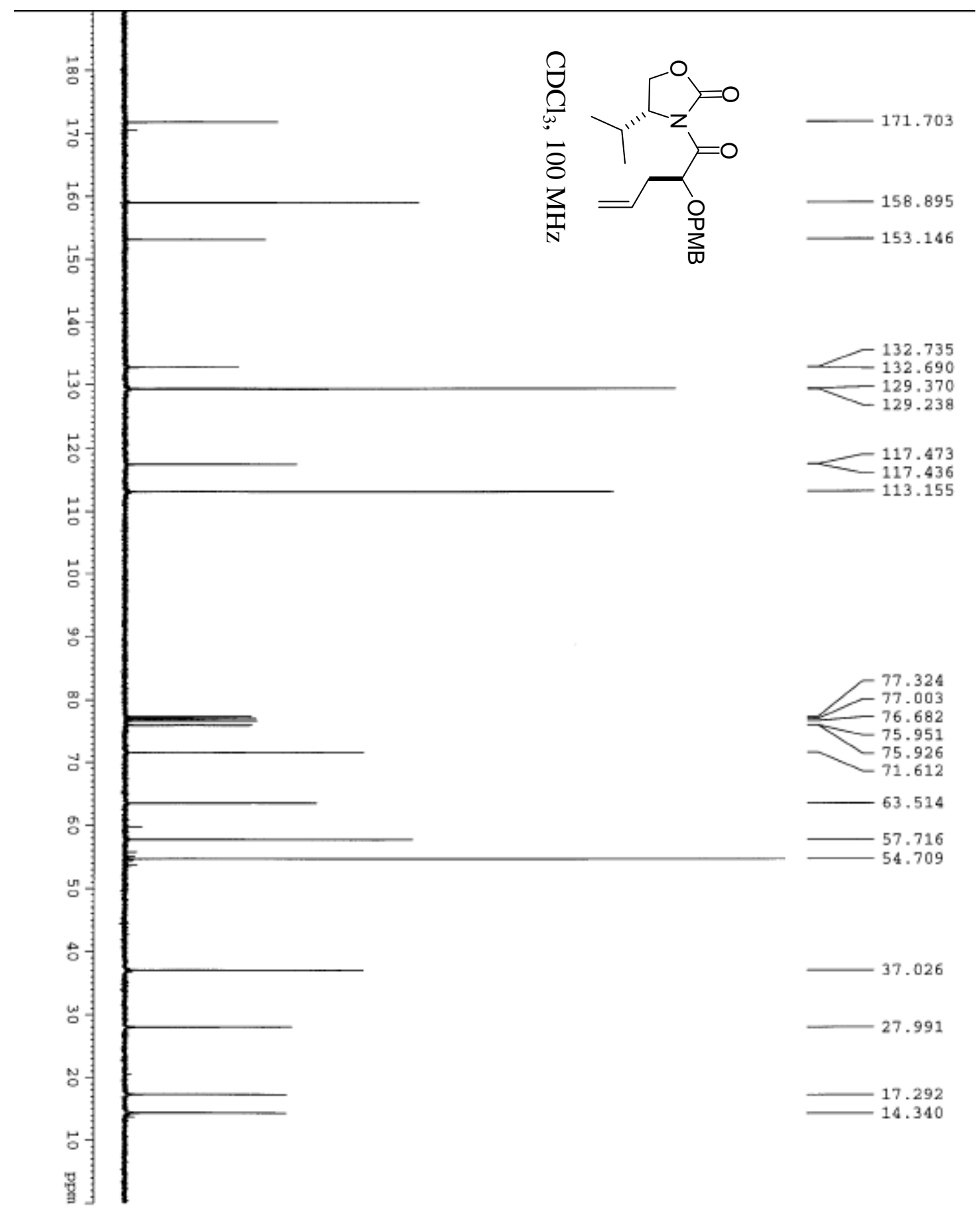




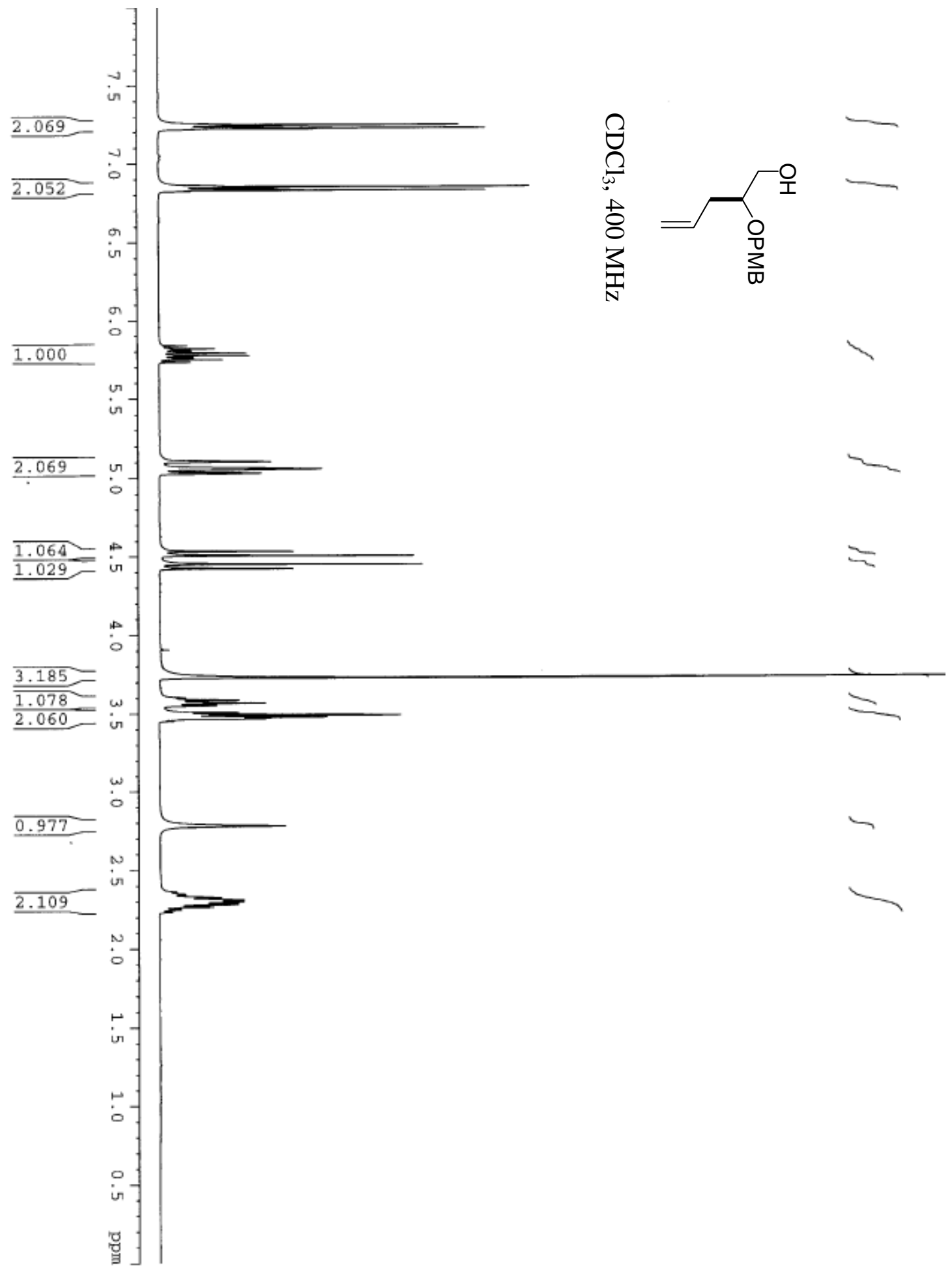



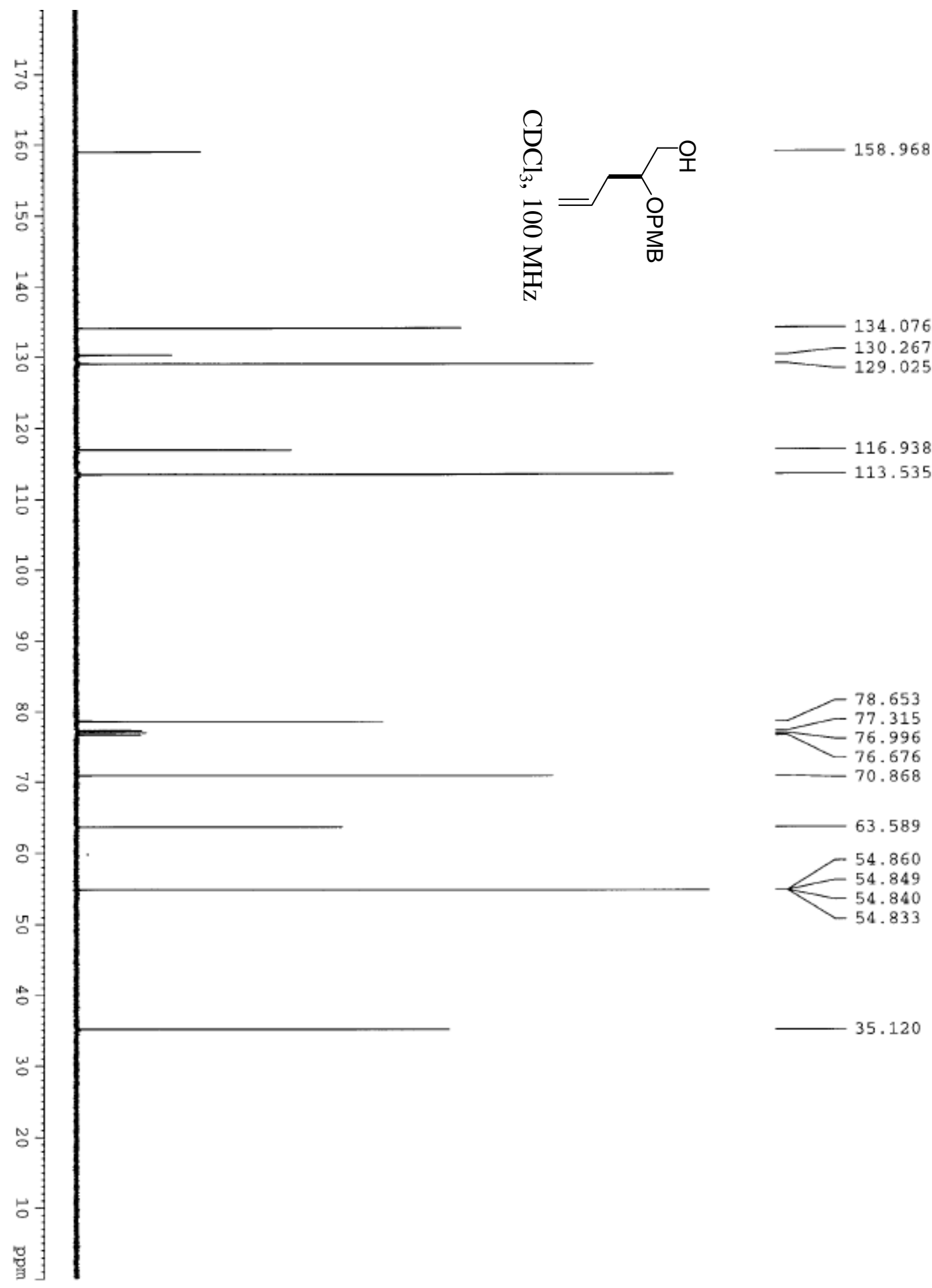

116.938 113.535

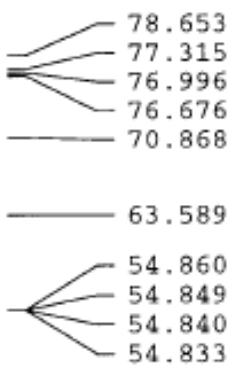

35.120 


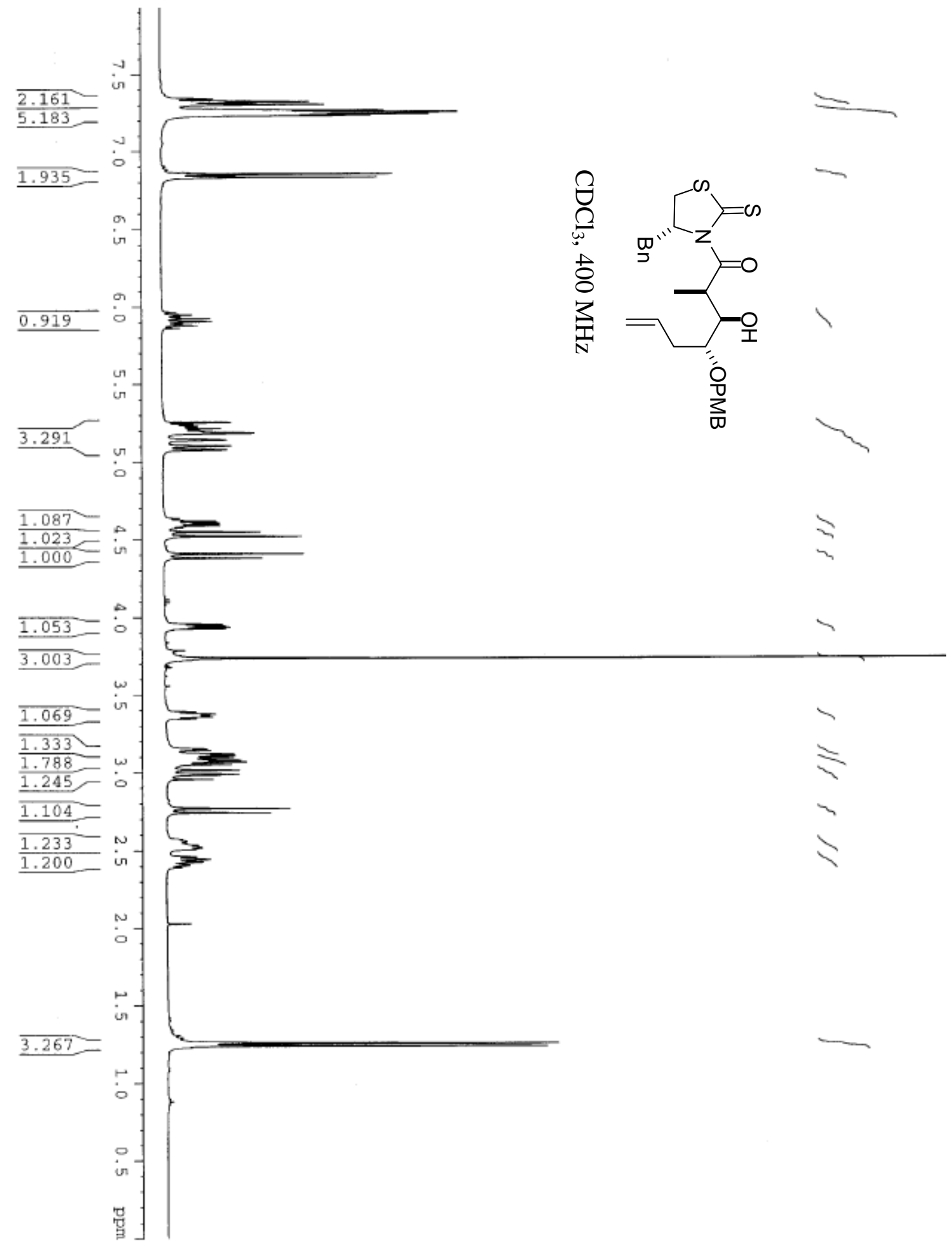




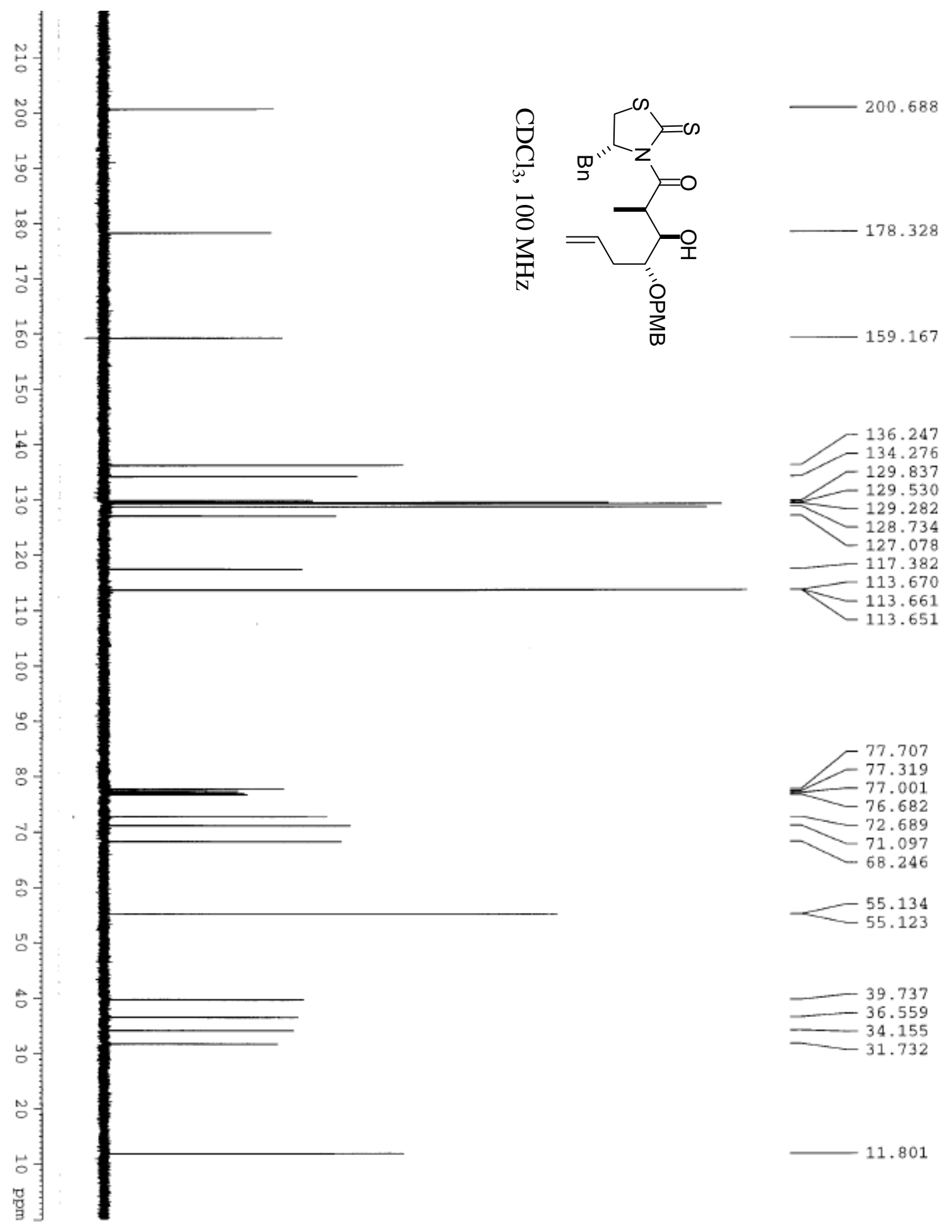




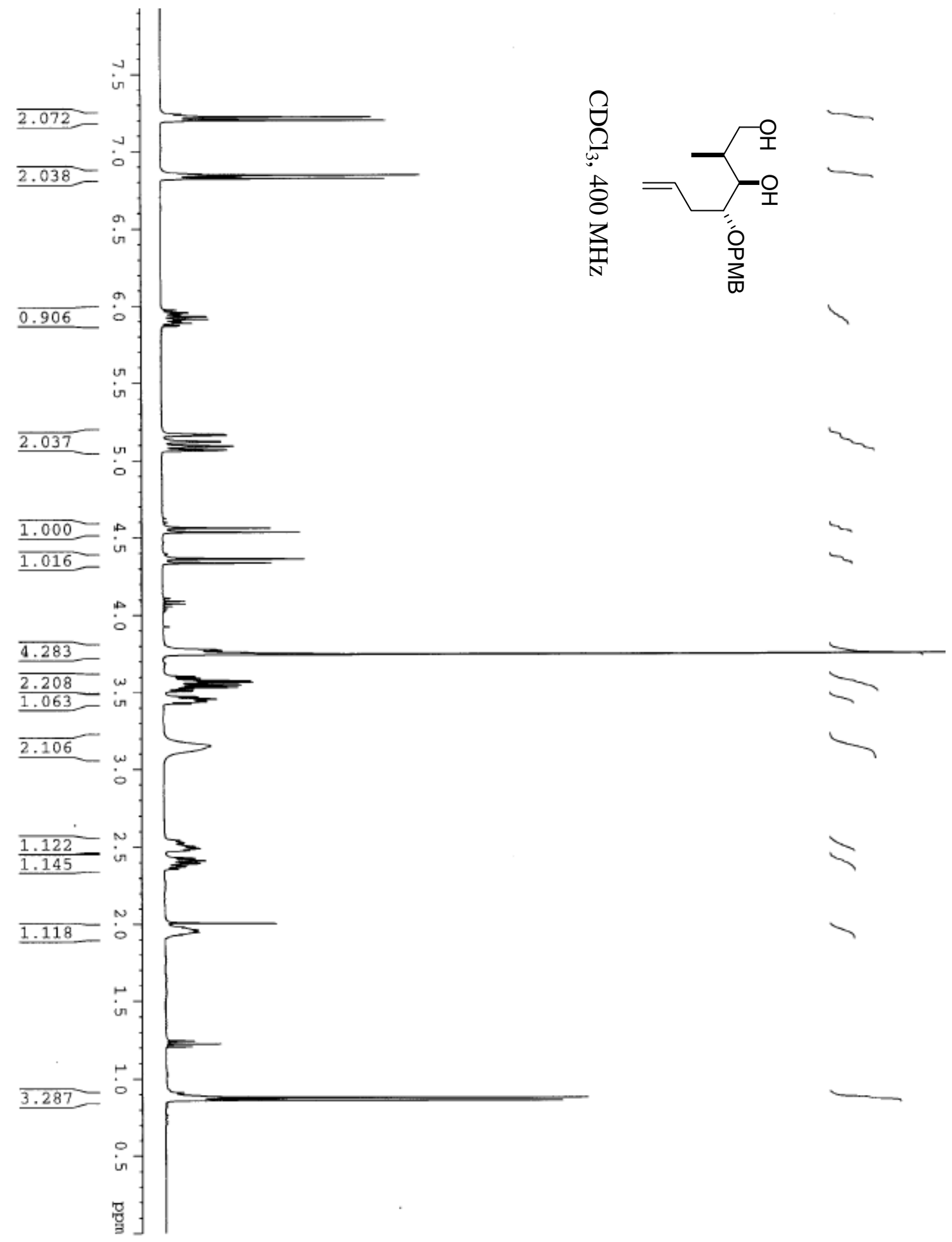



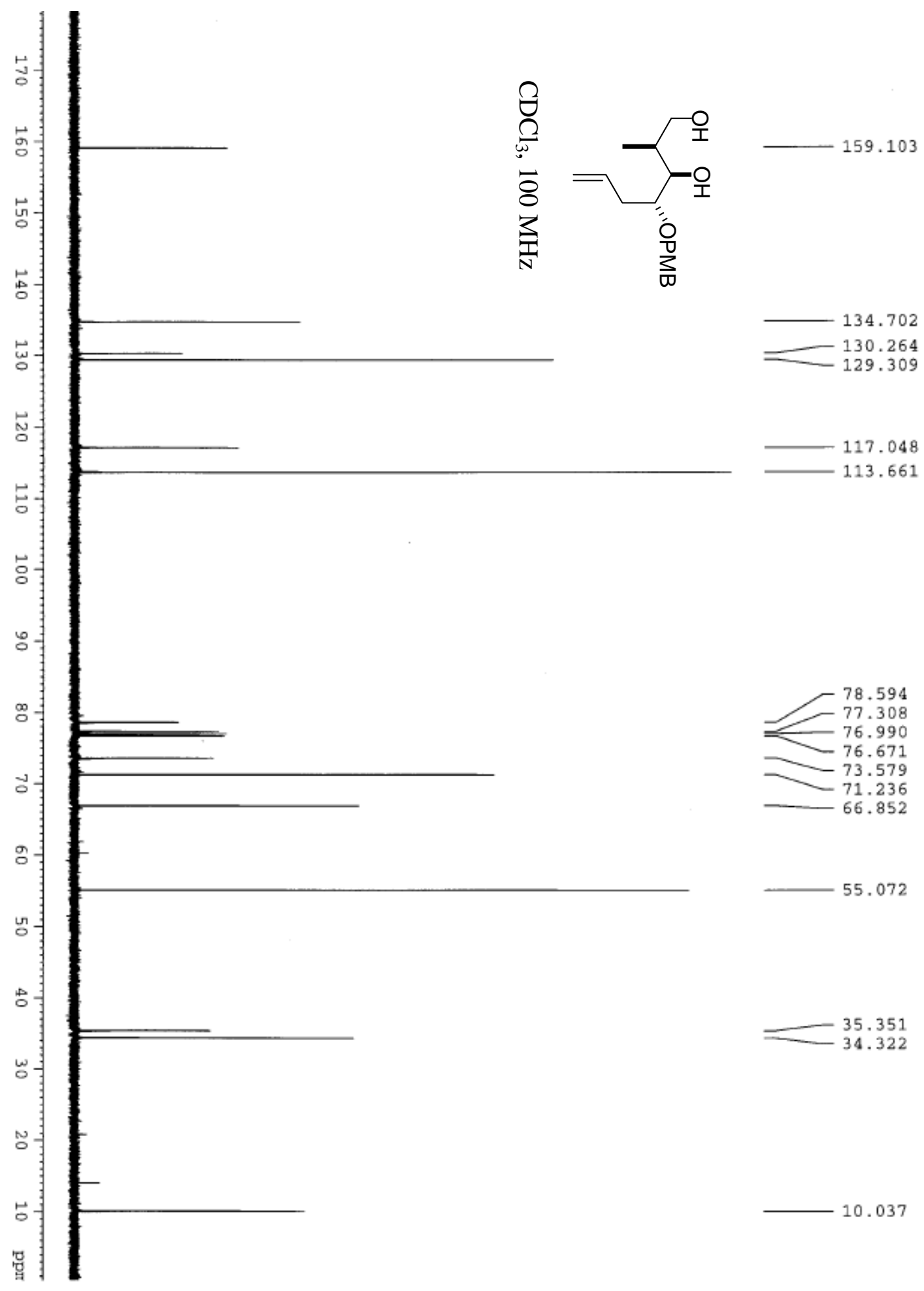

117.048 113.661
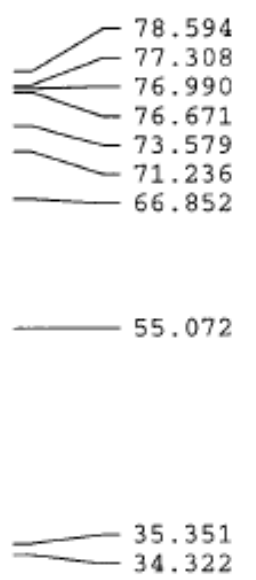

10.037 


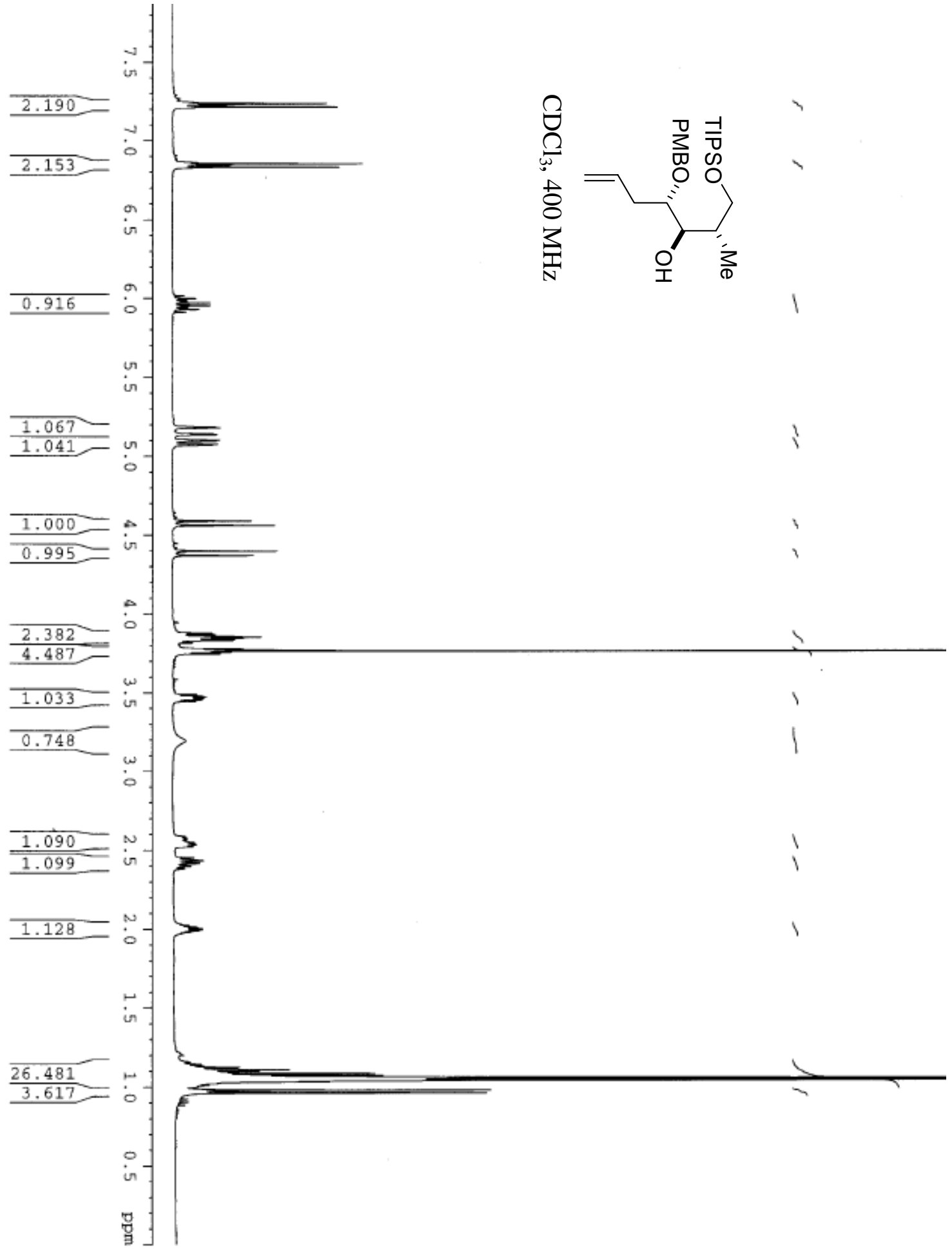



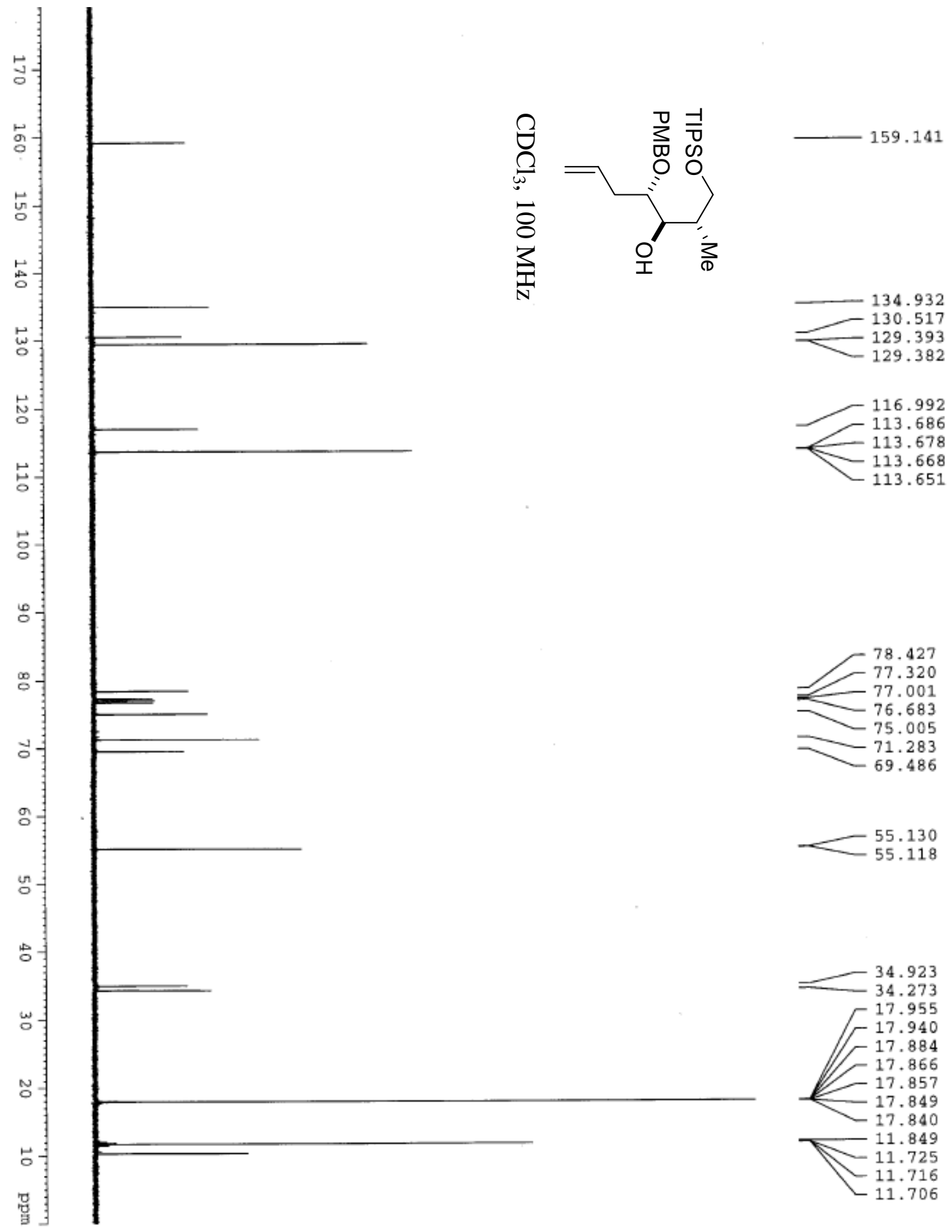
55.118

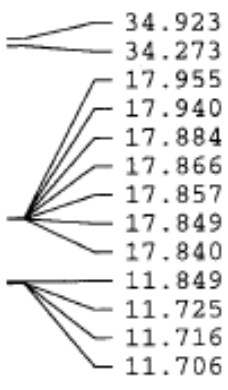




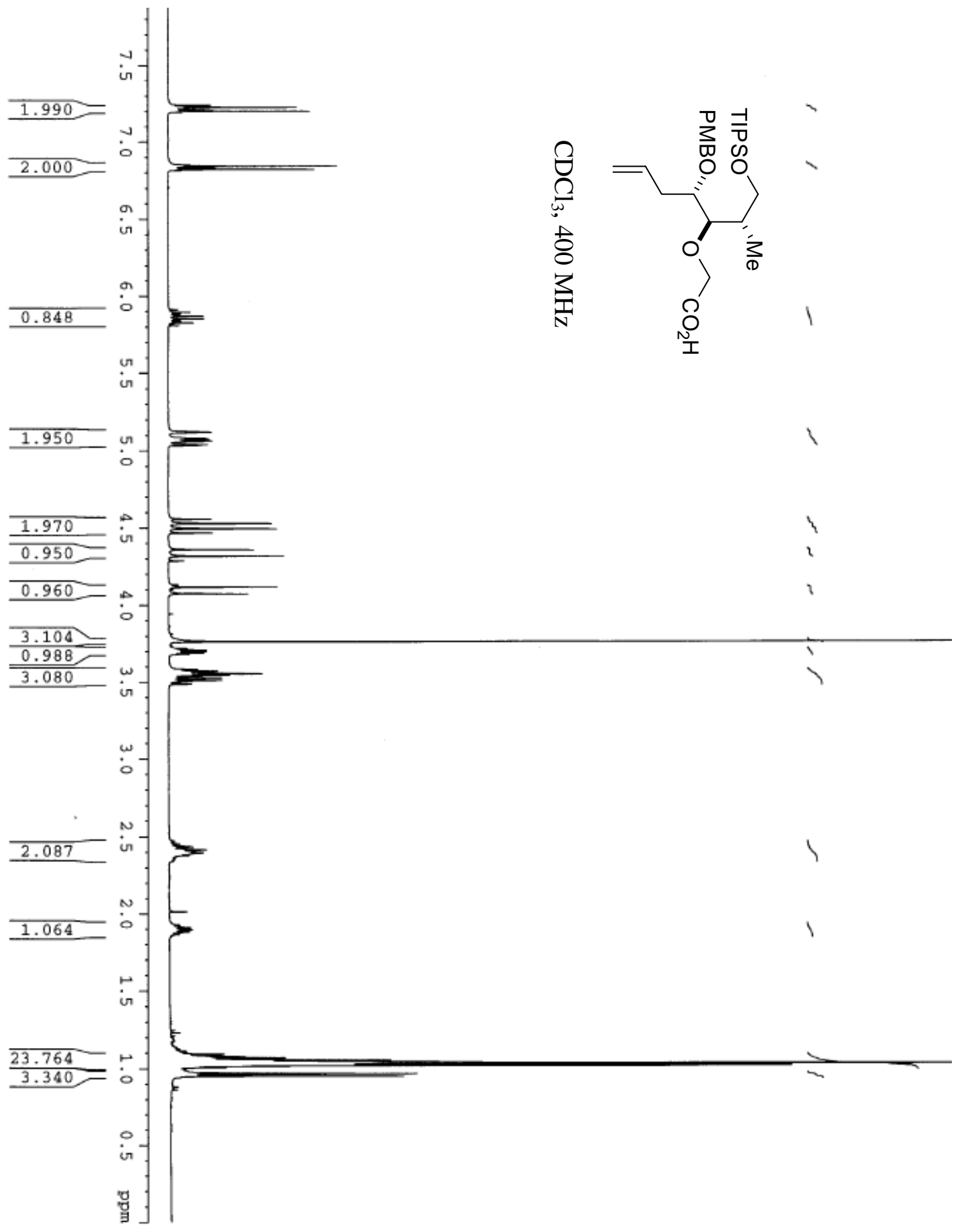



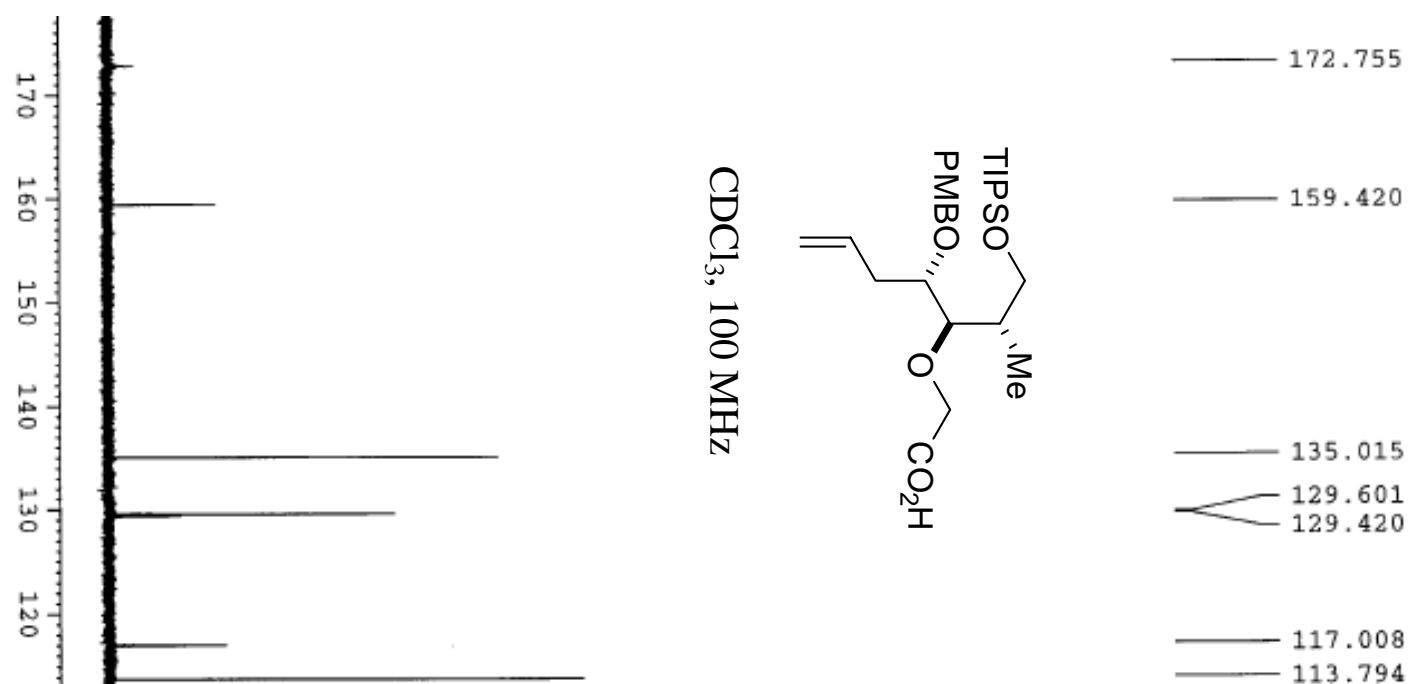

5

홍

○

$\circ$

당

용

n

\&

w

응

ㄴ

橎
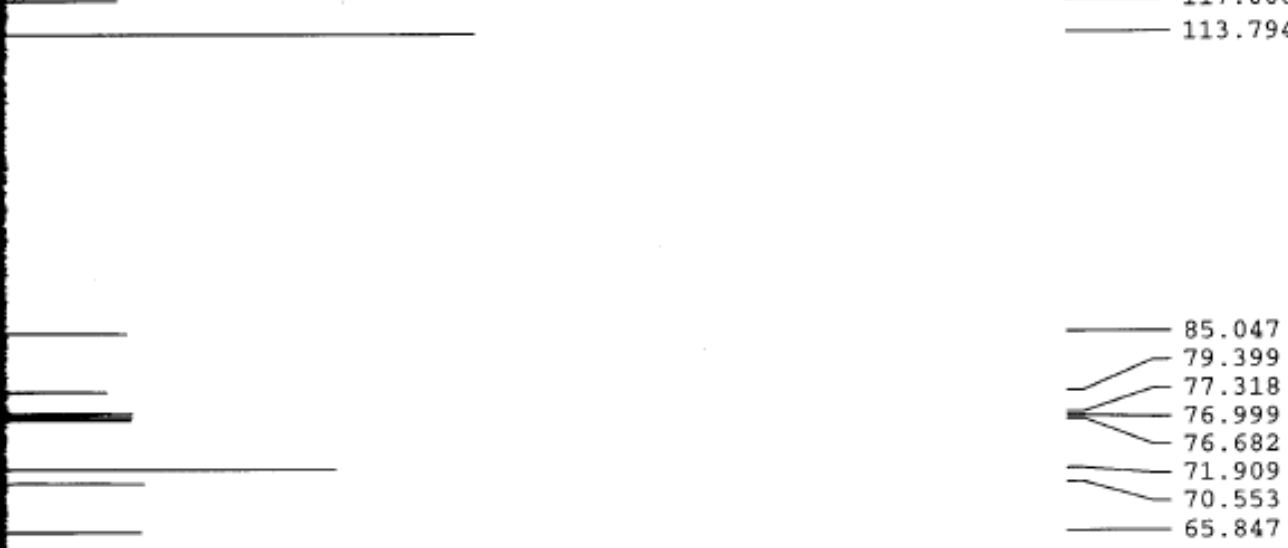

$-55.107$

33.999

。

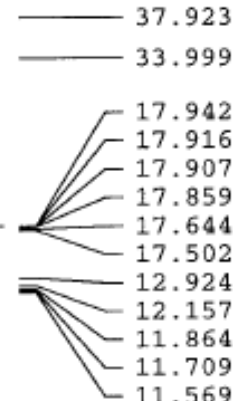




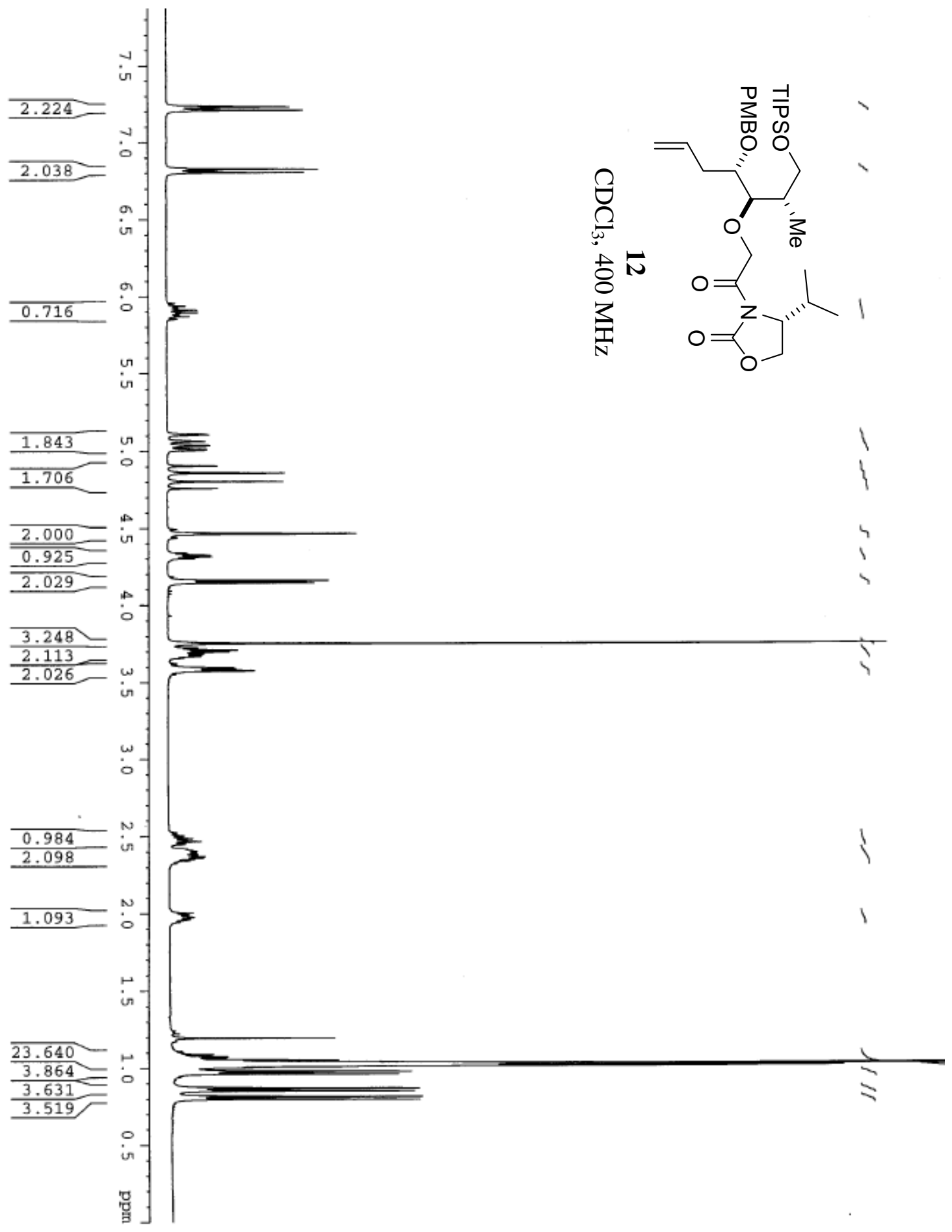




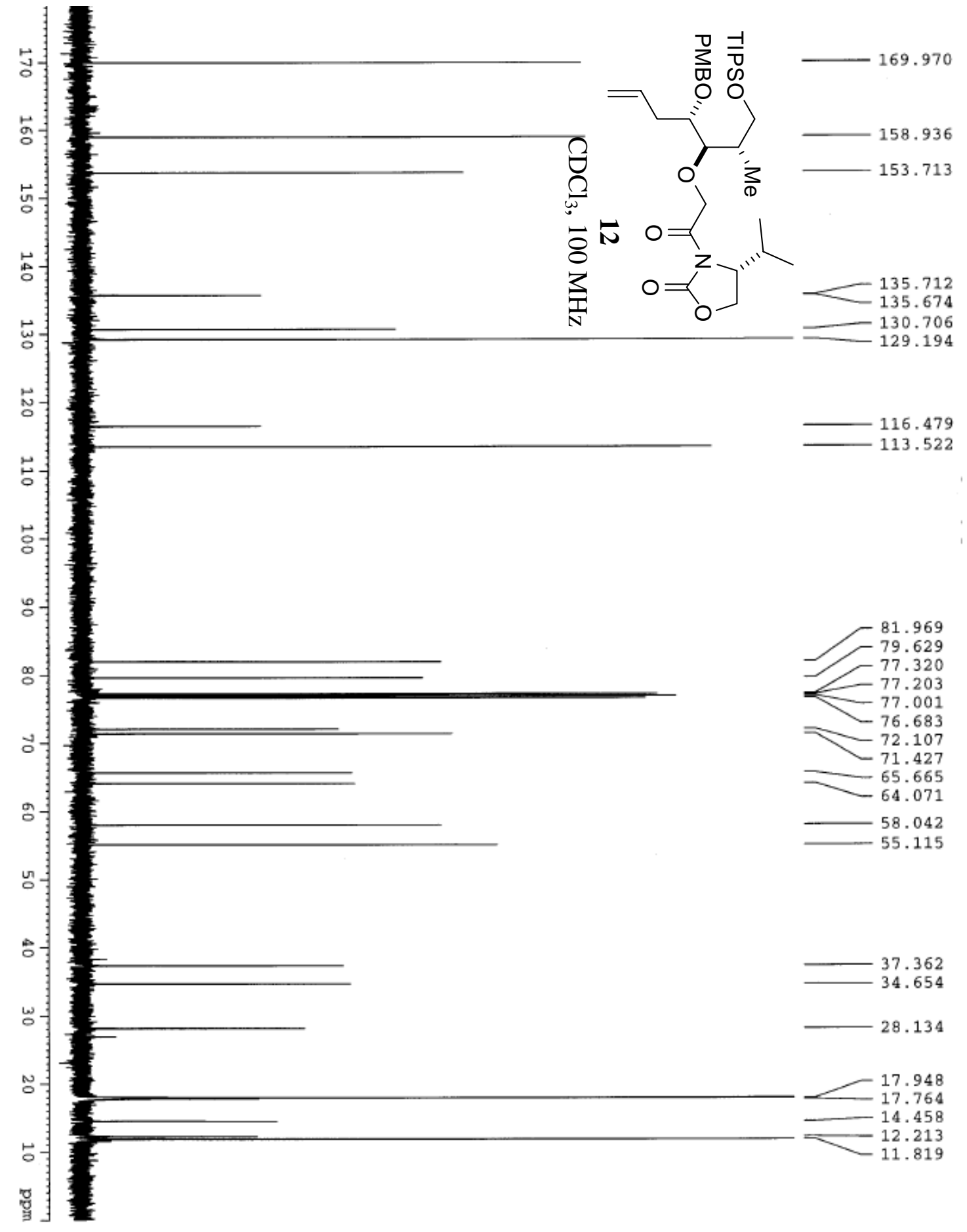




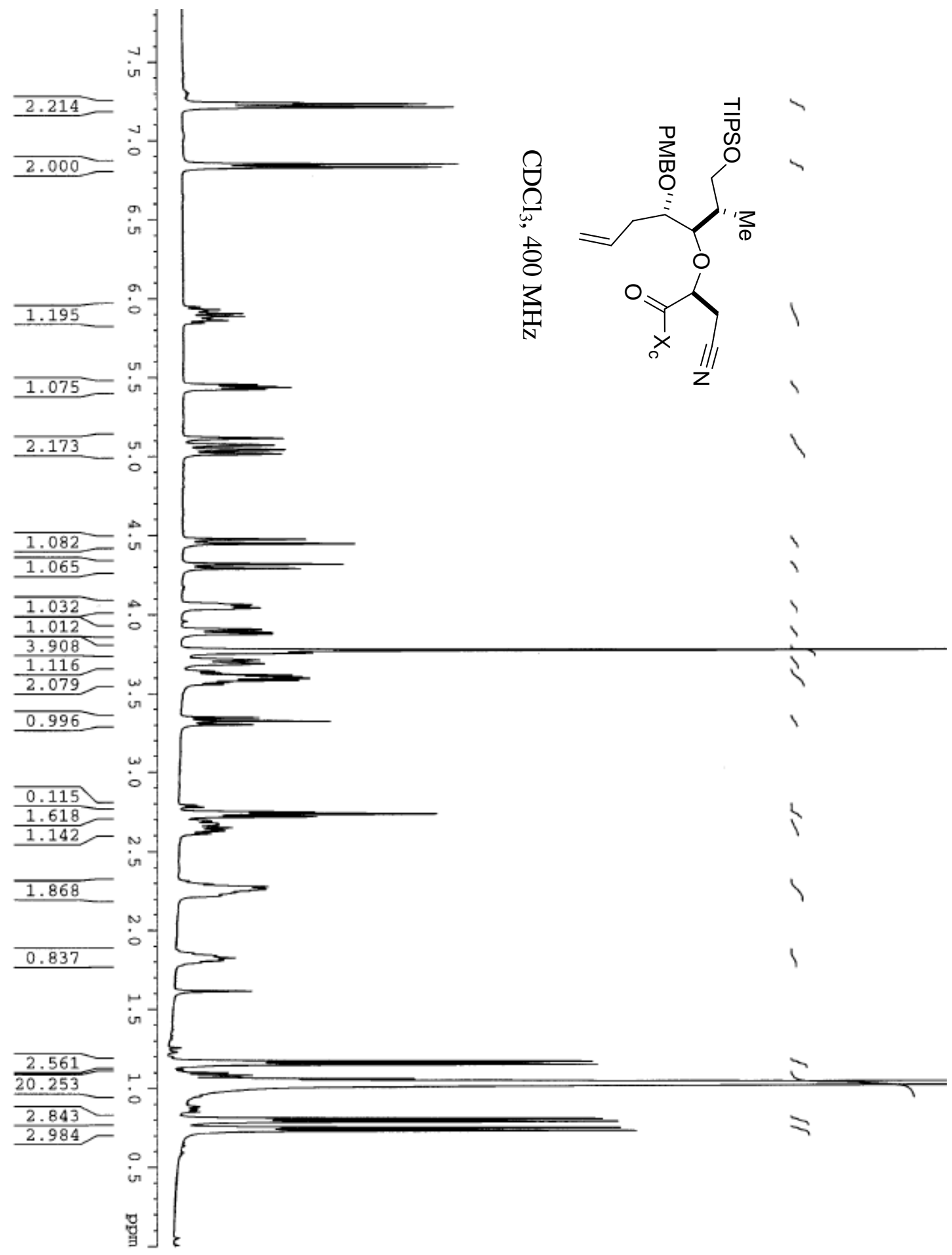




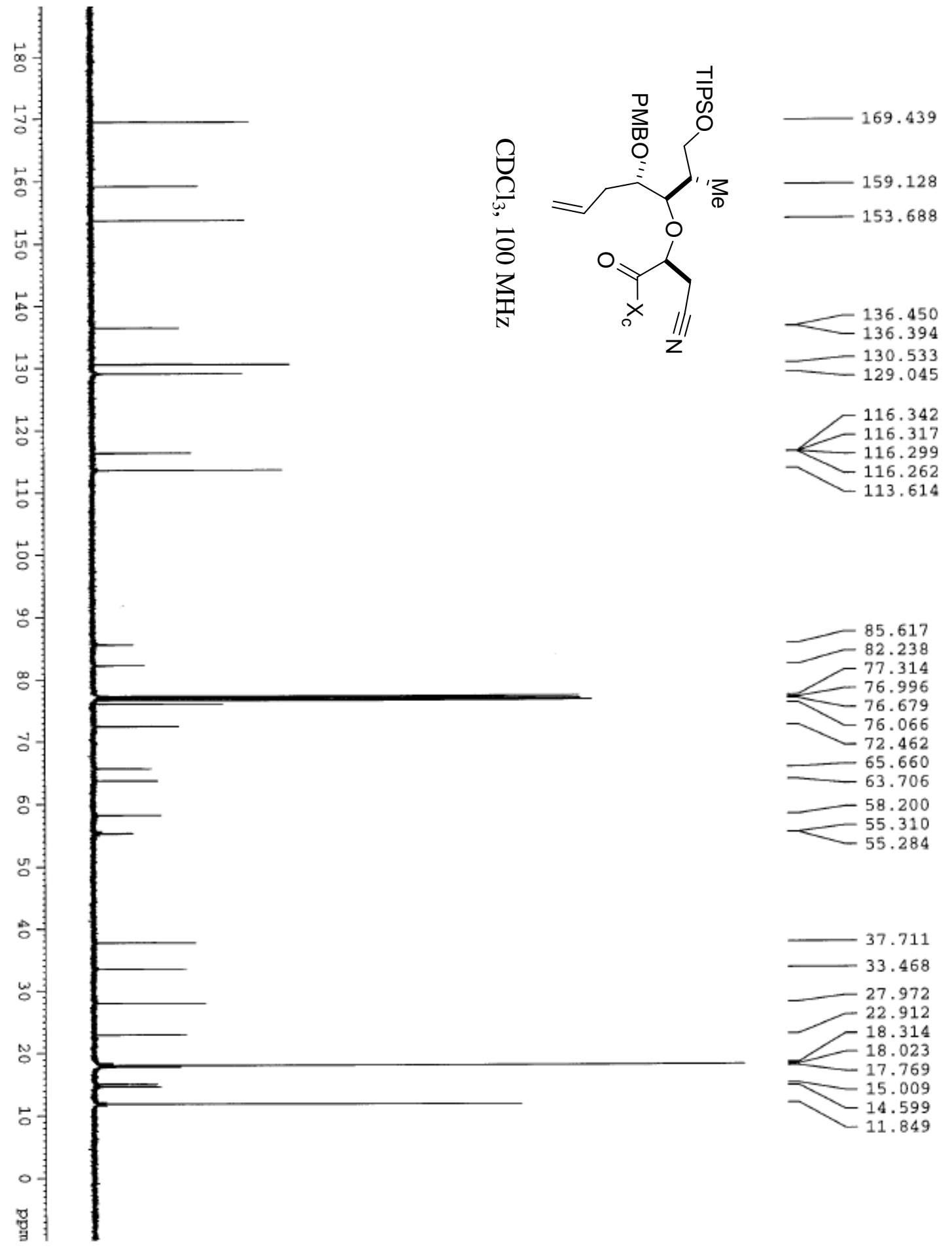




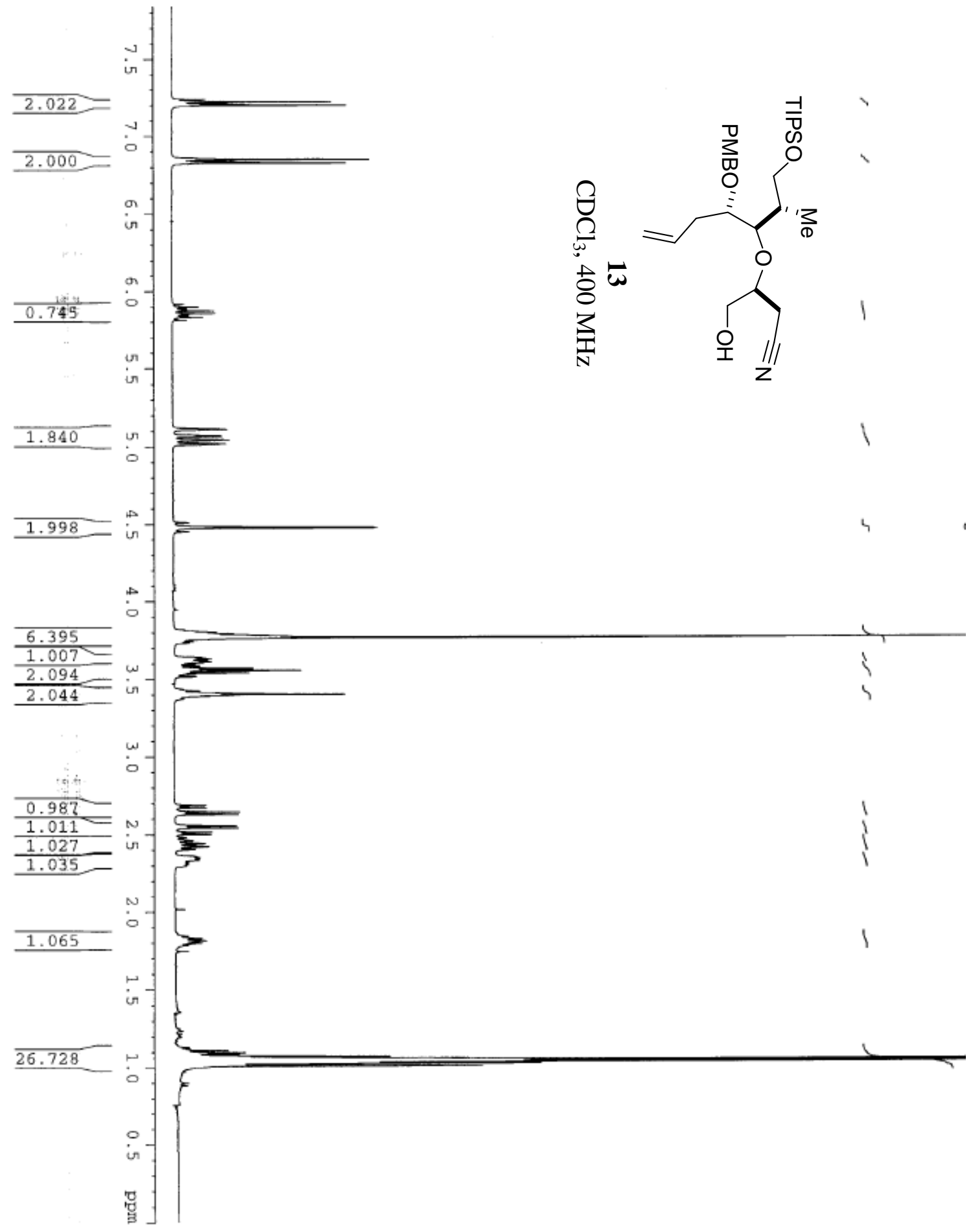




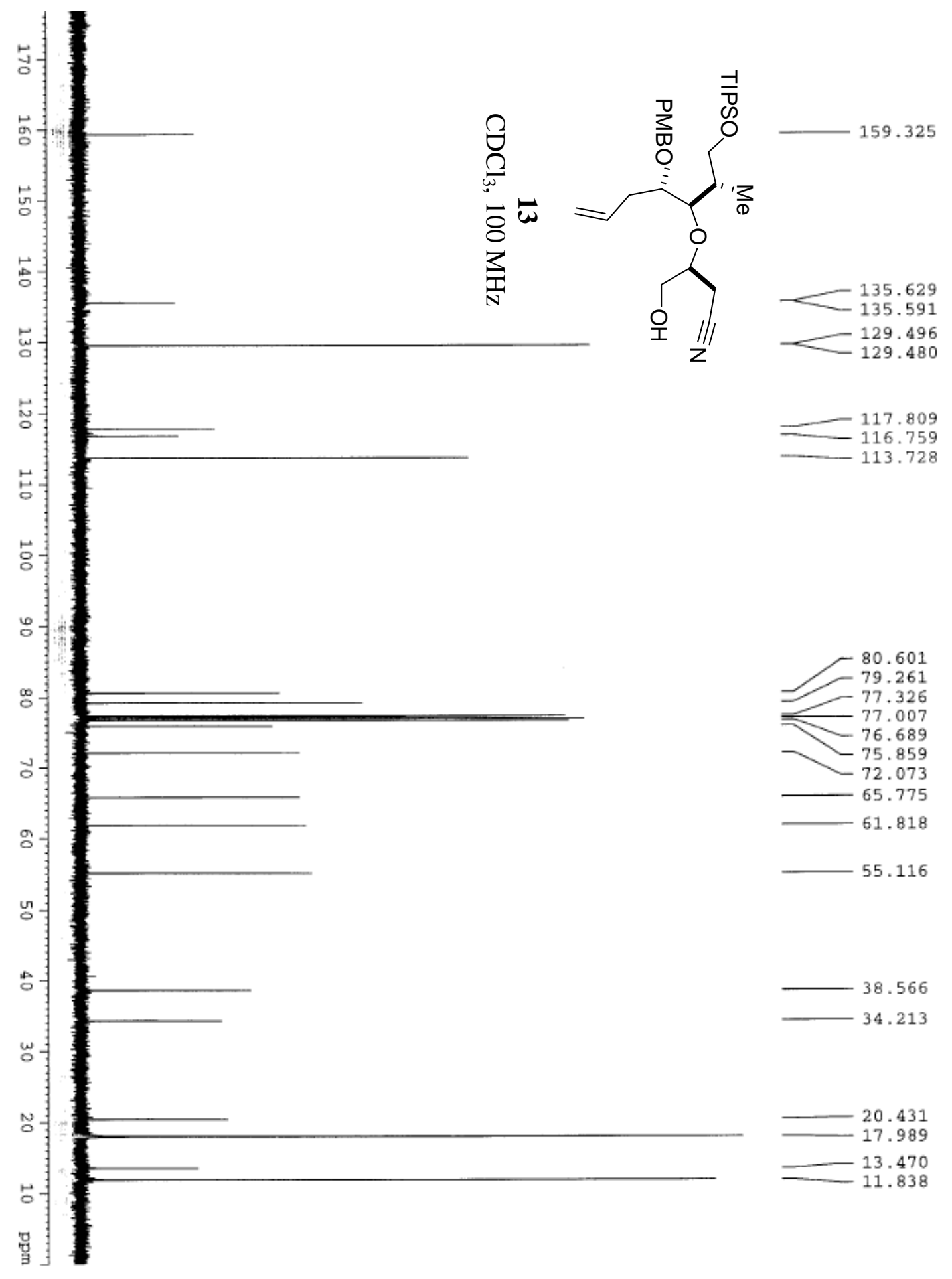




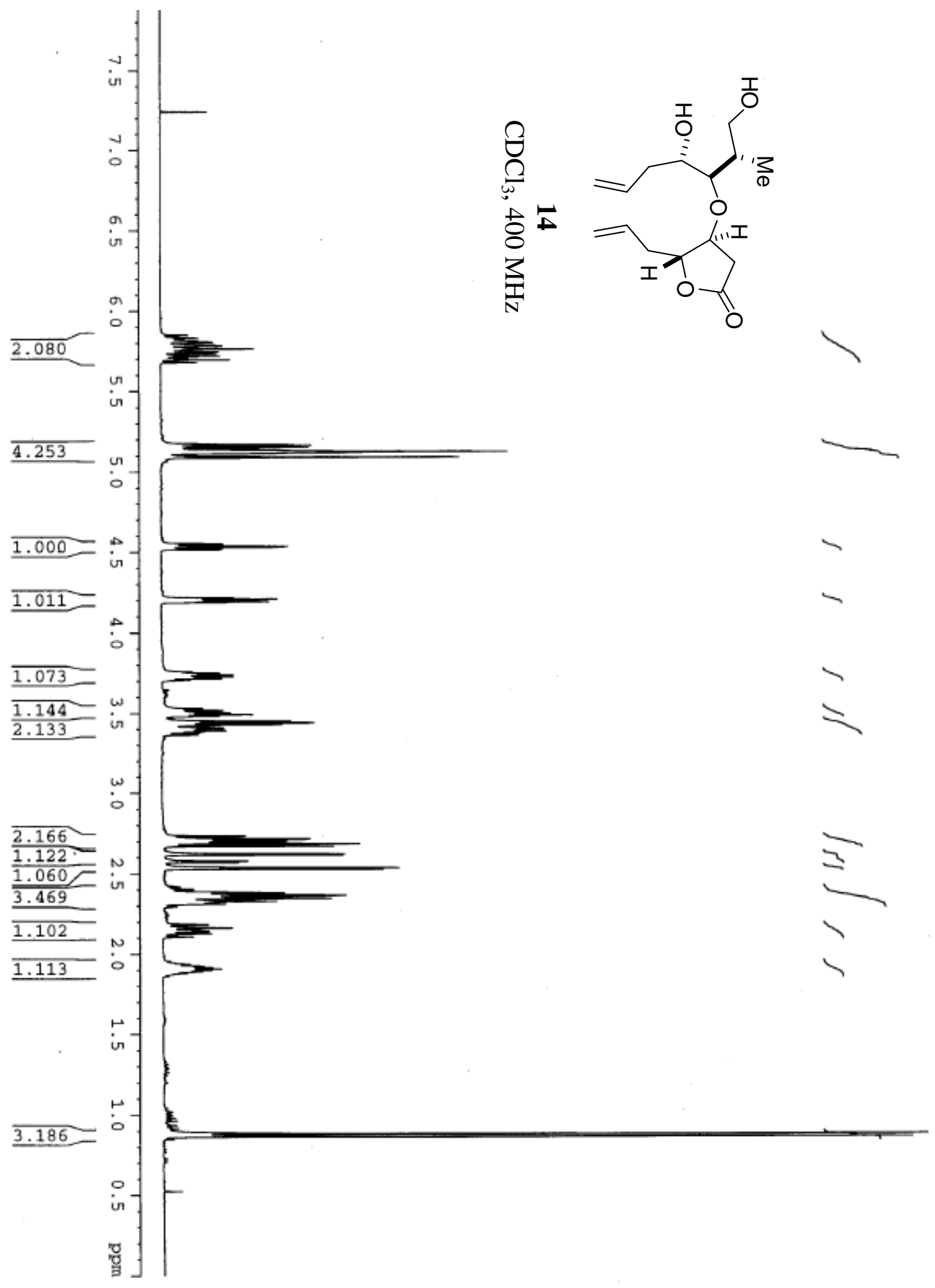



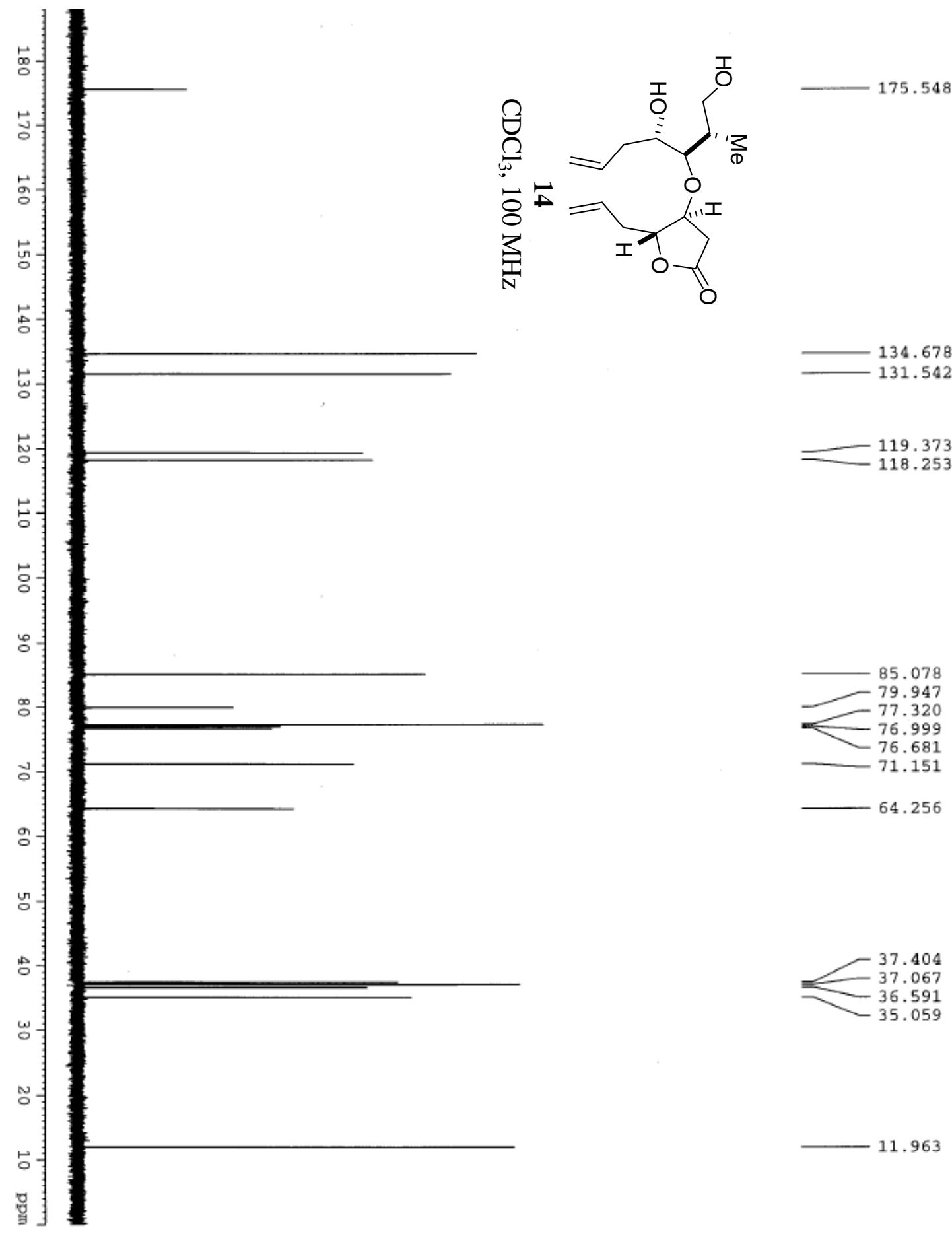

37. 404 37.067 36.591

35.059

11.963 


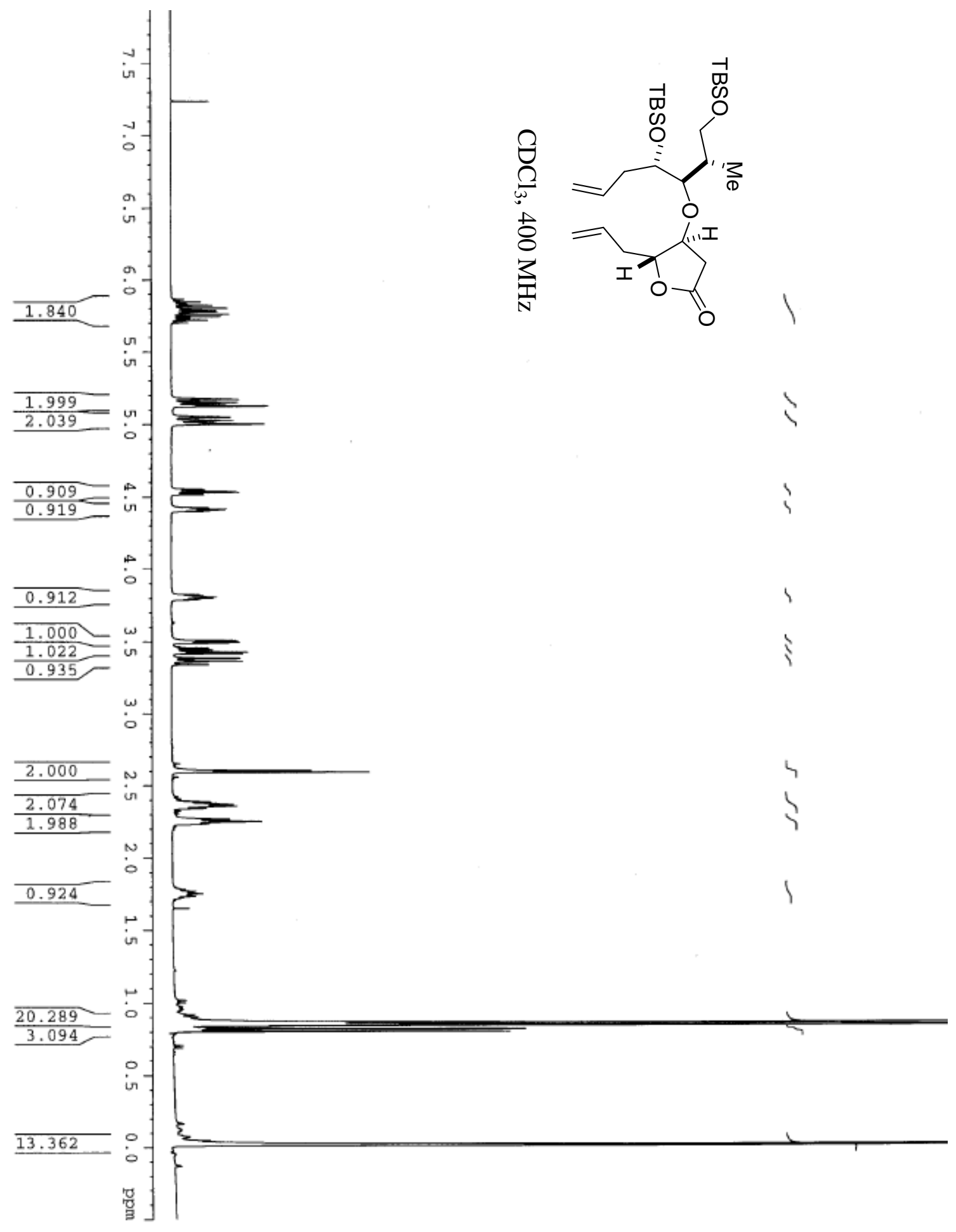




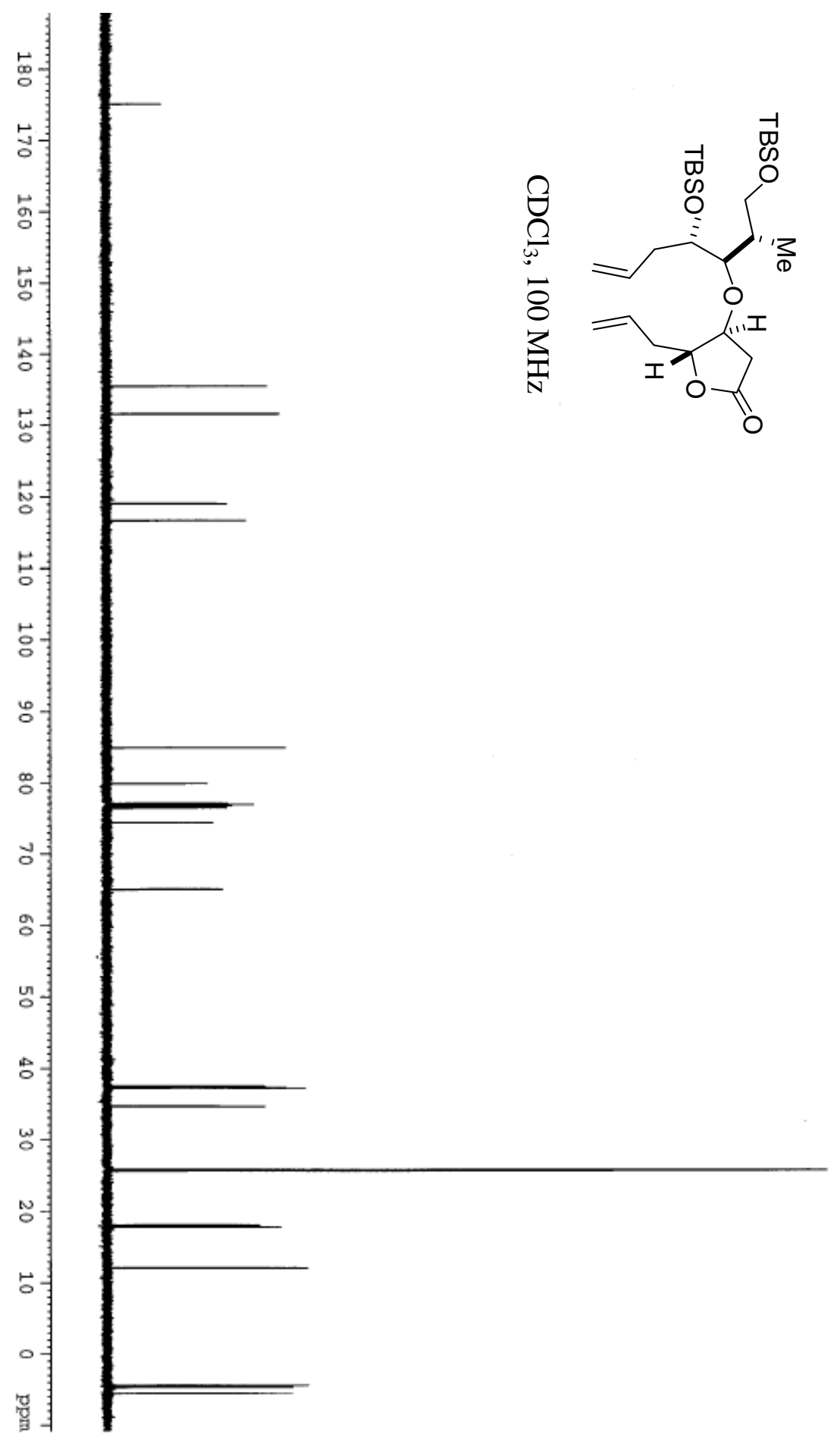

$-175.060$
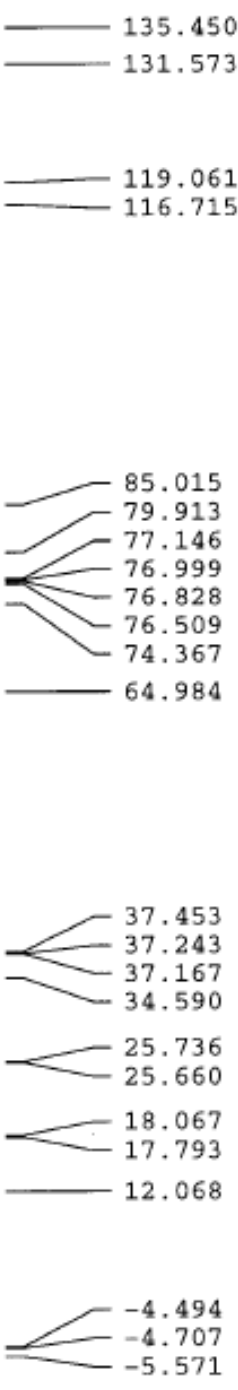


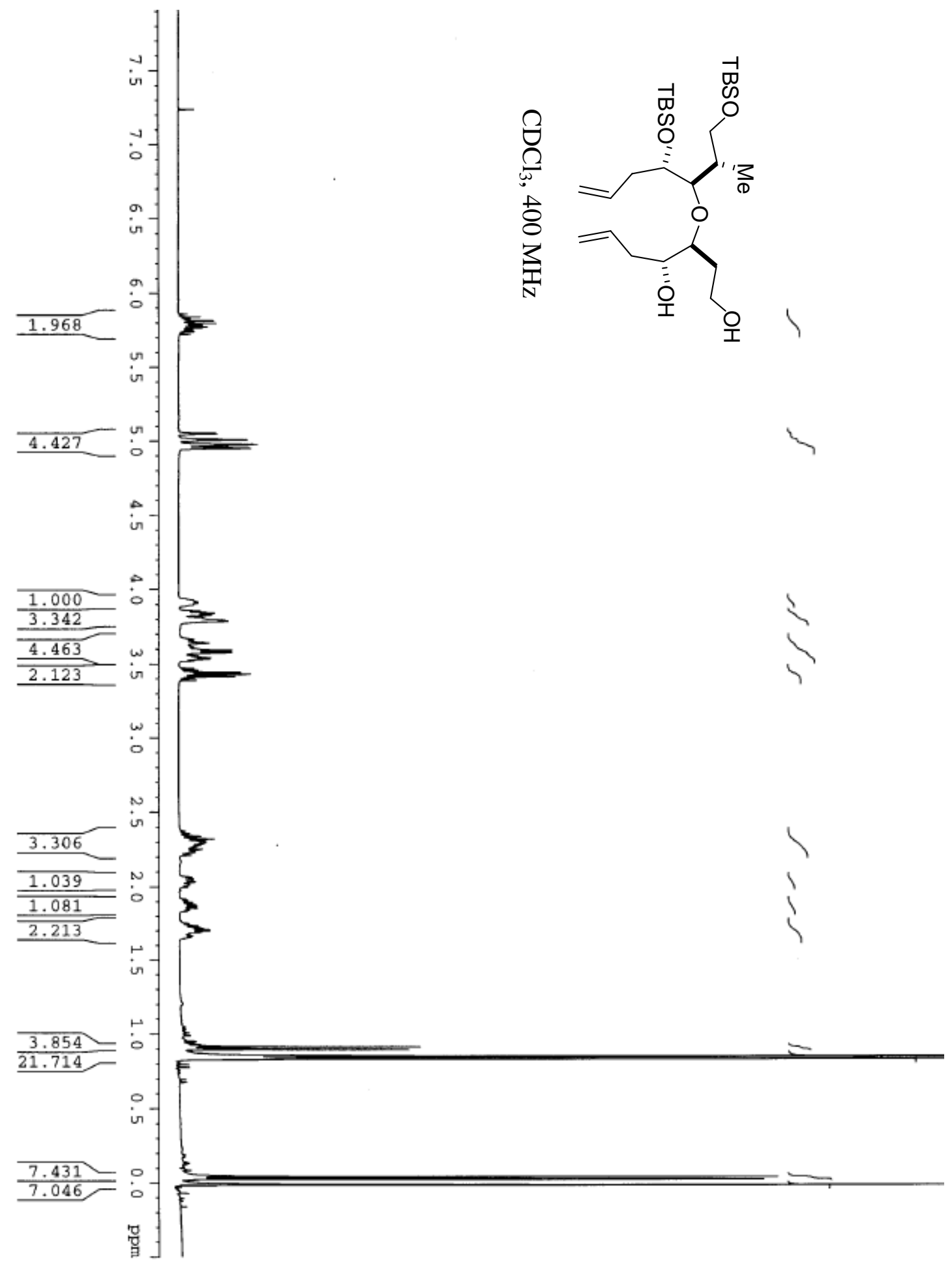




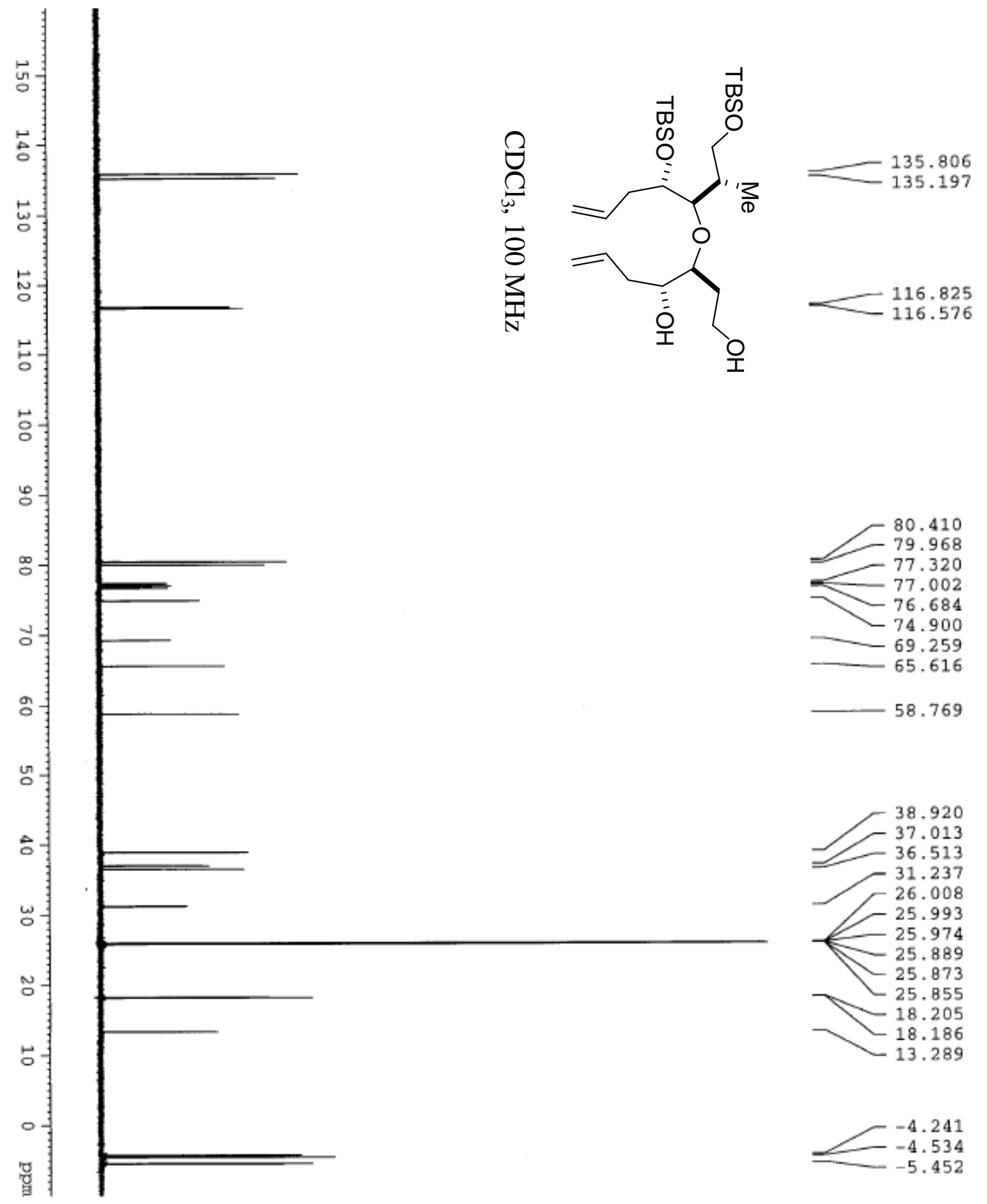




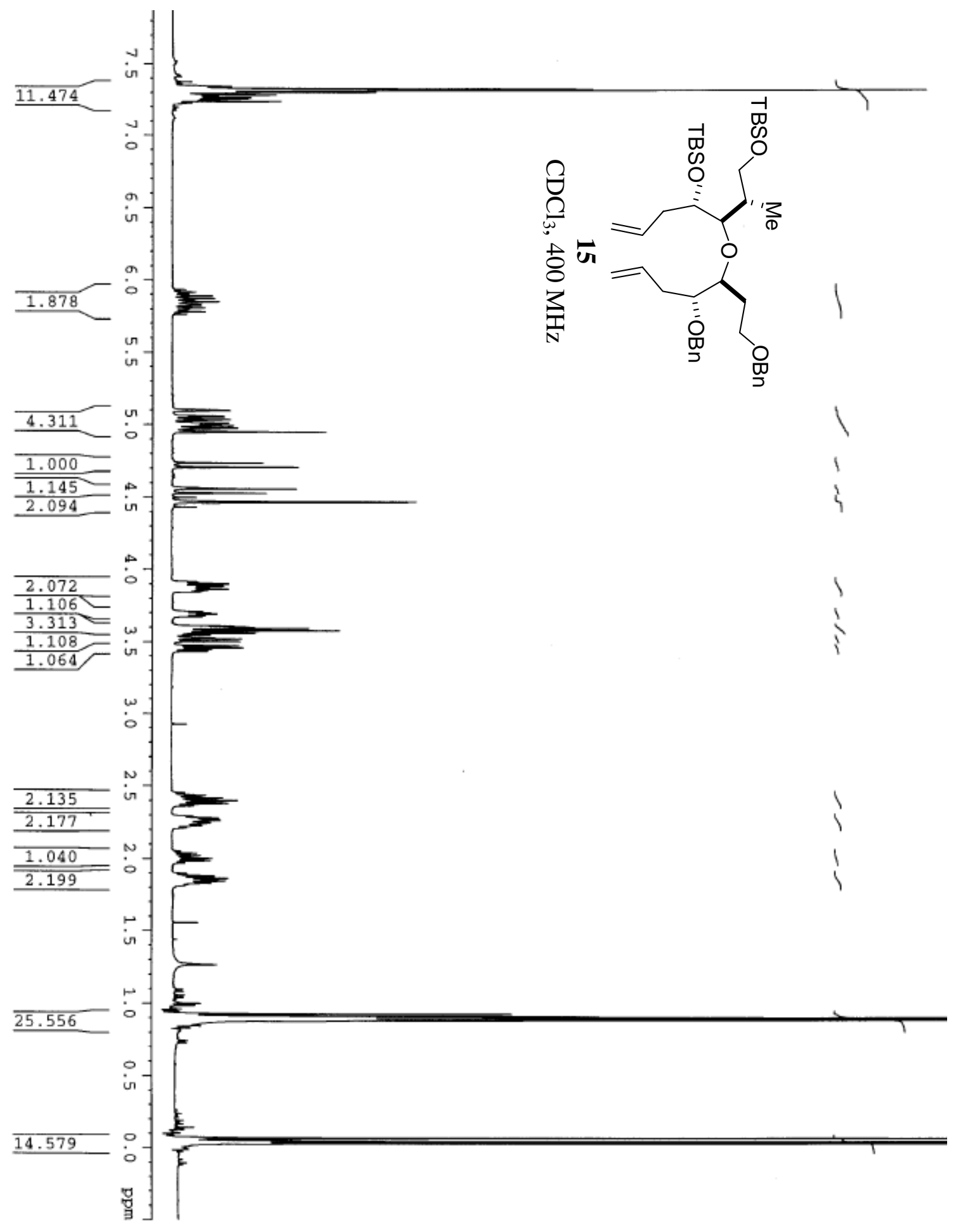



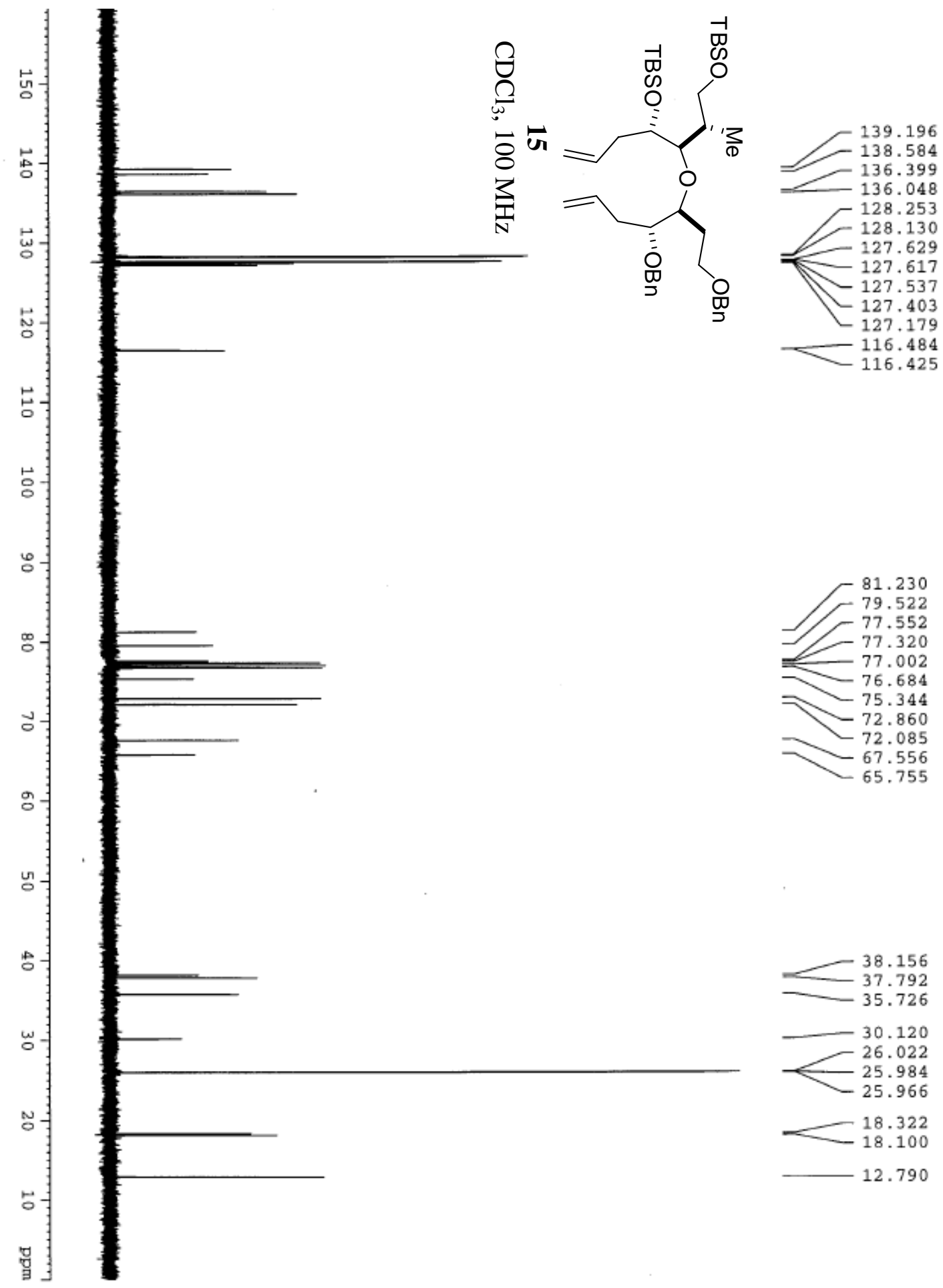

37.792

30.120

26.022

25.984

18.322

18.100

12.790 


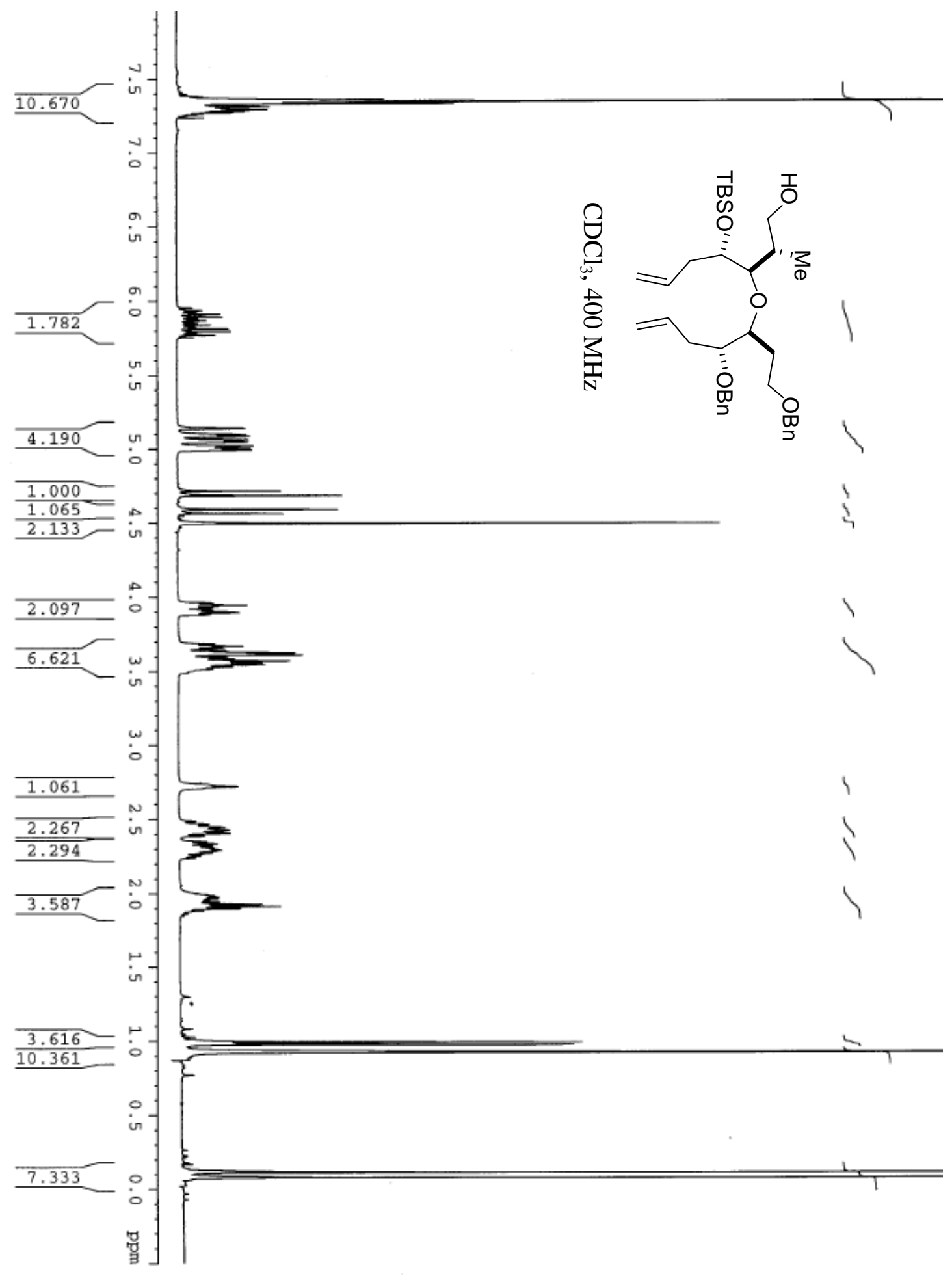



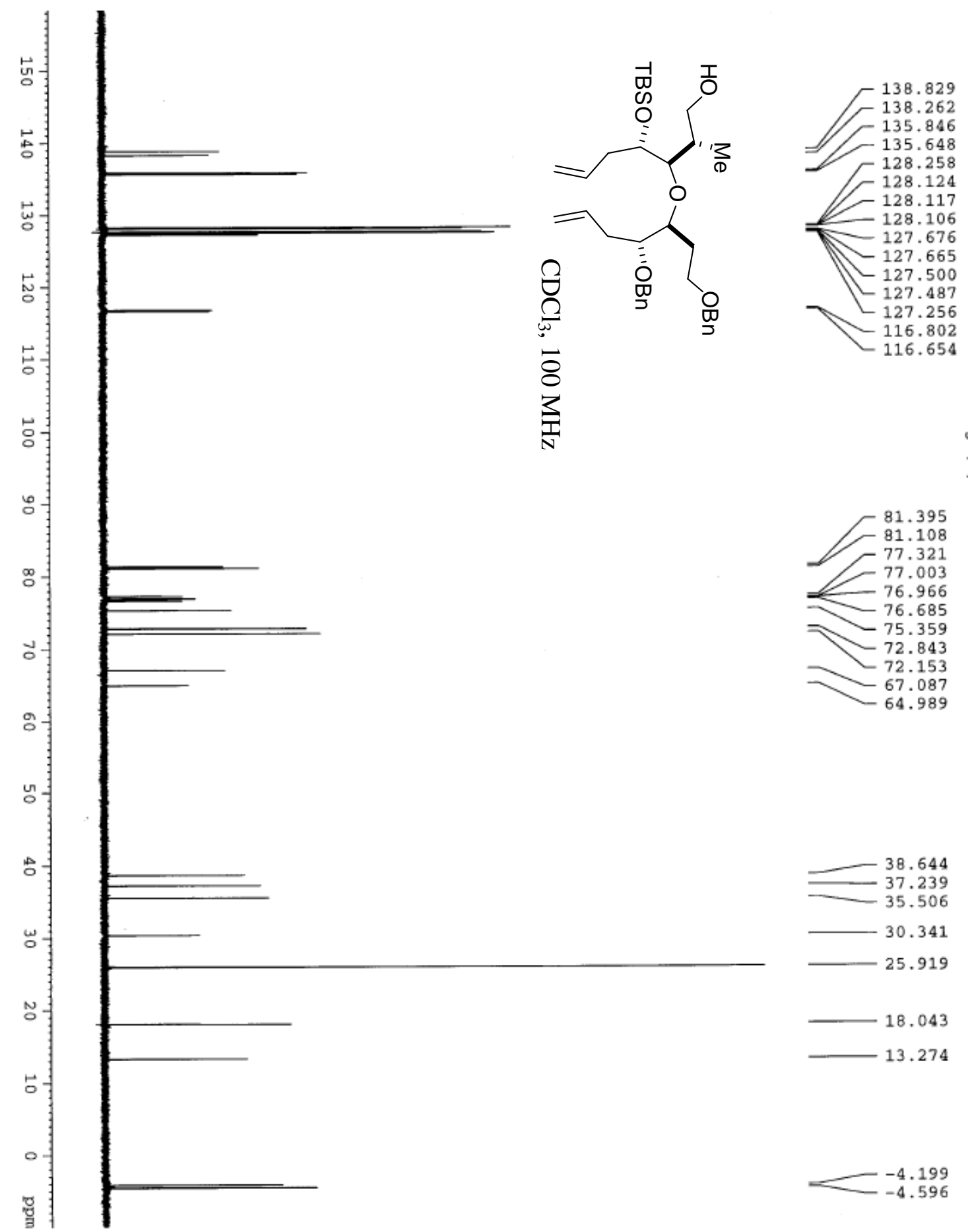


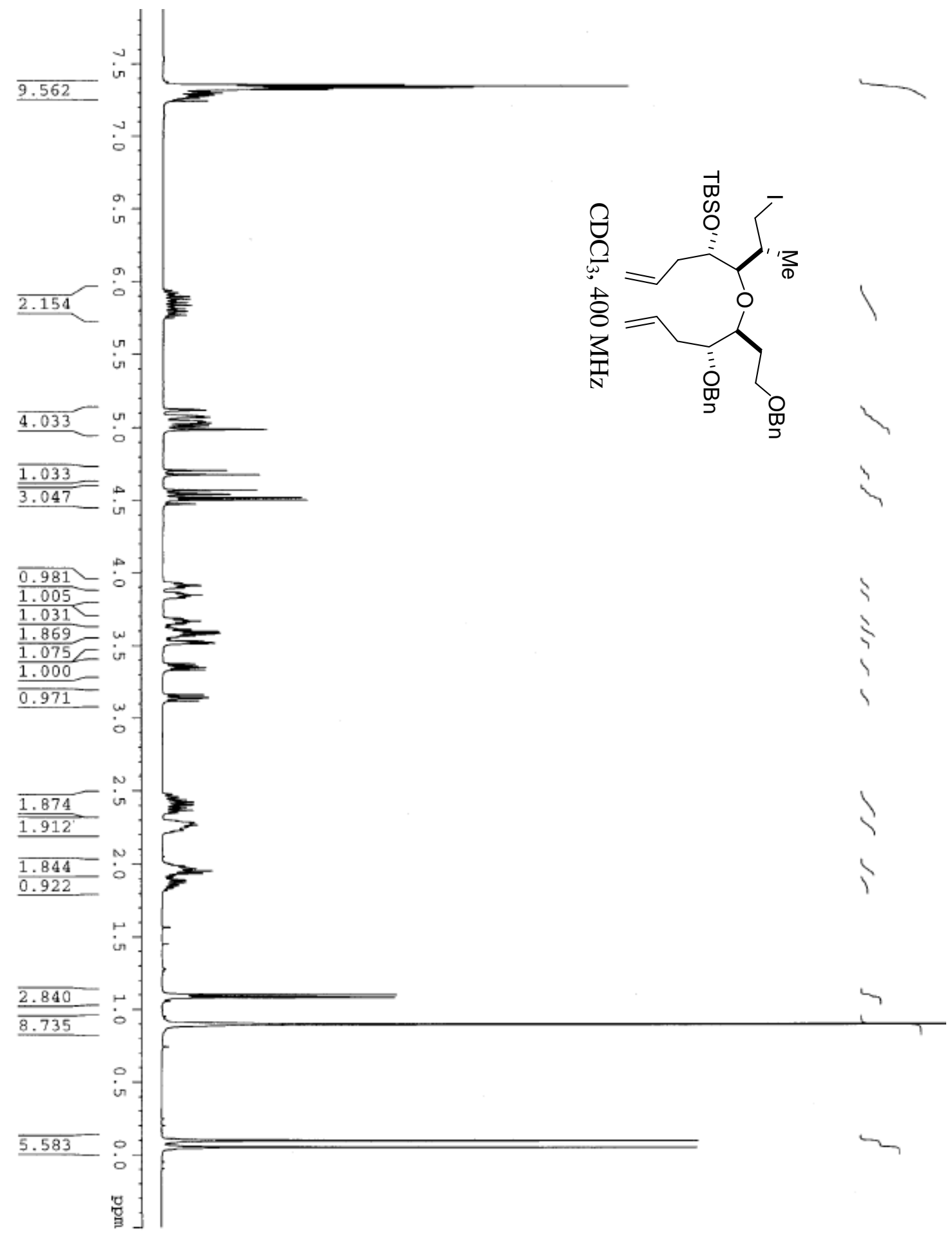




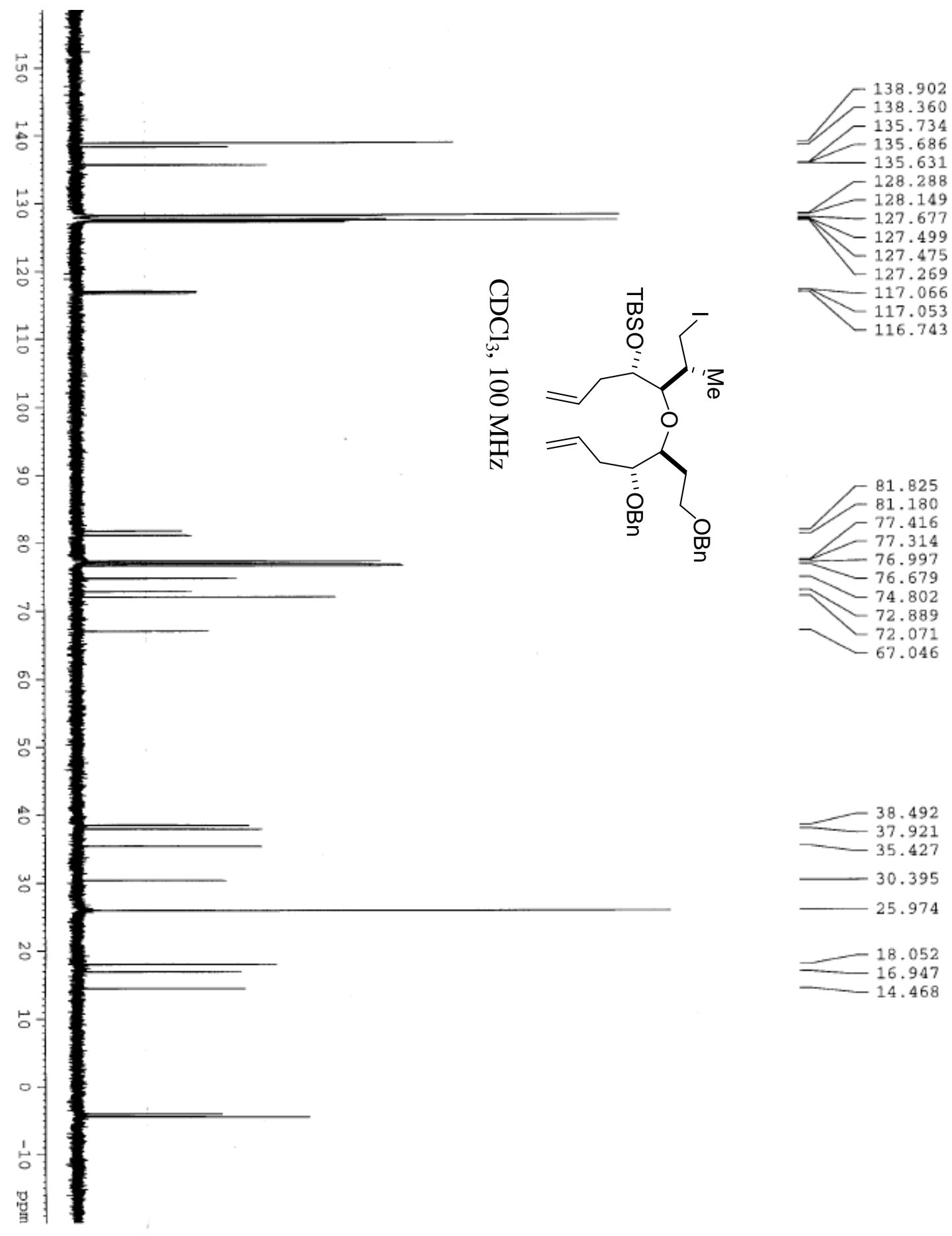




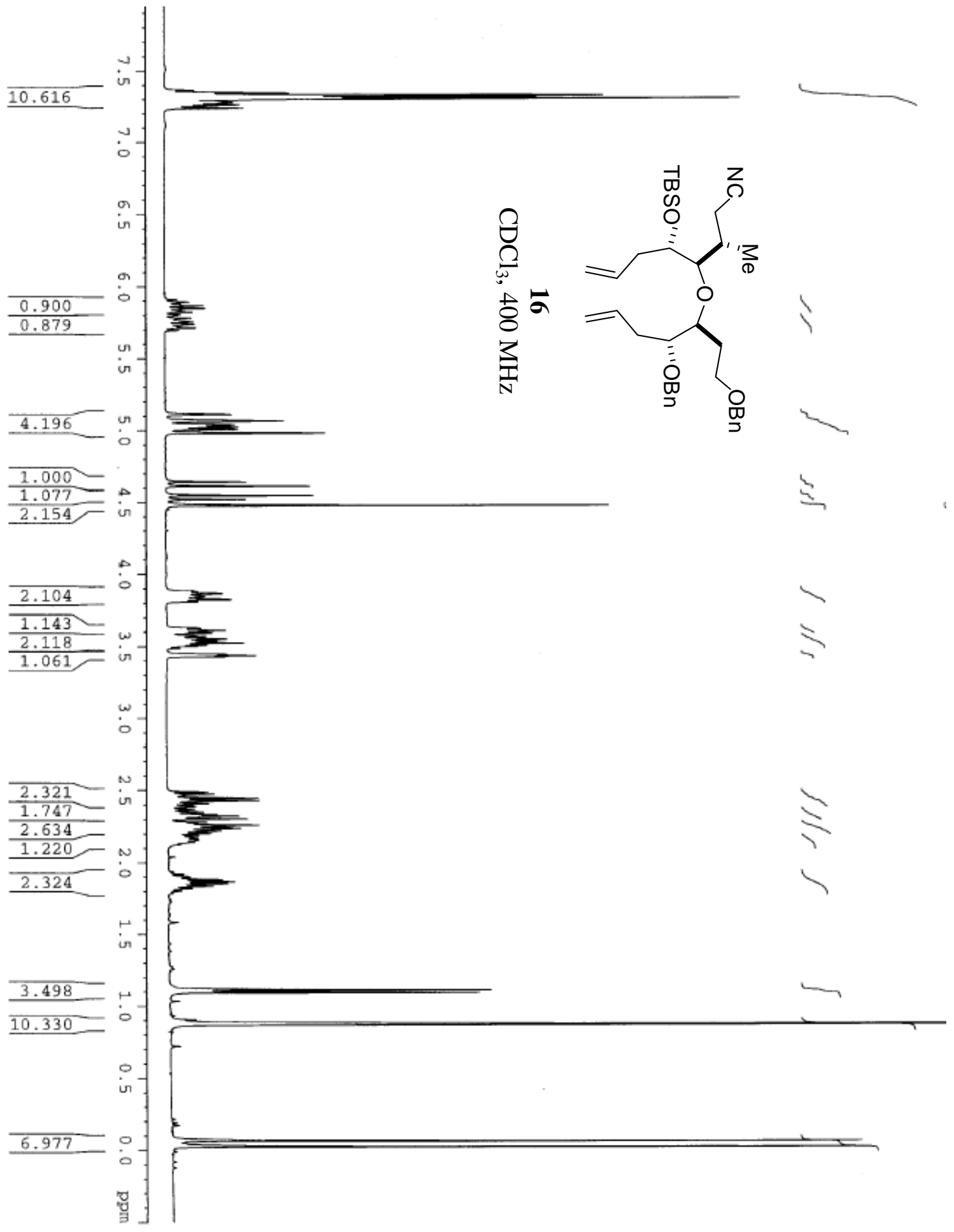



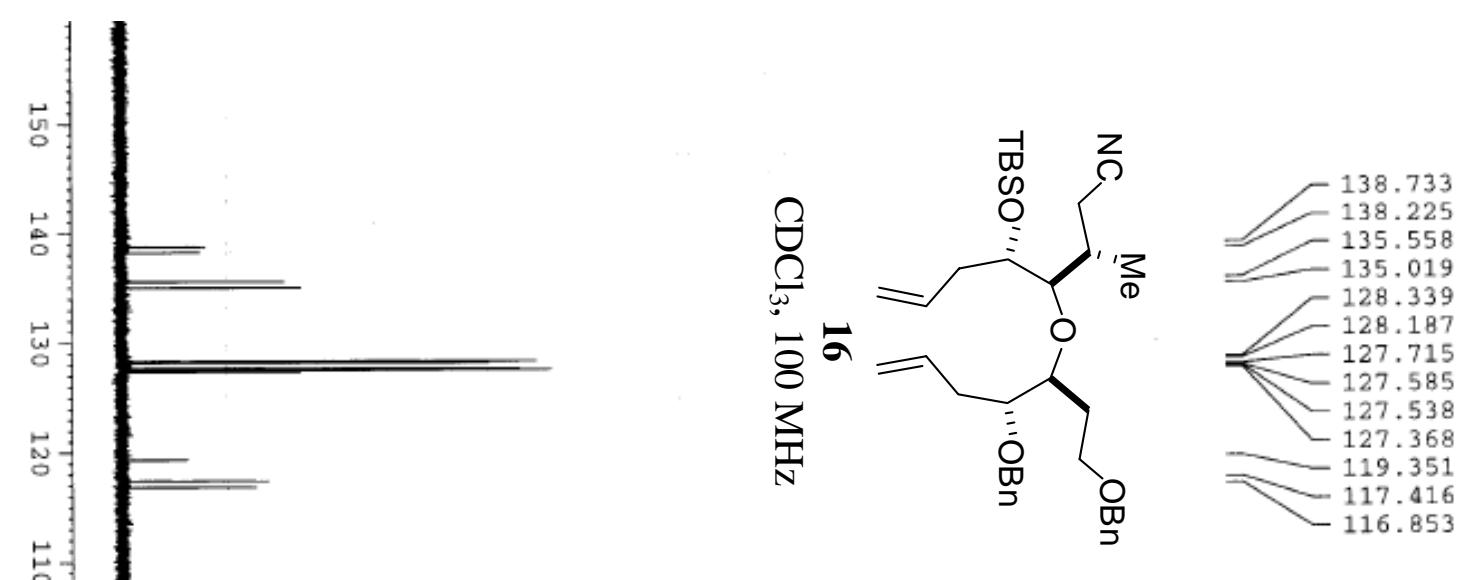

응

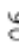

s

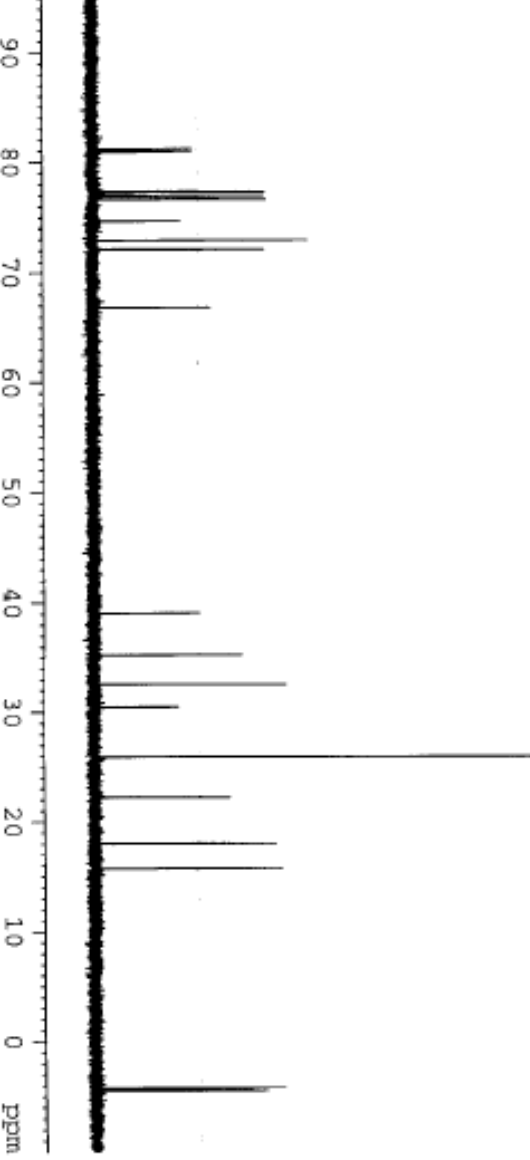

s.

ต

둑

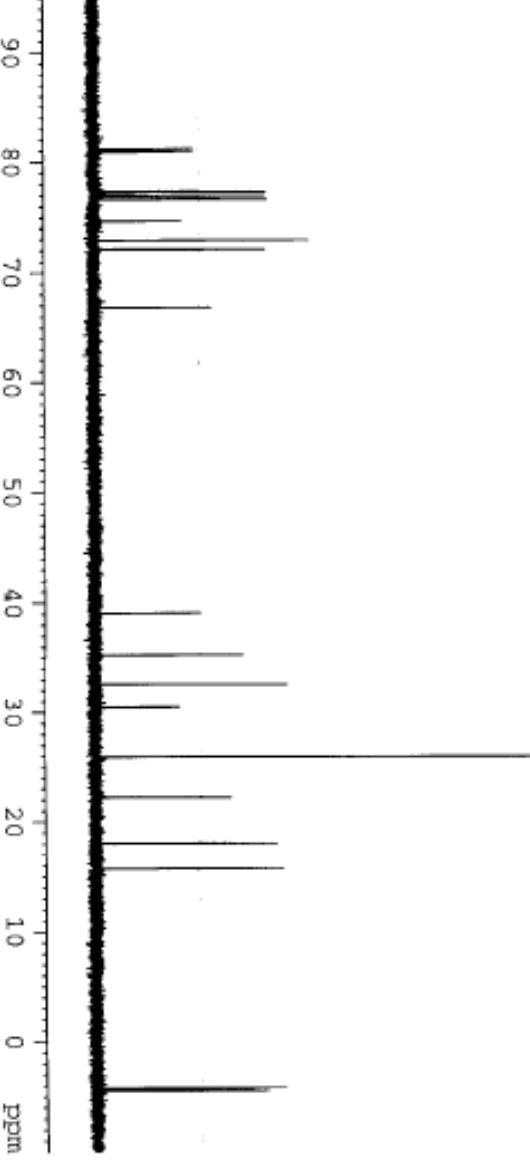

w.

N-

$\circ$
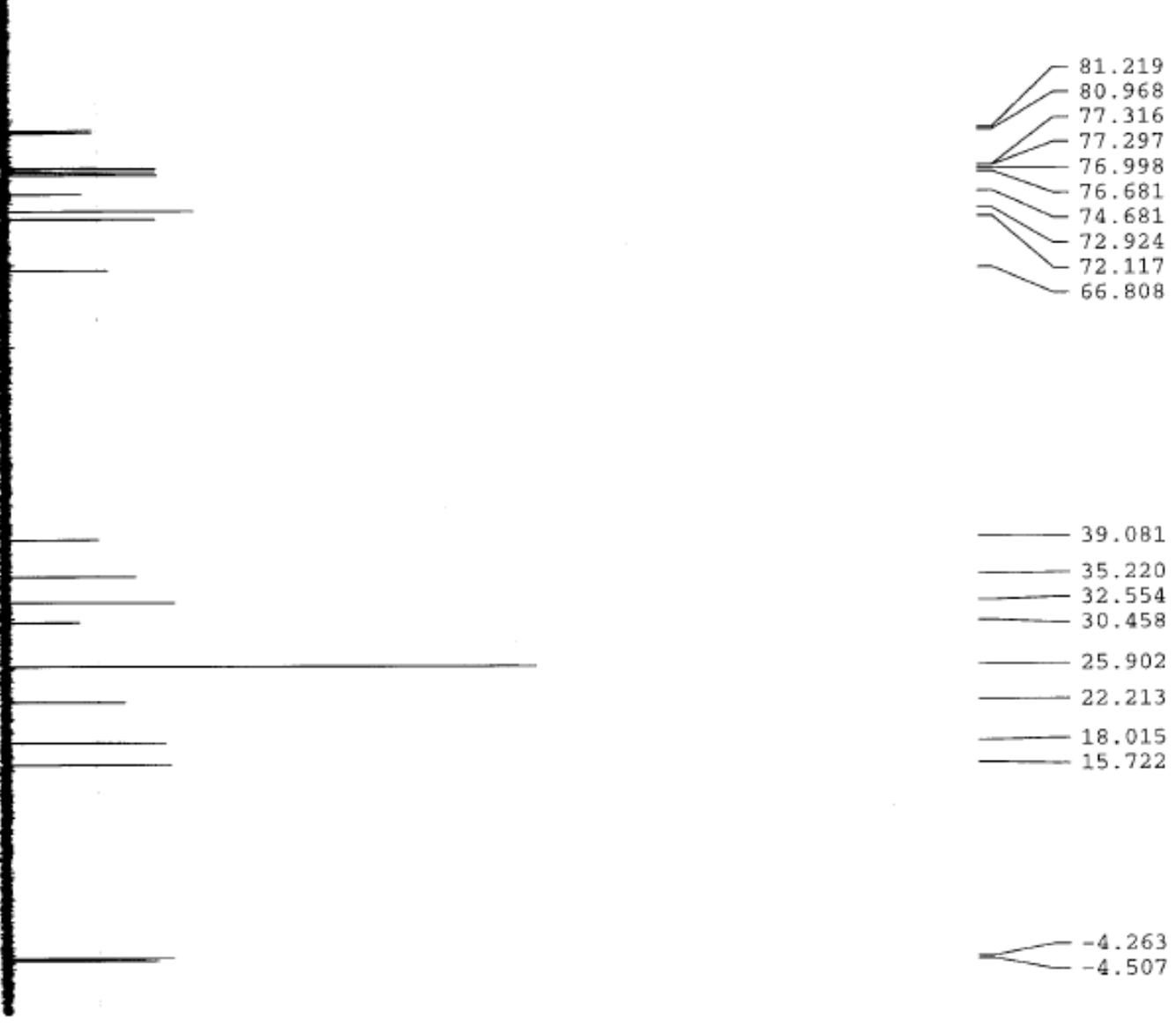

它

$\circ-$

莺
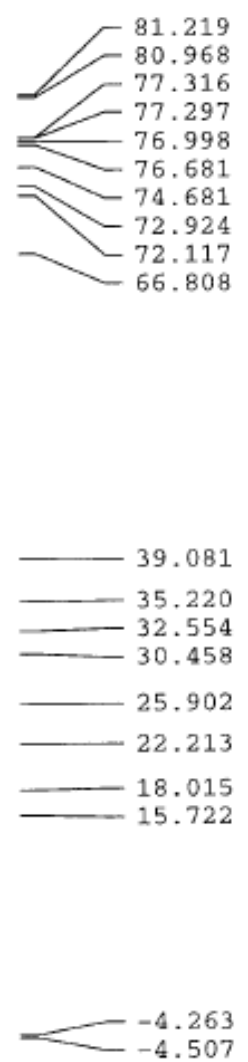


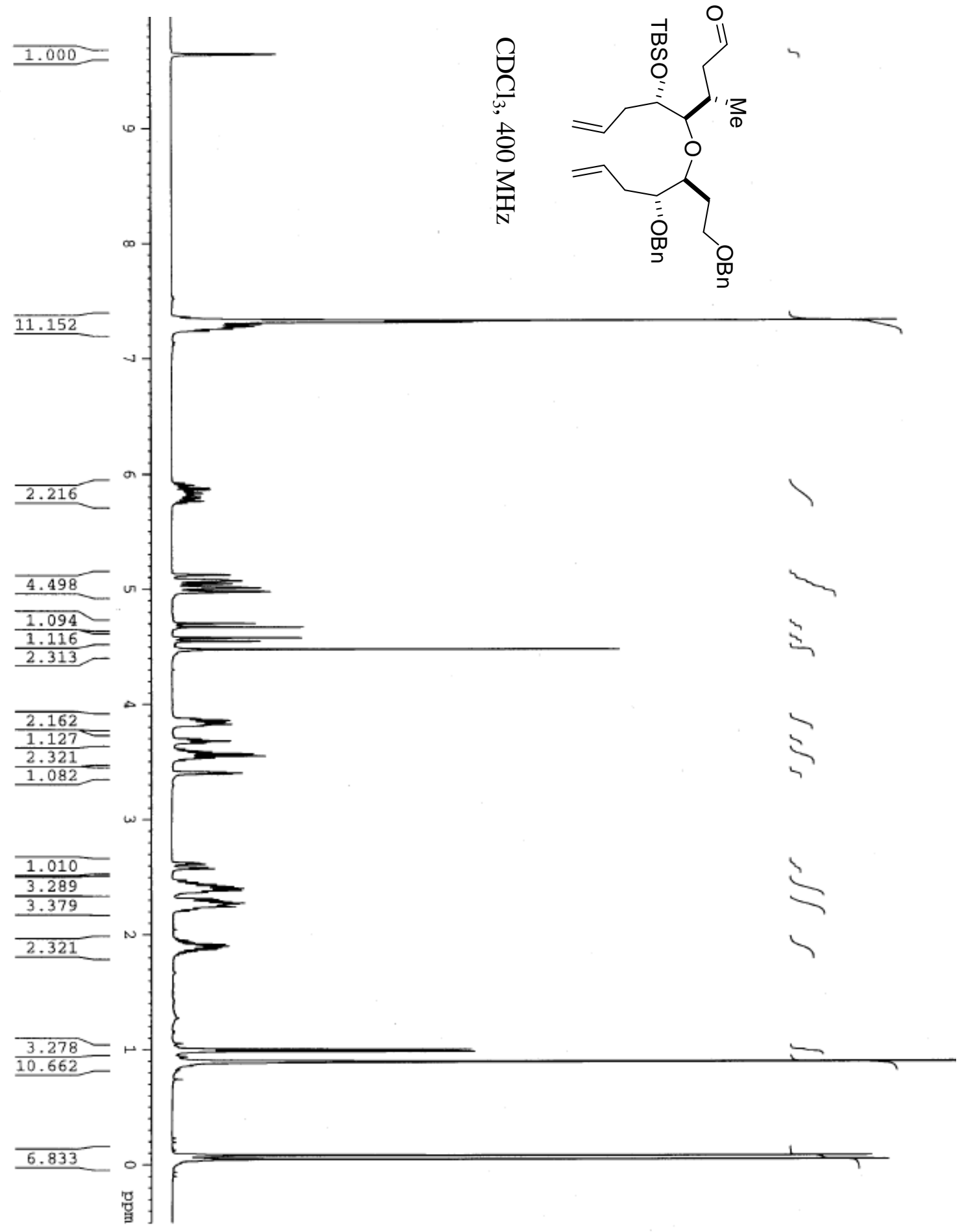




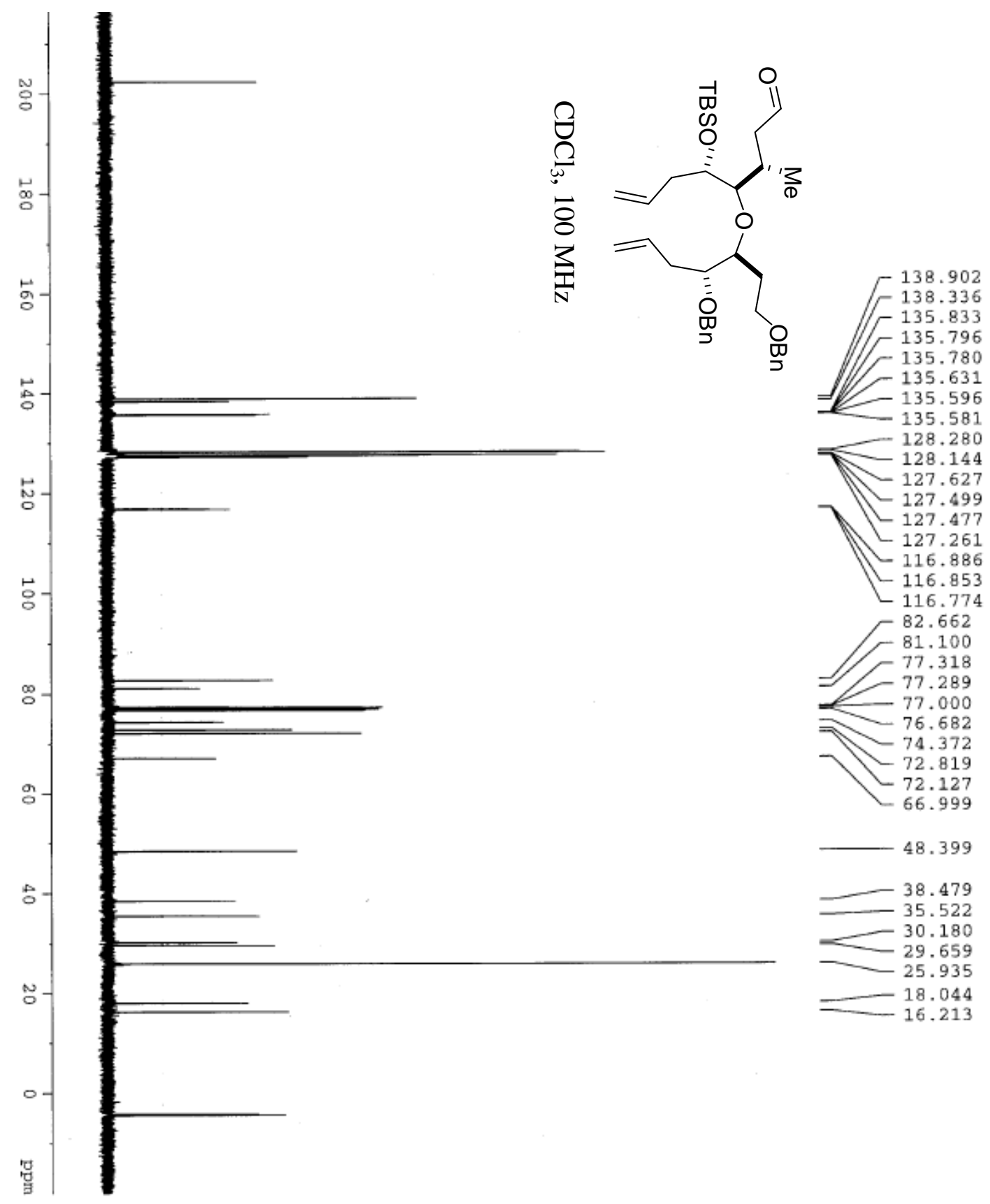




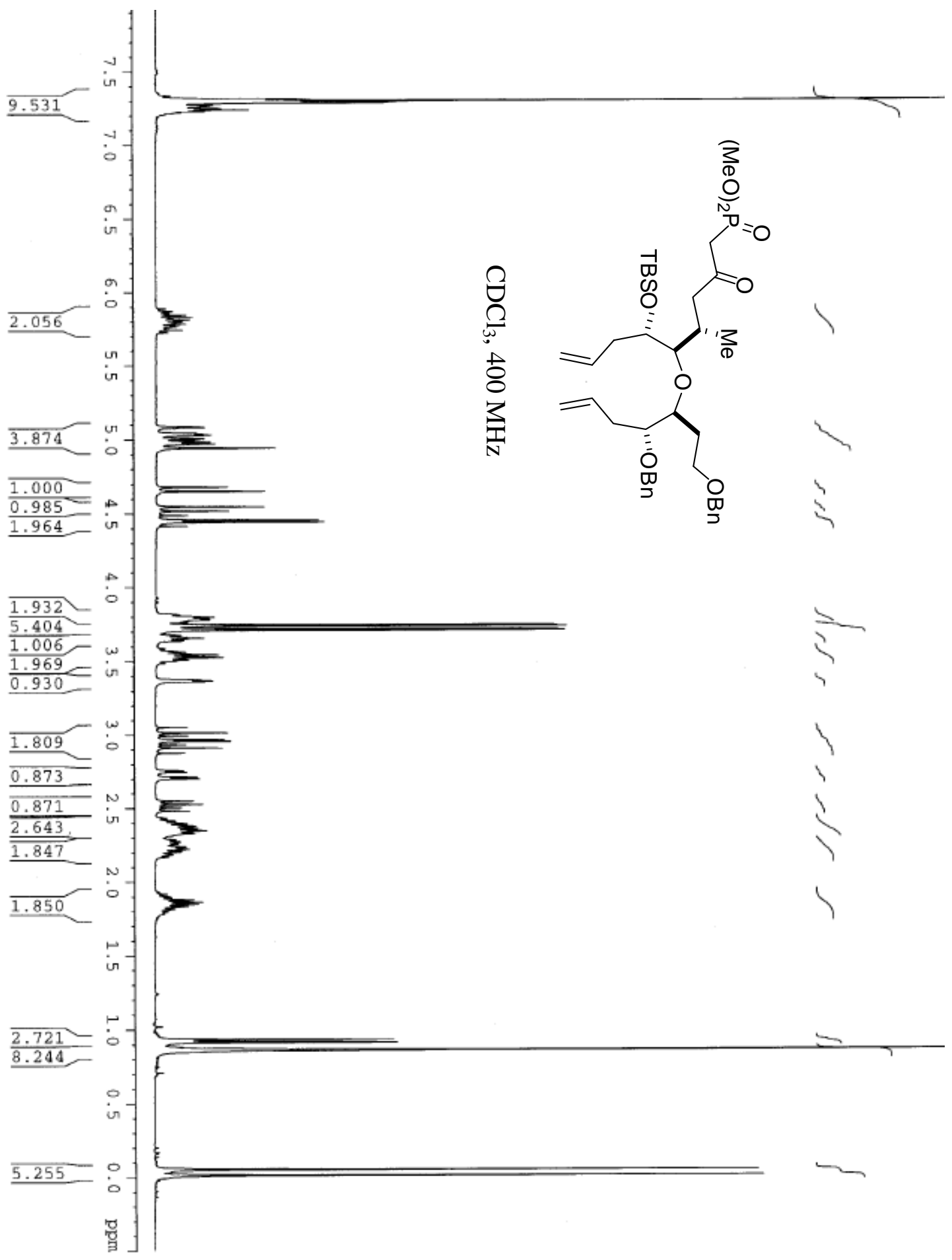



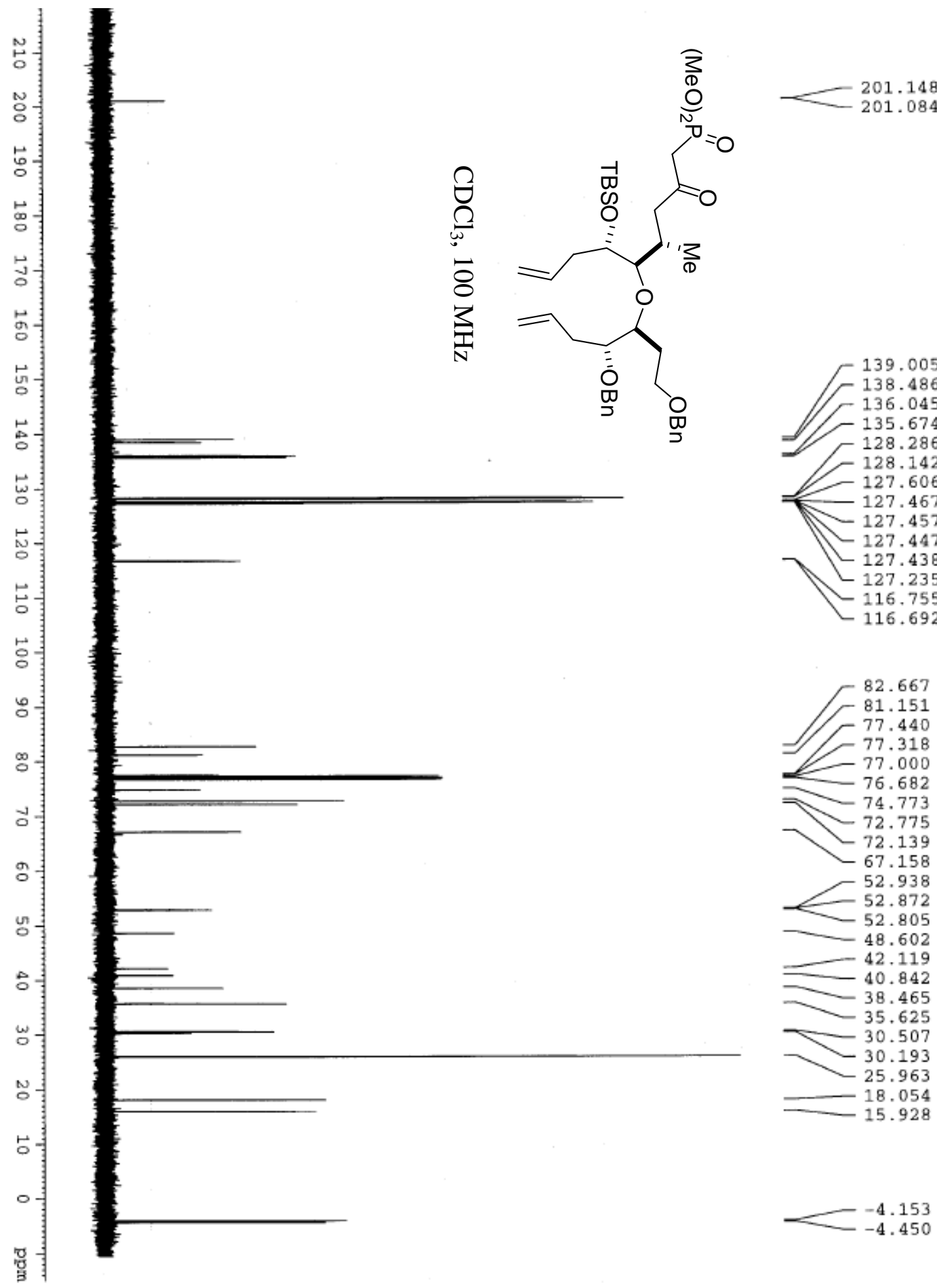
201.148
-201.084
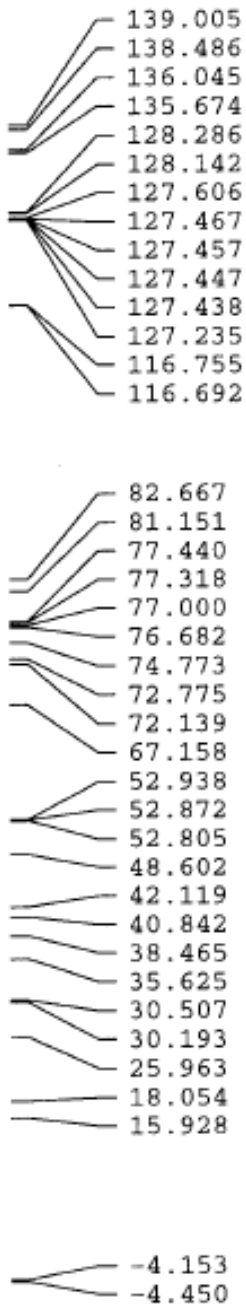


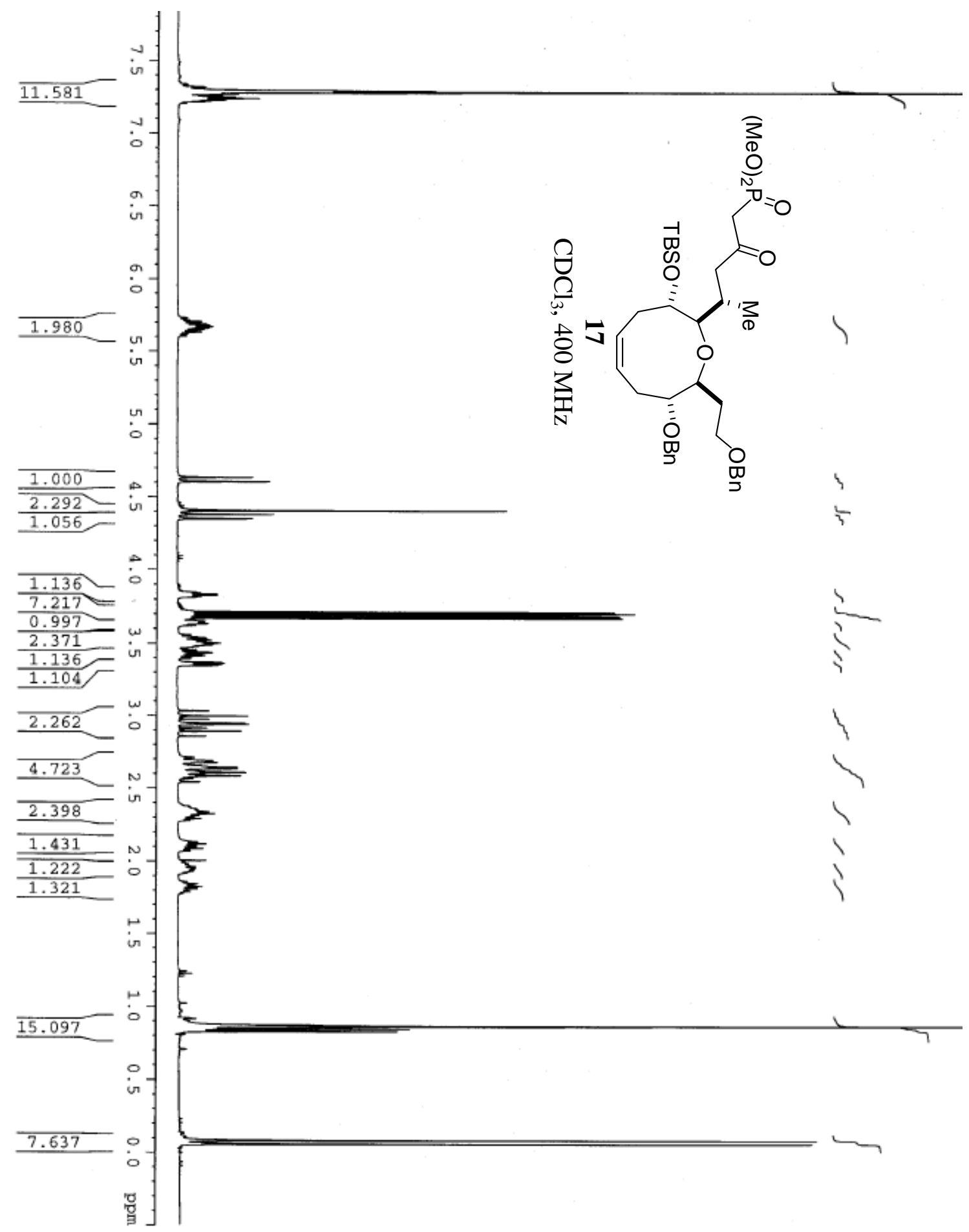



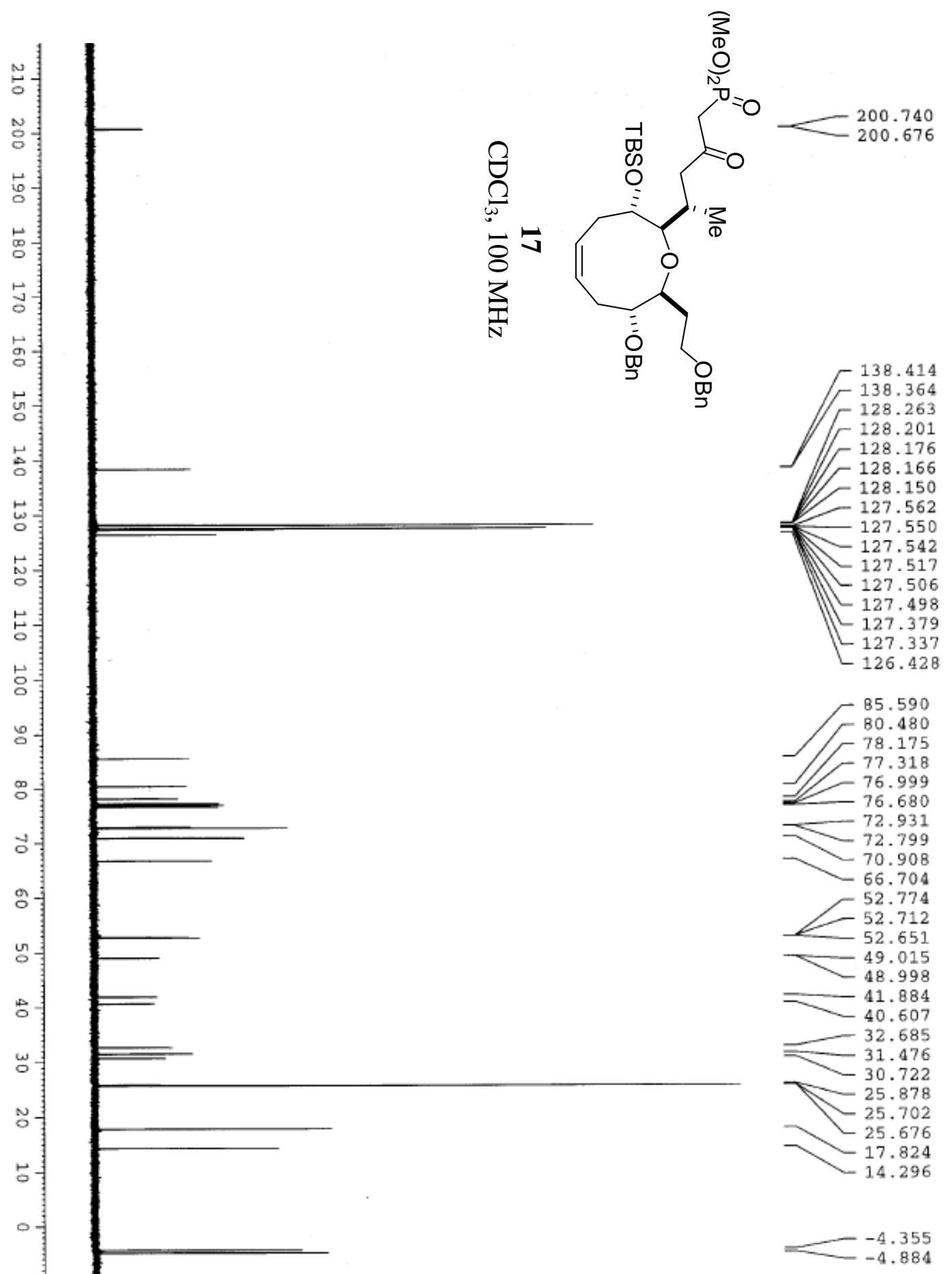


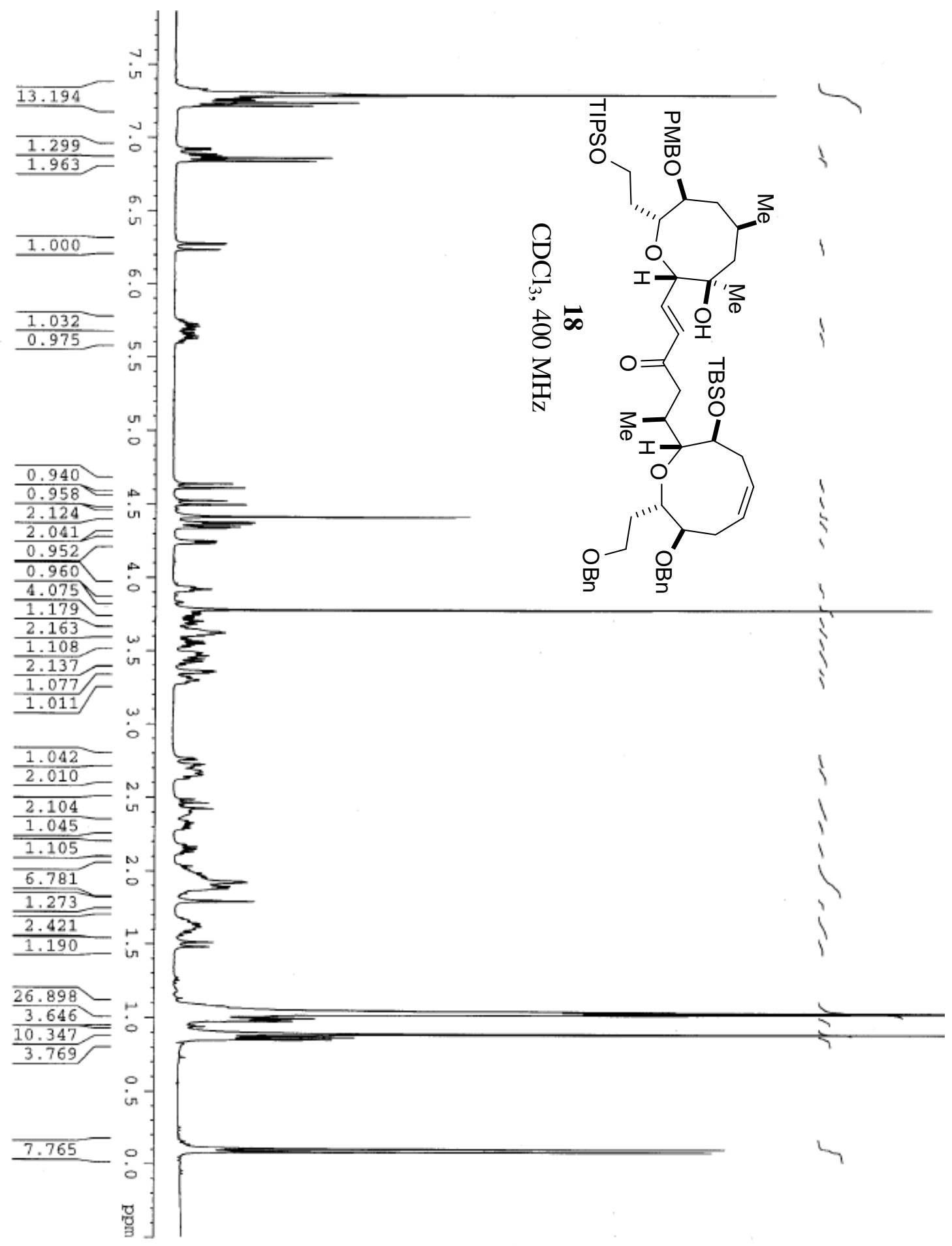




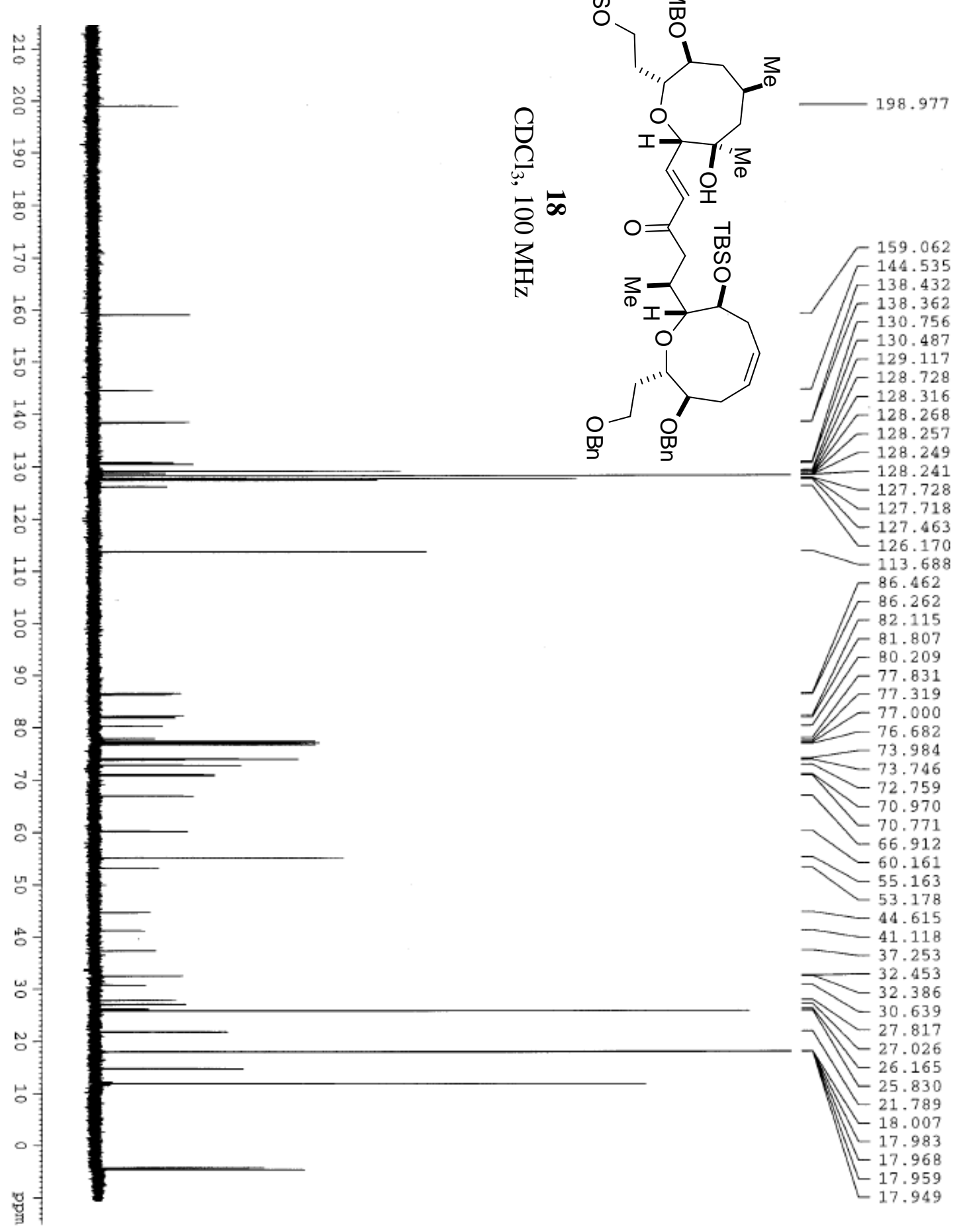




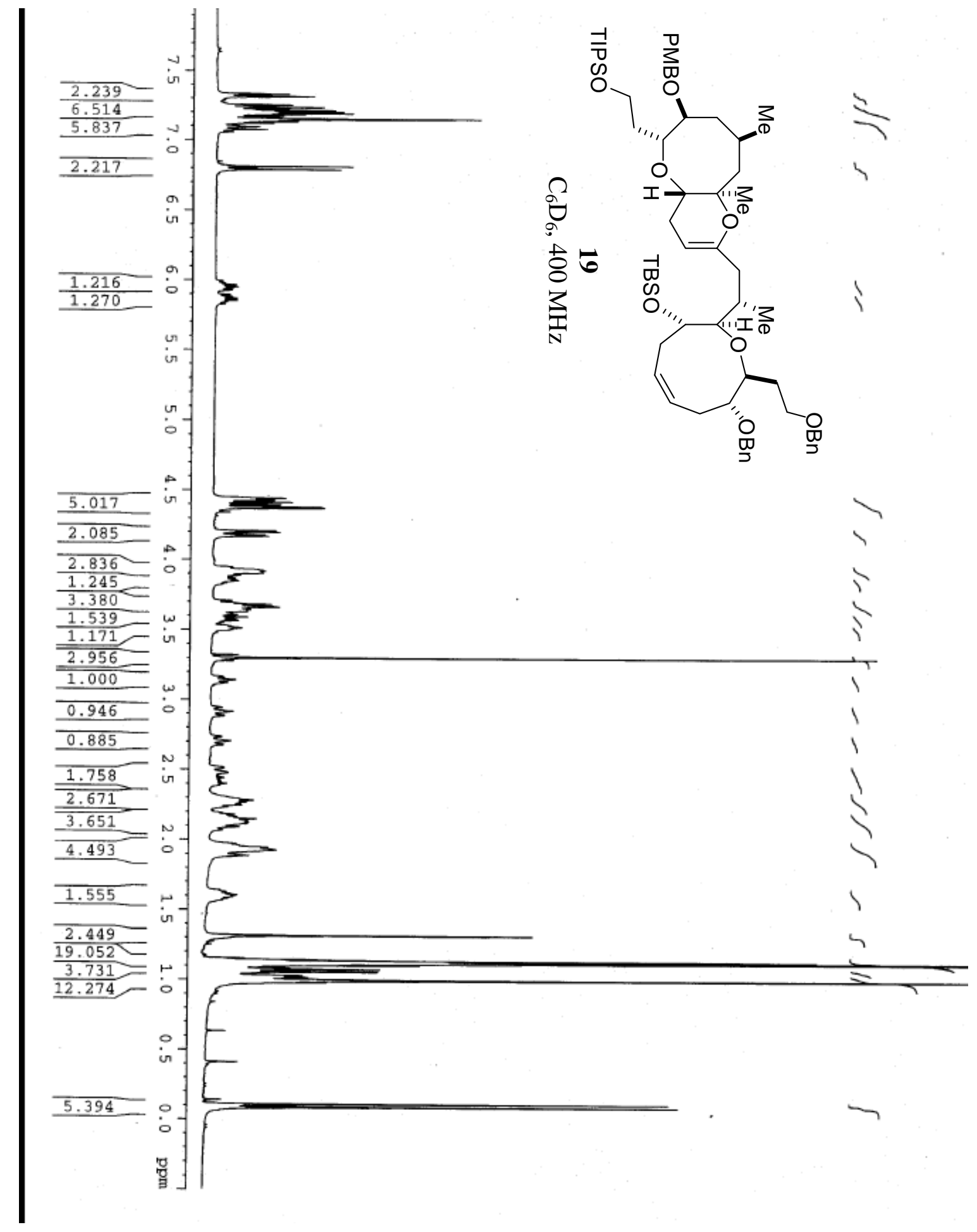




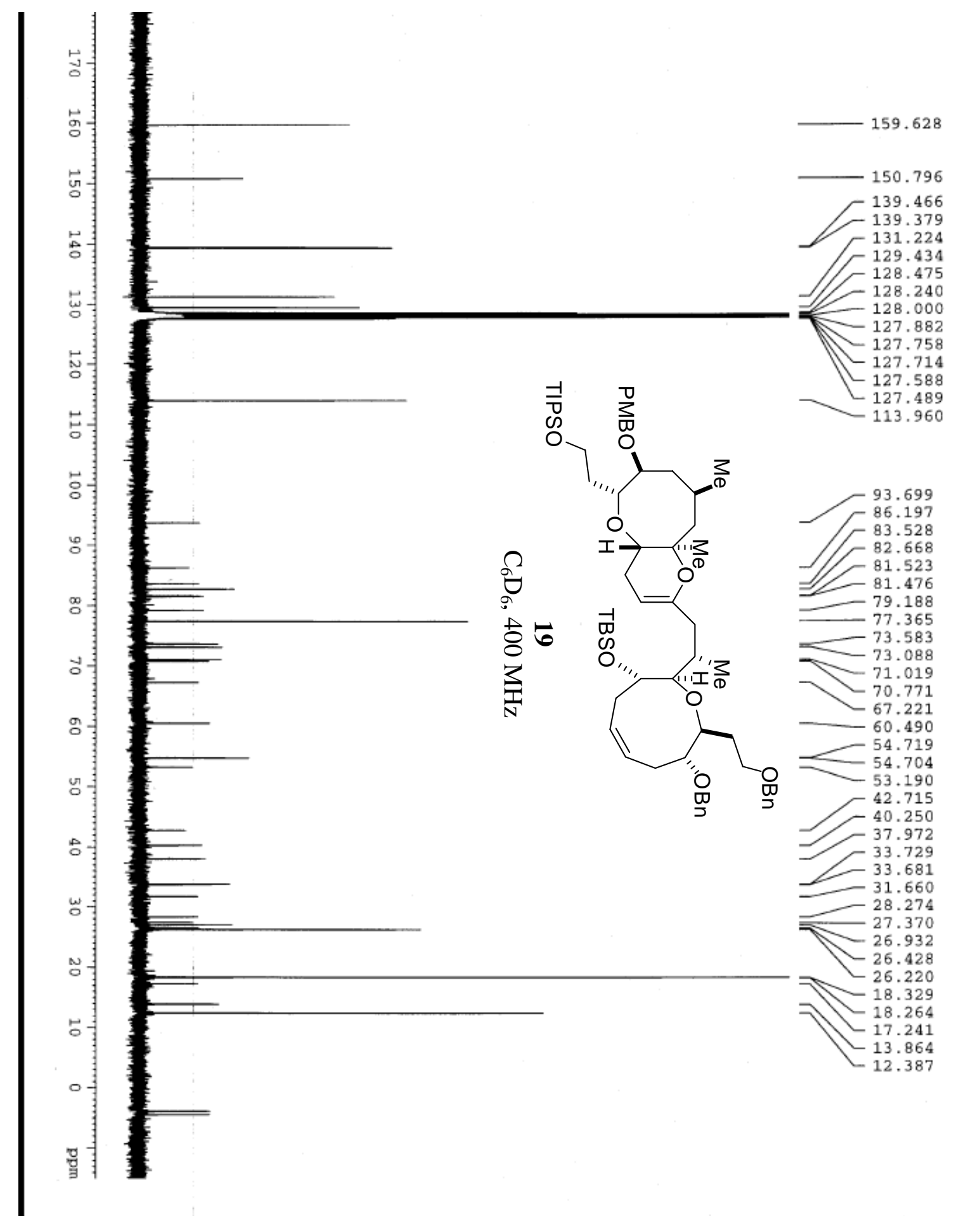




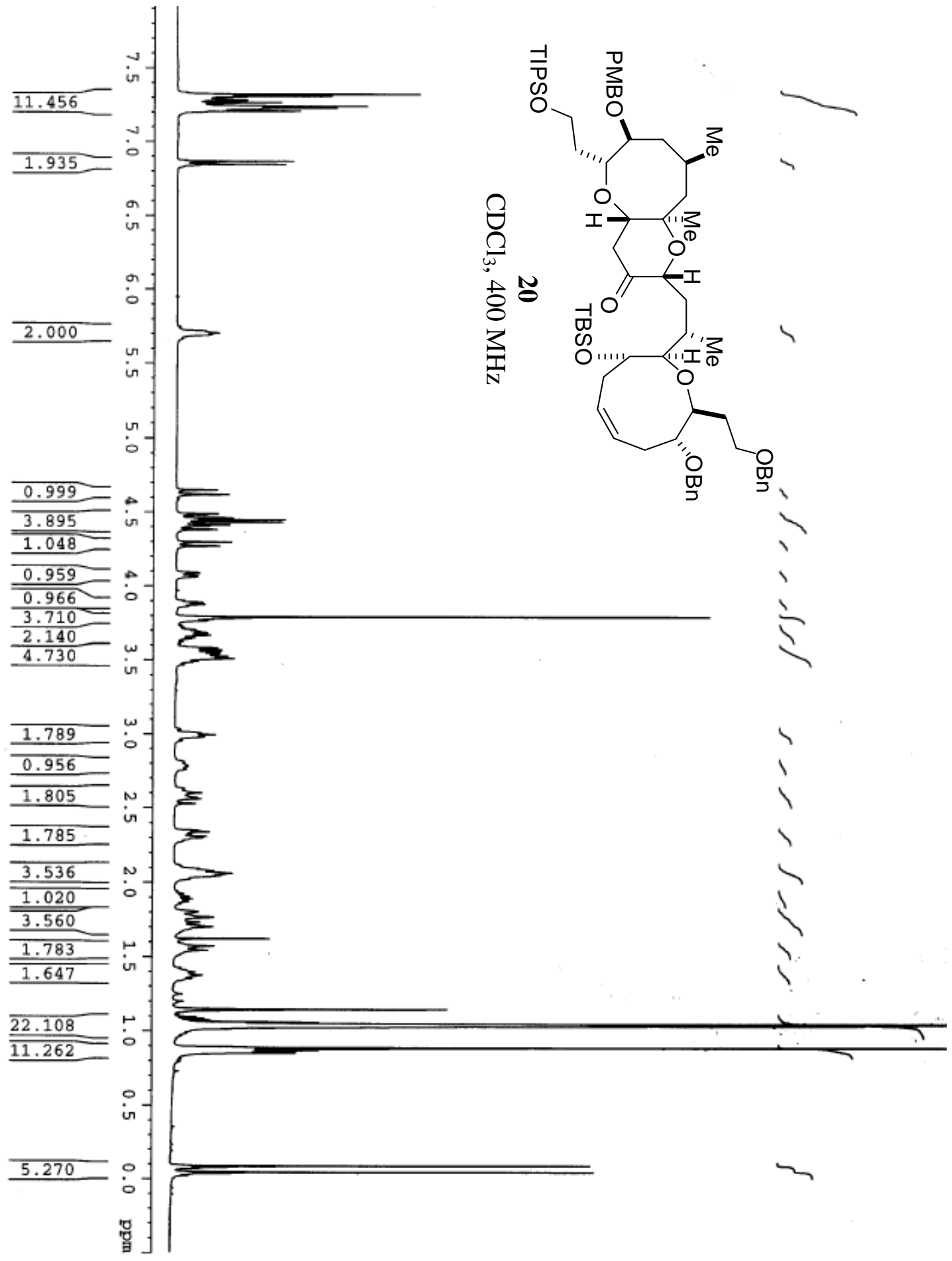




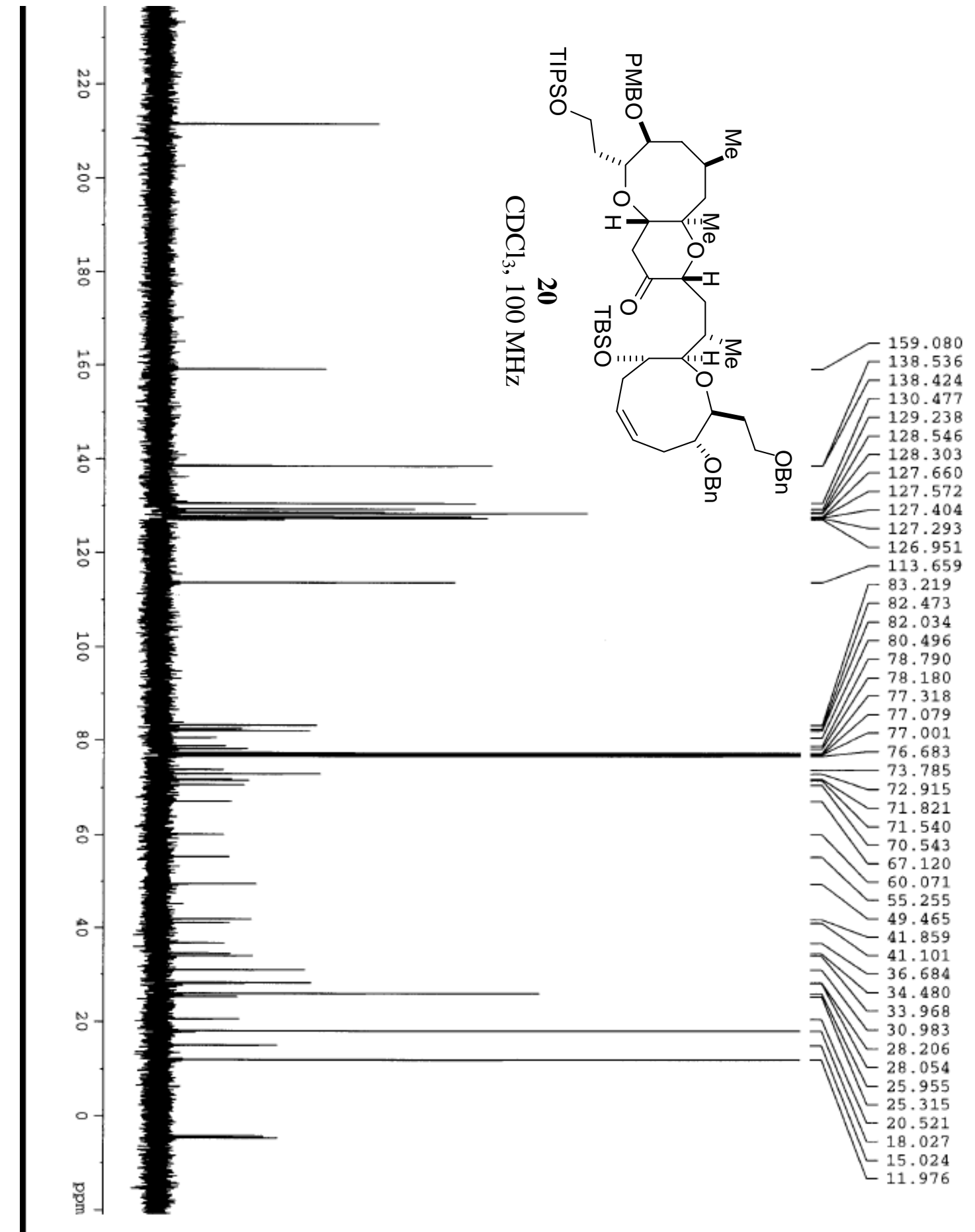




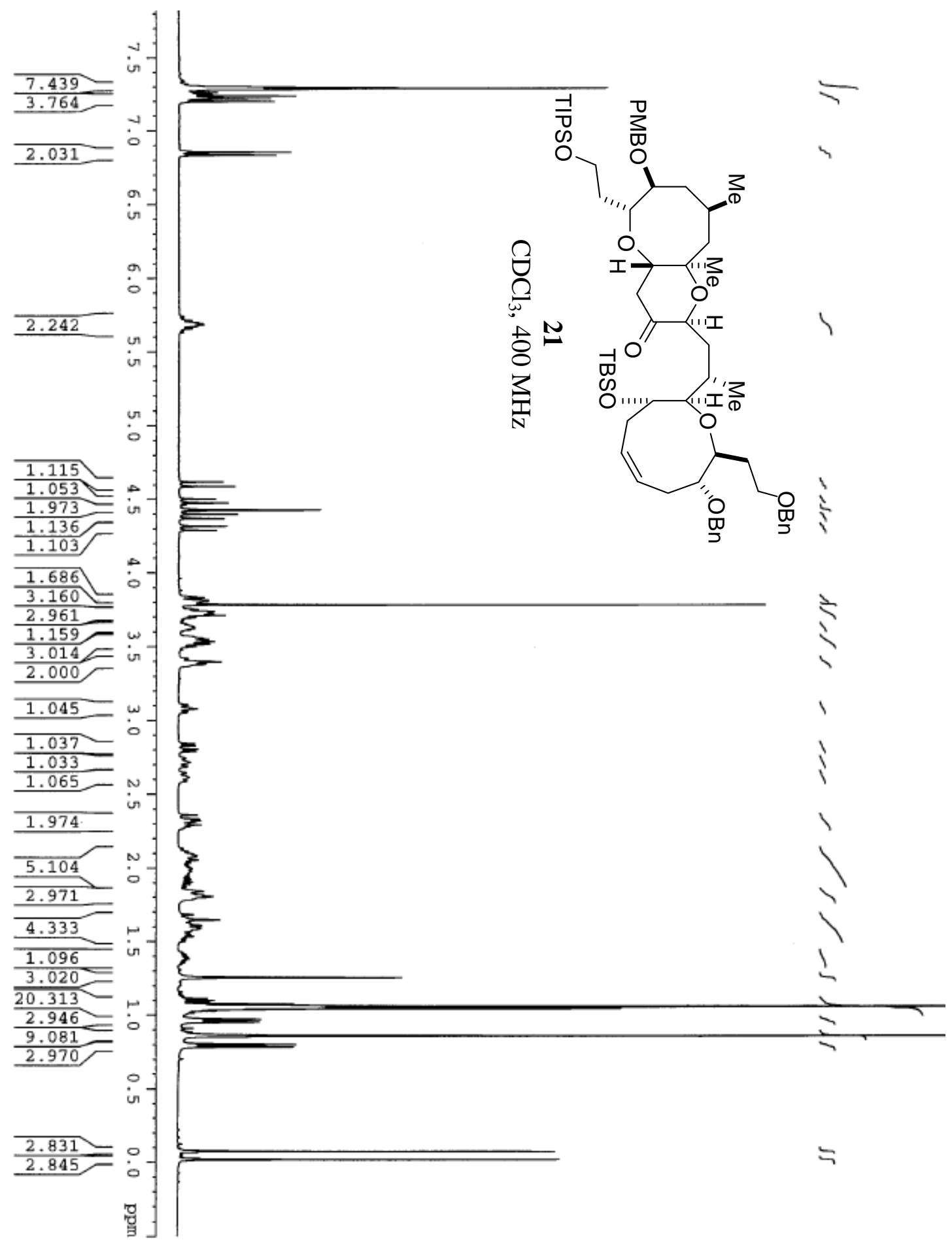



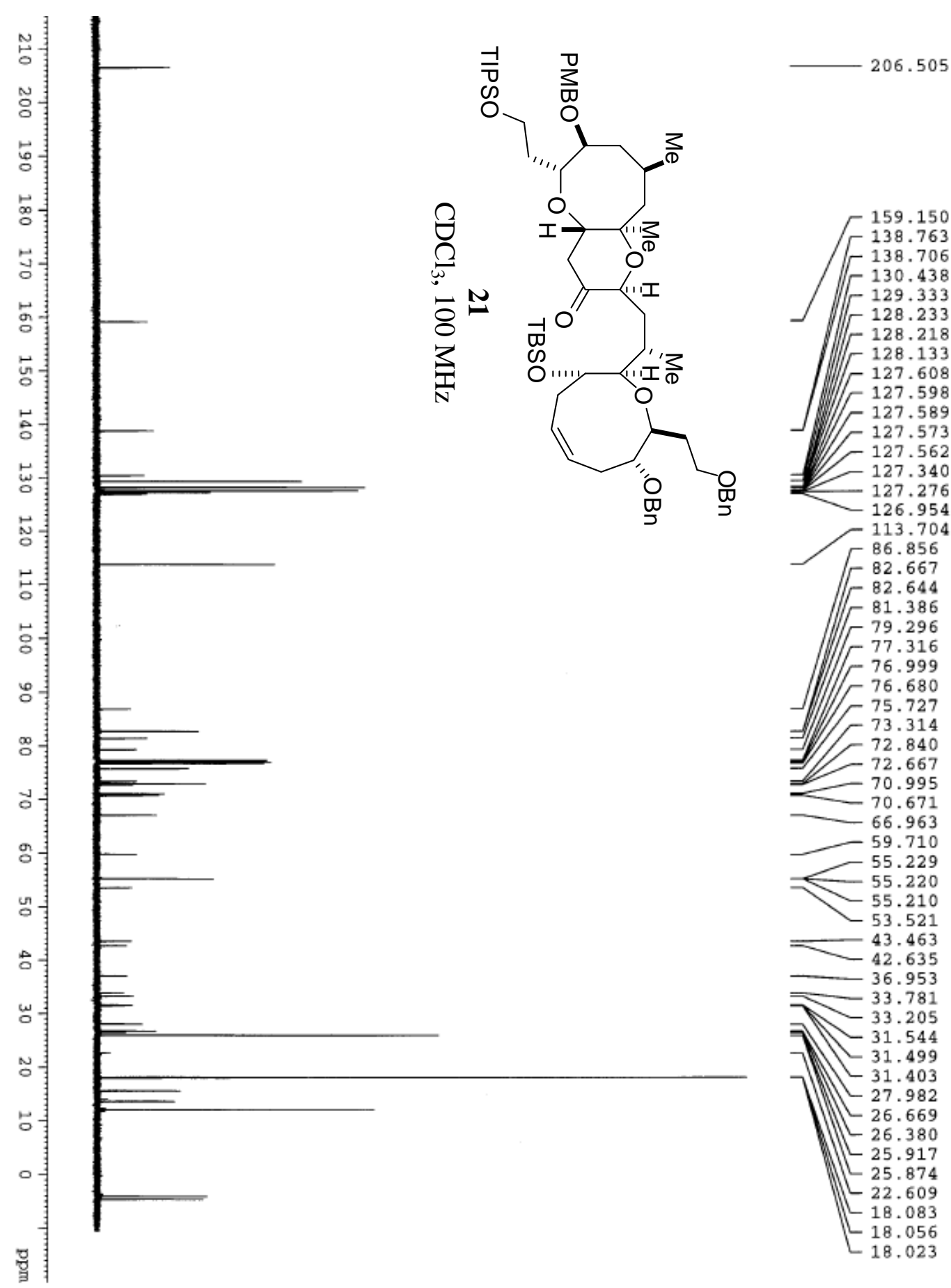


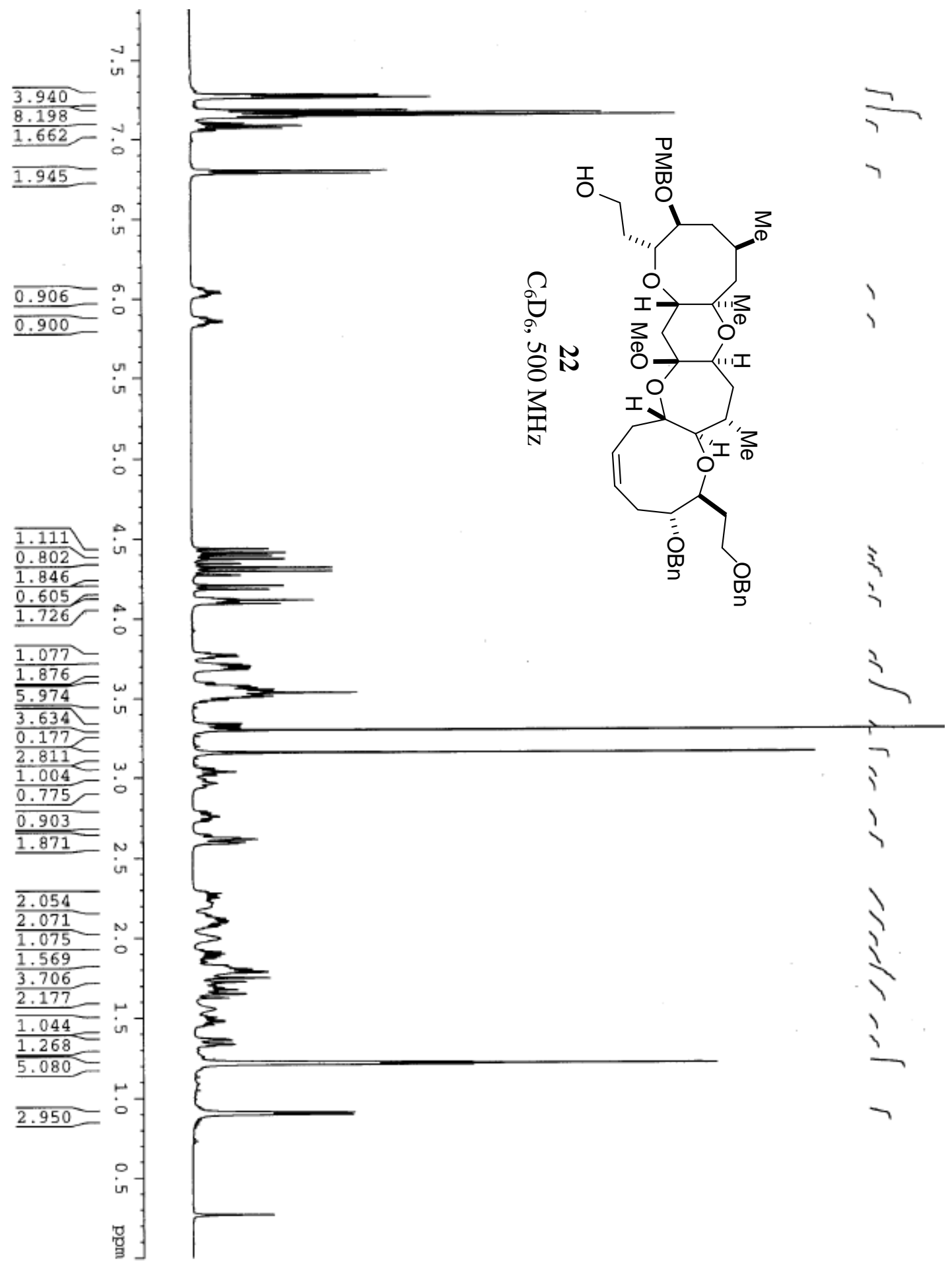




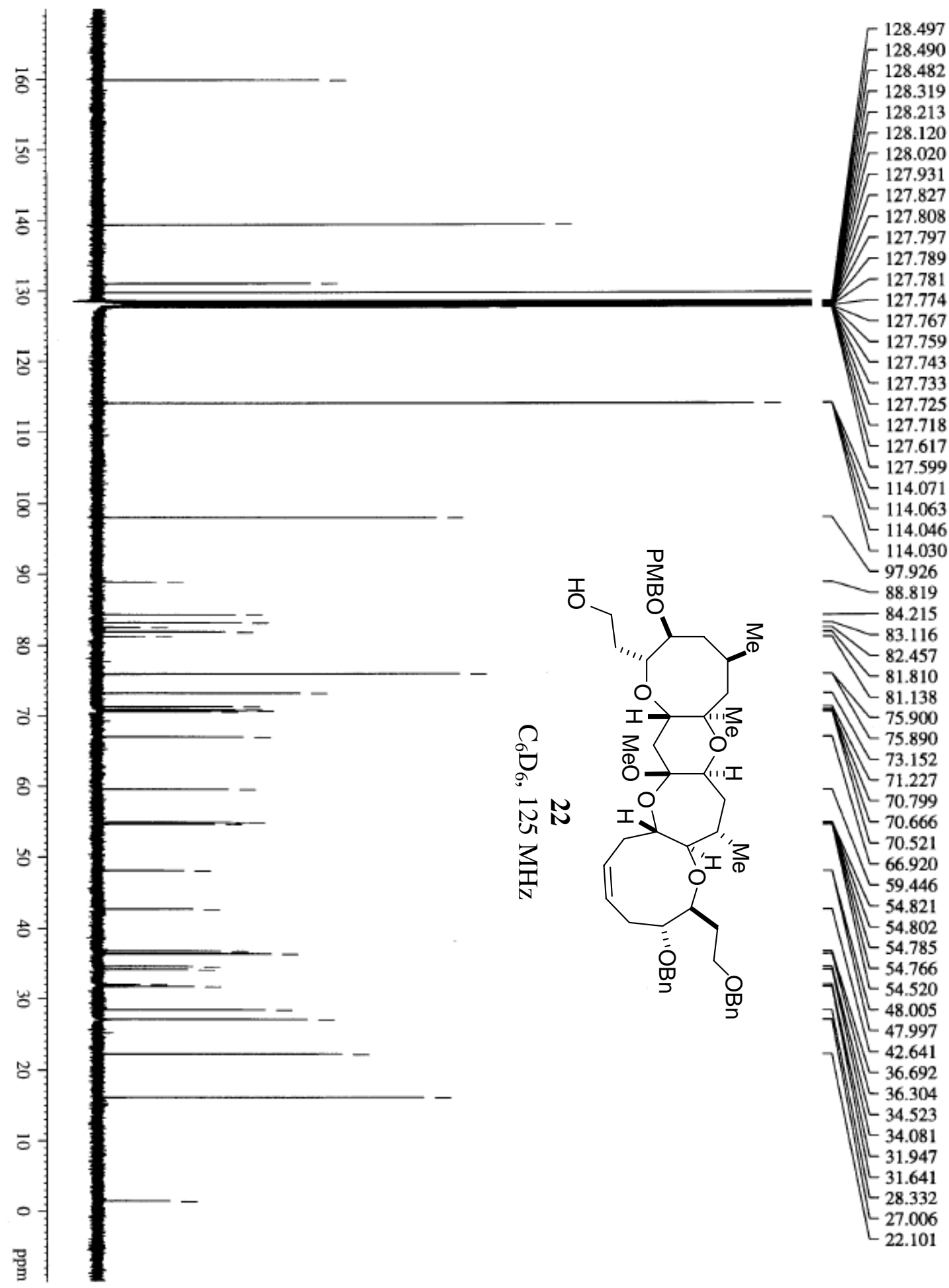




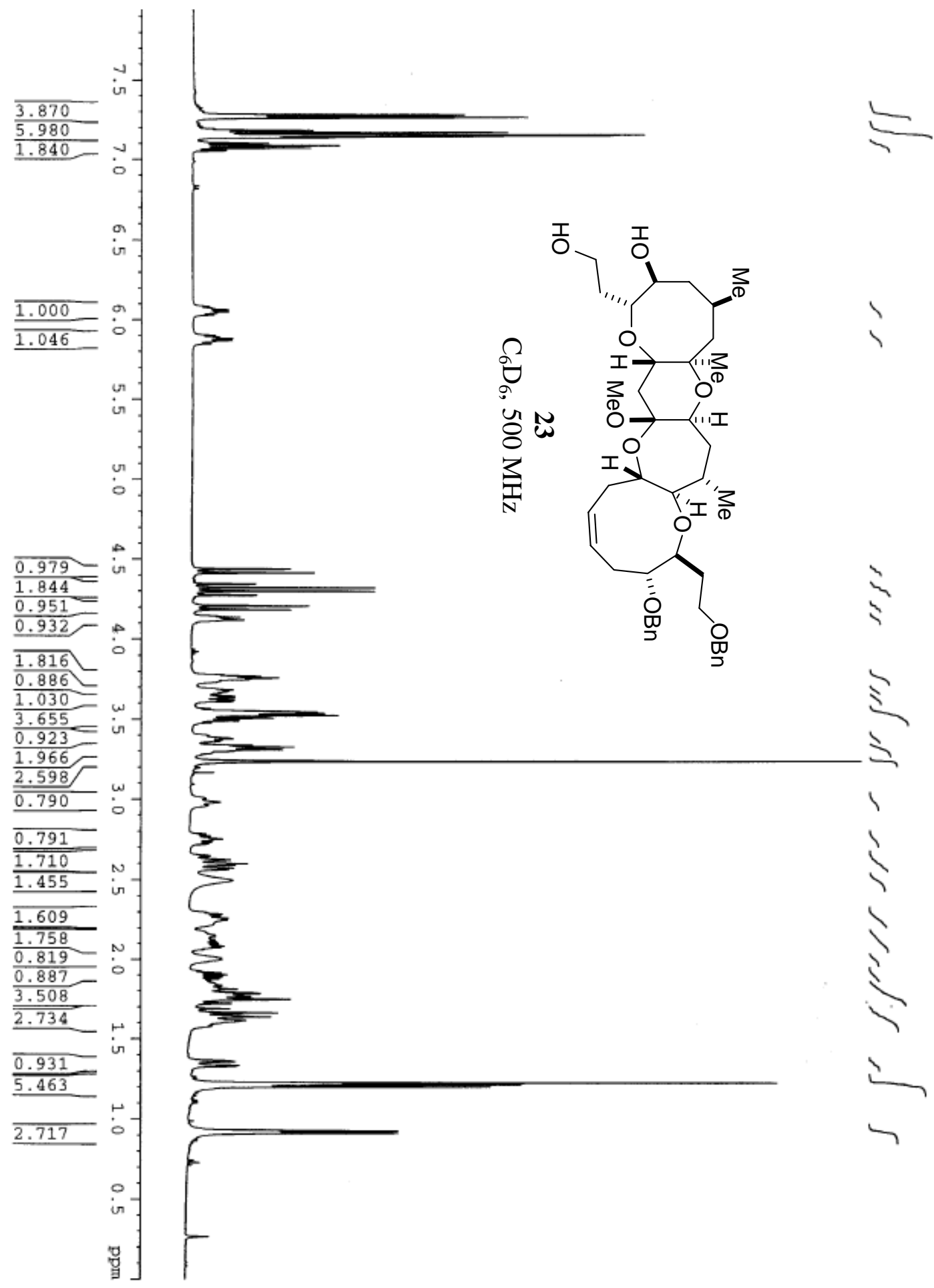




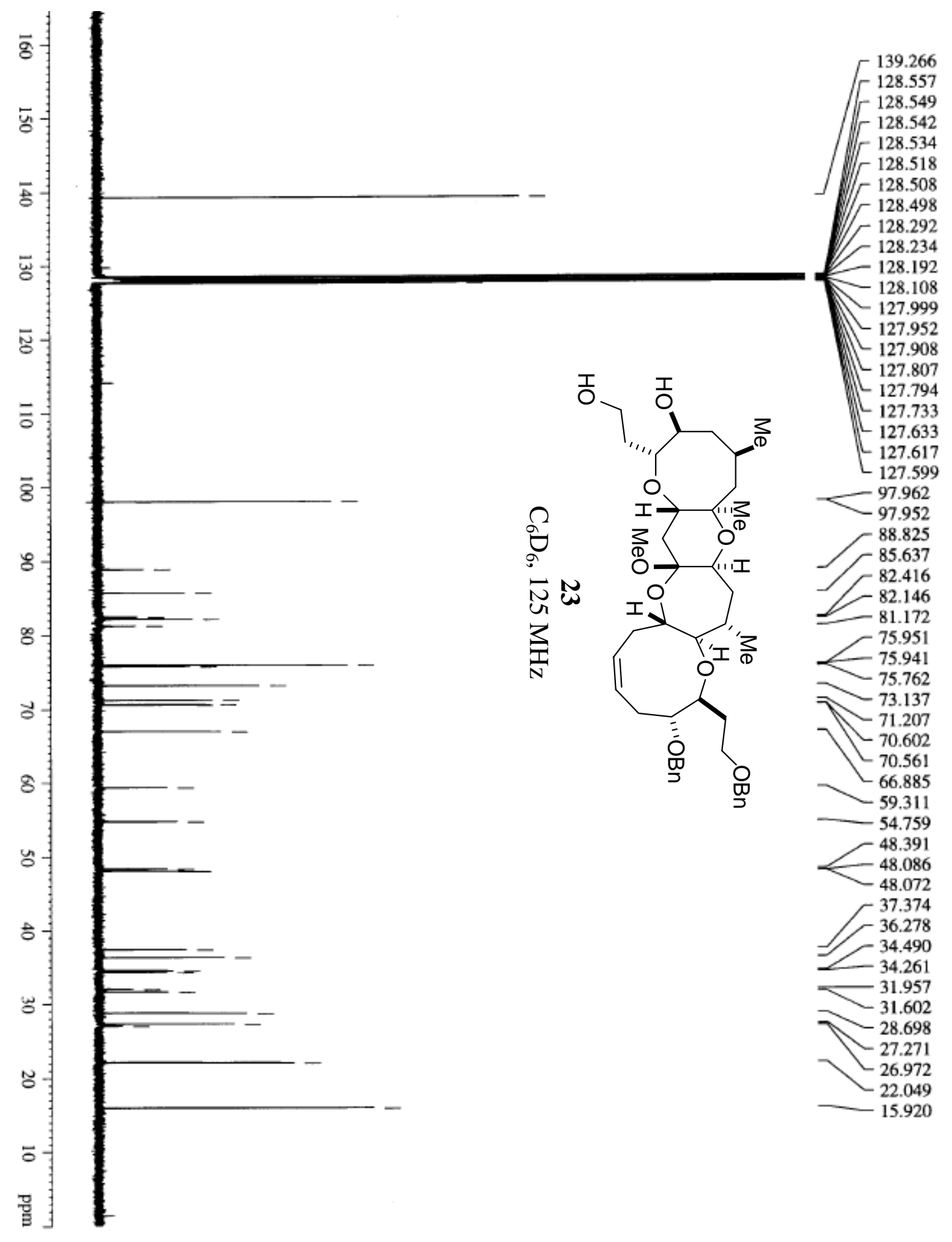




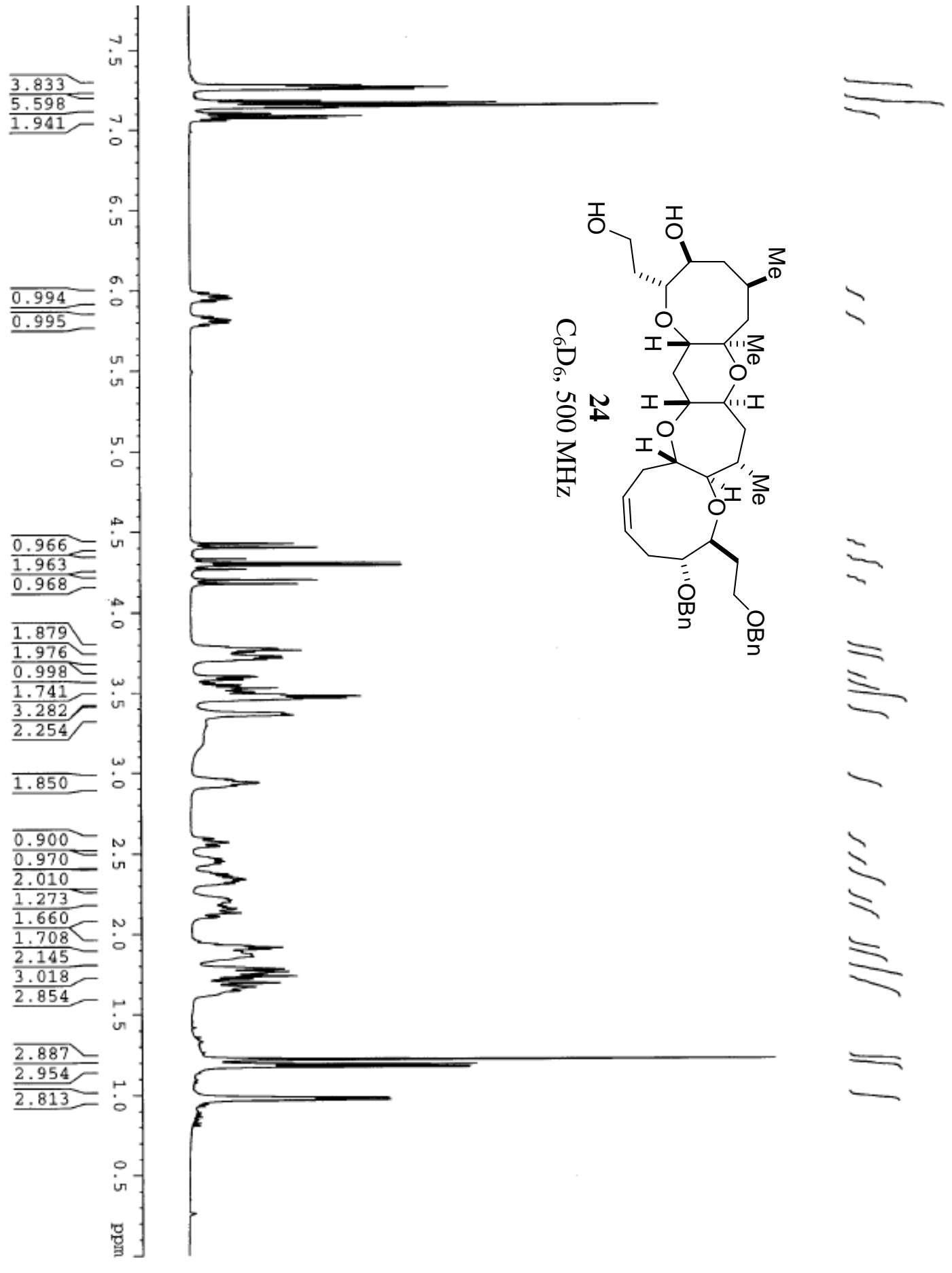




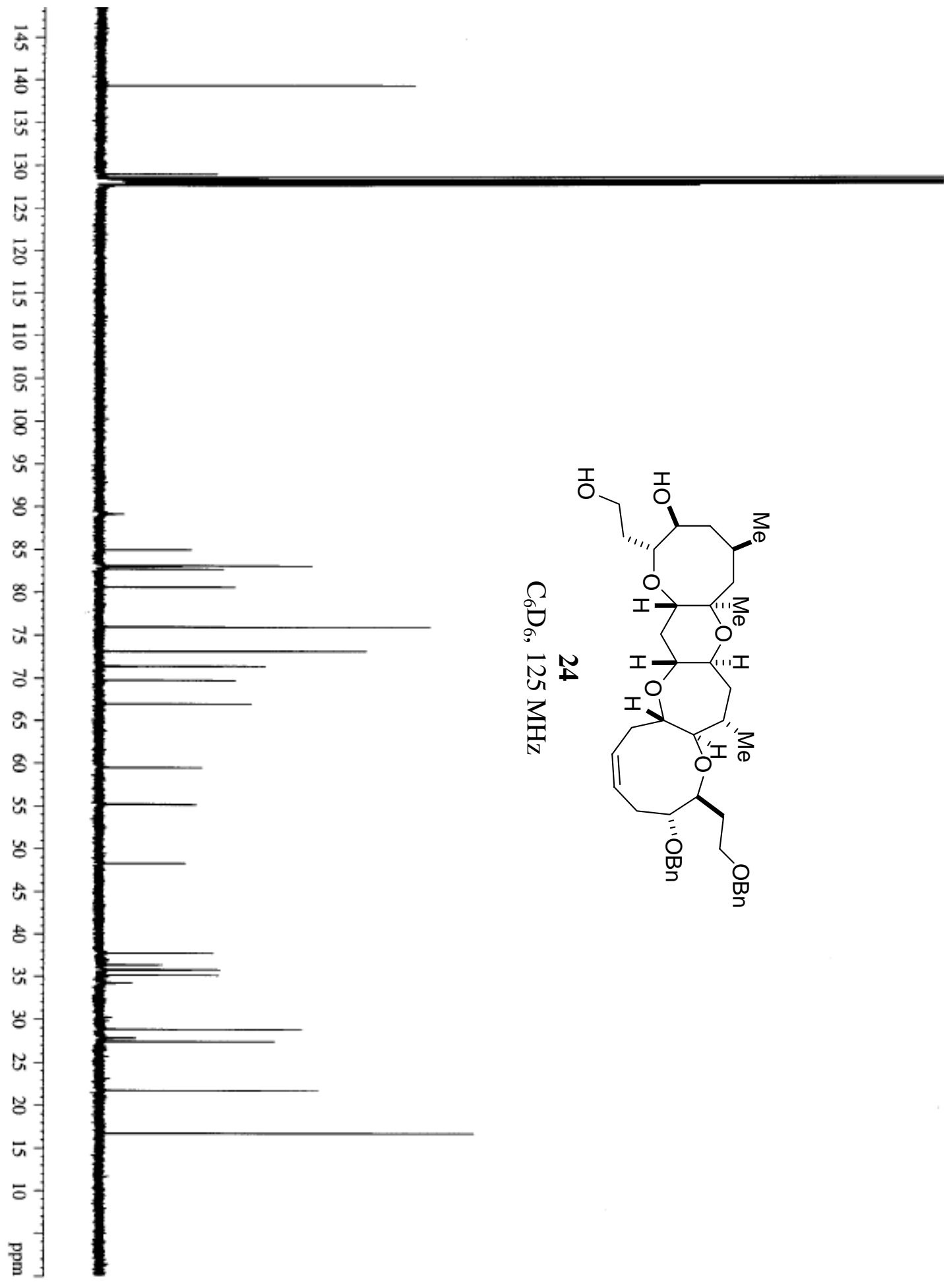




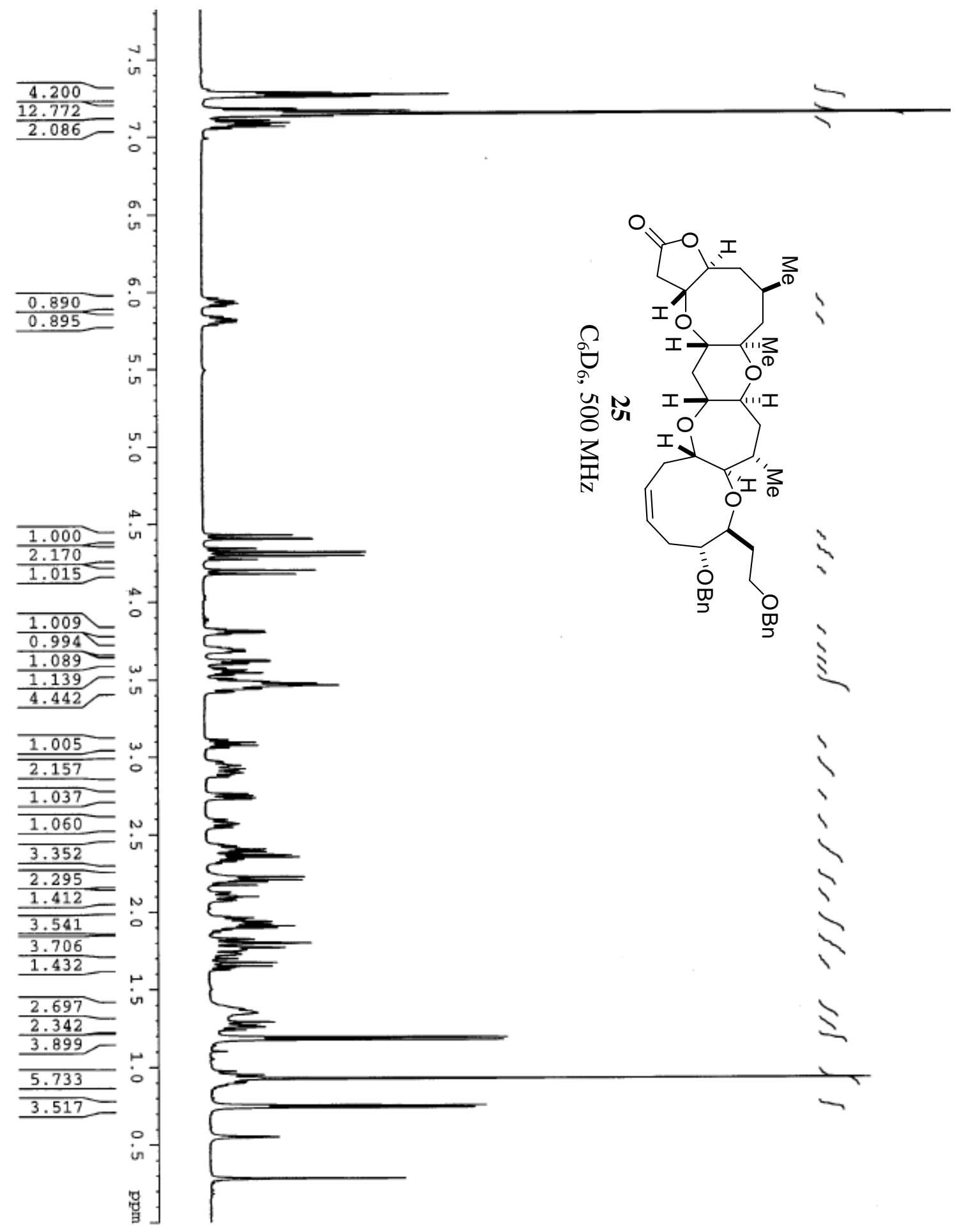




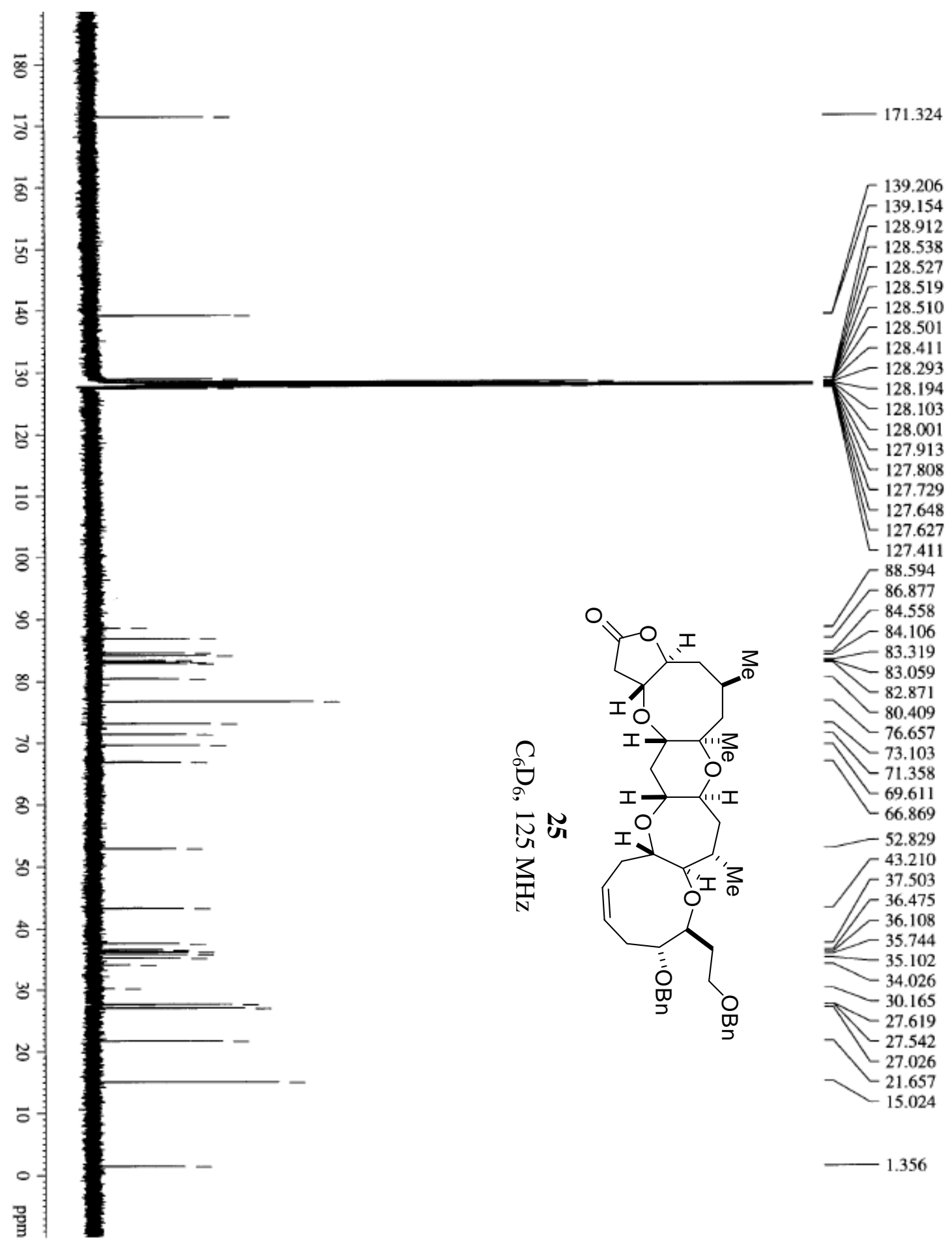




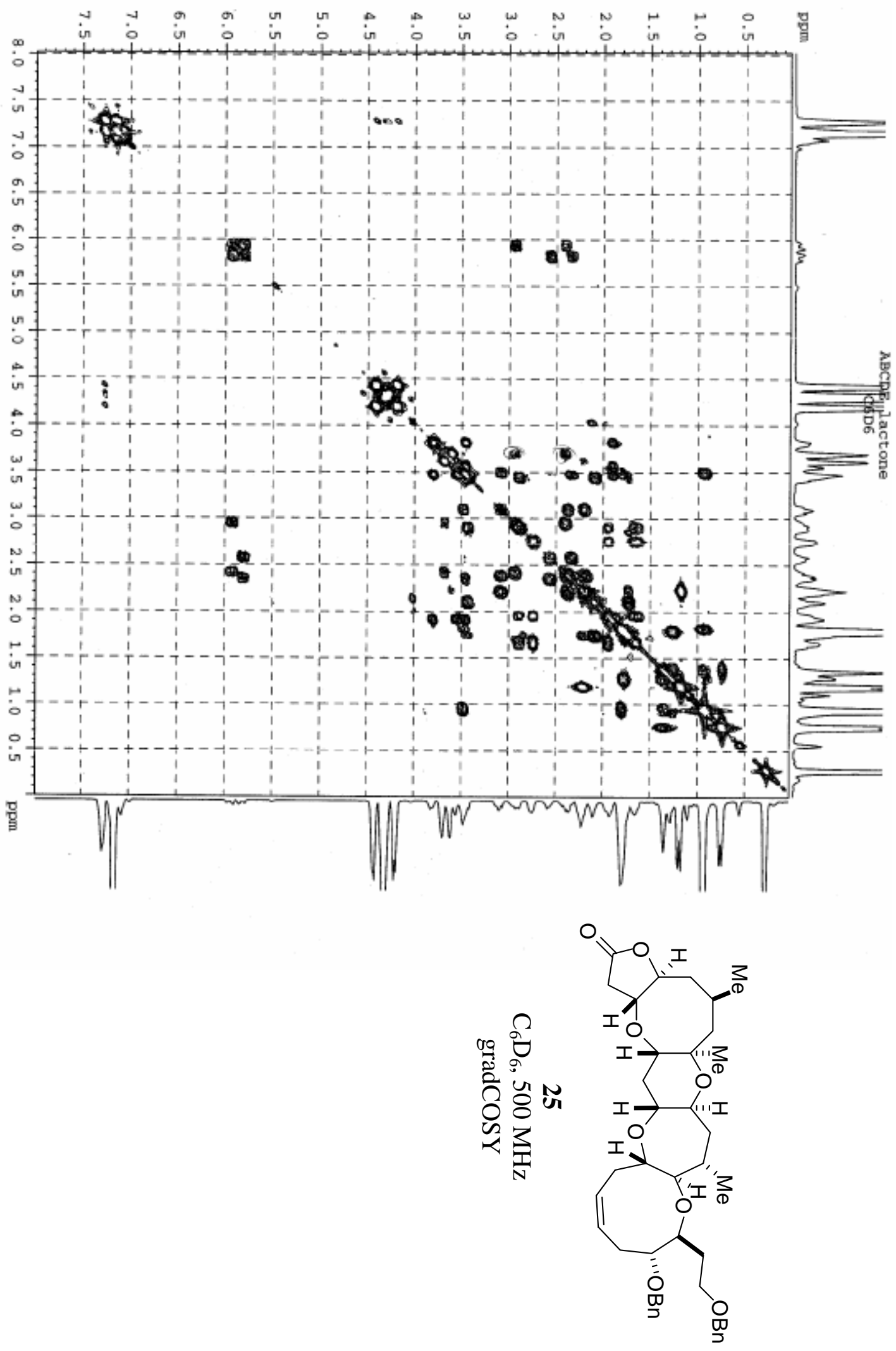




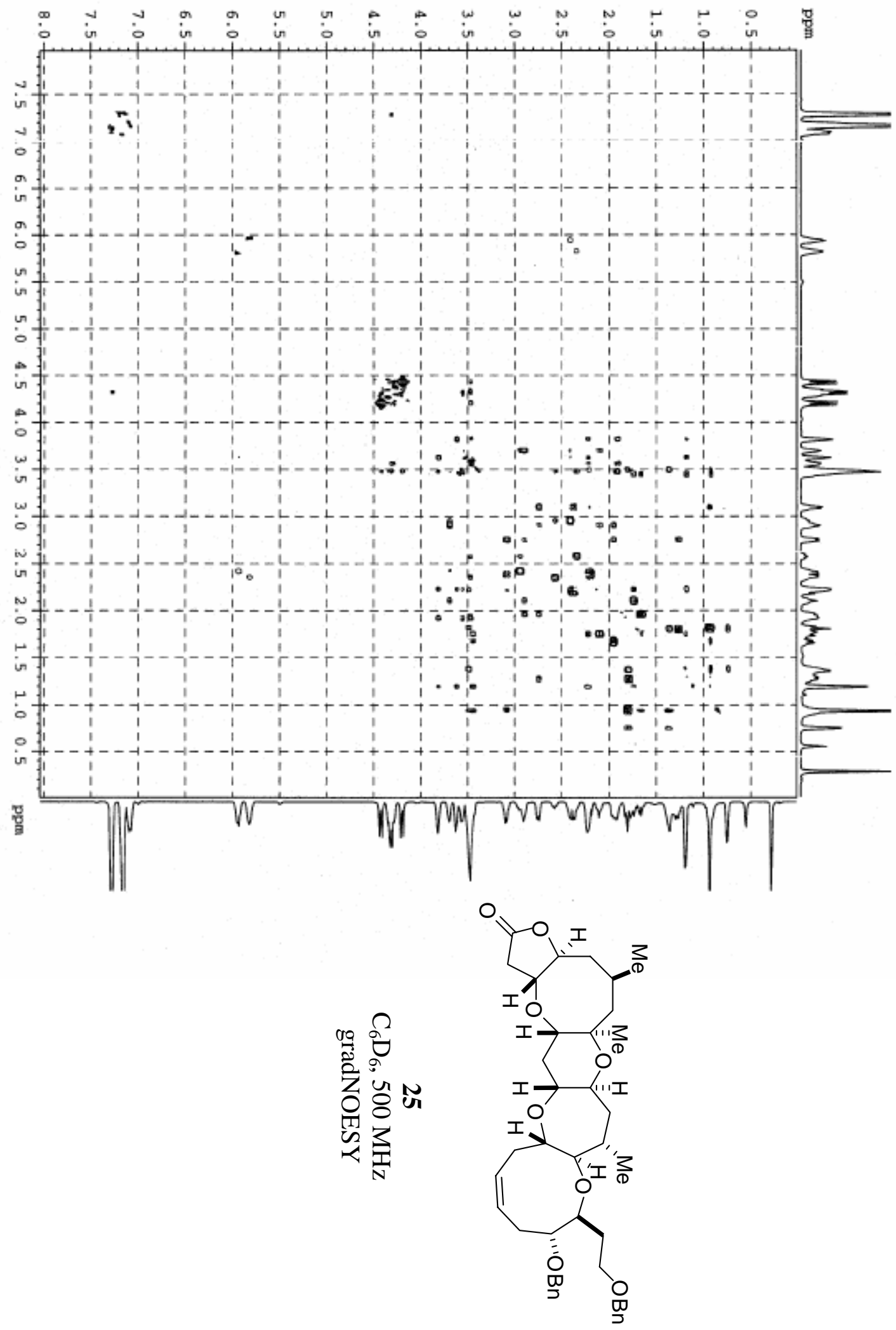

